Universidade Federal da Bahia

Instituto de Ciências da Saúde

Volume 20 - N. 1

Suplemento 1

\title{
Revista de Ciências Médicas e Biológicas
}

Journal of Medical and Biological Sciences

\section{UNIVERSIDADE FEDERAL DA BAHIA}

INSTITUTO DE CIÊNCIAS DA SAÚDE

PROGRAMA DE PÓS-GRADUAÇÃO EM IMUNOLOGIA

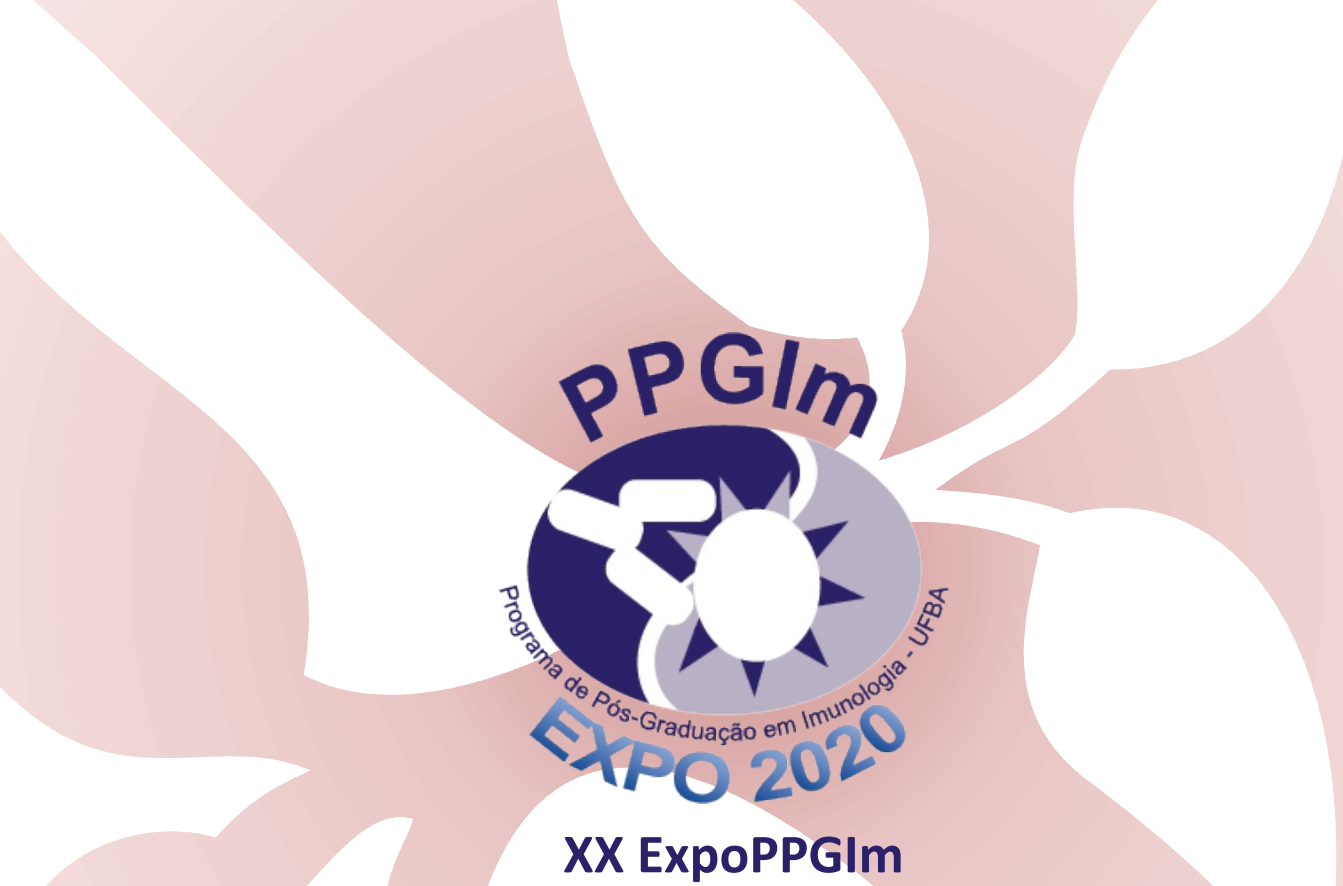

Reunião Anual do Programa de Pós-graduação em Imunologia RESUMOS

1 a 5 de setembro de 2020 


\section{REVISTA DE CIÊNCIAS MÉDICAS E BIOLÓGICAS}

\section{EDITOR CIENTÍFICO / SCIENTIFIC EDITOR}

Roberto Paulo Correia de Araújo

Universidade Federal da Bahia - UFBA, Brasil

\section{EDITOR ASSOCIADO}

Maria Thereza Barral Araújo

Universidade Federal da Bahia - UFBA, Brasil

\section{COMISSÃO DE PUBLICAÇÃO}

Luiz Cláudio A. Madureira

Universidade Federal da Bahia - UFBA, Brasil

Max José Pimenta Lima

Universidade Federal da Bahia - UFBA, Brasil

Roberto José Meyer Nascimento

Universidade Federal da Bahia - UFBA, Brasil

\section{COMISSÃO DE ÉTICA}

Antonio Fernando Pereira Falcão

Universidade Federal da Bahia - UFBA, Brasil

Gabriela Botelho Martins

Universidade Federal da Bahia - UFBA, Brasil

Lília F. de Moura Costa

Universidade Federal da Bahia - UFBA, Brasil

Regina Cerqueira Cruz

Universidade Federal da Bahia - UFBA, Brasil

Silvia Inês Sardi

Universidade Federal da Bahia - UFBA, Brasil

\section{CONSELHO EDITORIAL NACIONAL}

\section{Ájax Mercês Atta}

Universidade Federal da Bahia - UFBA, Brasil

Alda Christina Lopes de Carvalho Borges

Universidade Federal da São Paulo - UNIFESP, Brasil Alan Lane de Melo

Universidade Federal de Minas Gerais - UFMG, Brasil Ana Marlúcia Oliveira Assis

Universidade Federal da Bahia - UFBA, Brasil

Antonio Luiz Barbosa Pinheiro

Universidade Federal da Bahia - UFBA, Brasil

Áureo Tatsumi Yamada

Universidade Estadual de Campinas - Unicamp, Brasil Aryon de Almeida Barbosa Junior

FIOCRUZ-BA. Centro de Pesquisa Gonçalo Muniz, Brasil

Cláudio Roberto Madruga

Empresa Brasileira de Pesquisa Agropecuária - EMBRAPA, Brasil

Carlos Marcelo da Silva Figueiredo

Universidade do Estado do Rio de Janeiro - UERJ, Brasil

Edivaldo Ximenes Ferreira Filho

Universidade de Brasilia - UnB, Brasil

Eliane Elisa de Souza Azevedo

Universidade Federal da Bahia - UFBA, Brasil

Flávio Fava de Moraes

Universidade de São Paulo - USP, Brasi

Frab Norberto Bóscolo

Universidade Estadual de Campinas - UNICAMP, Brasil

Isaac Suzart Gomes Filho

Universidade Estadual de Feira de Santana - UEFS, Brasil

Irene Queiroz Markezan

Centro de Especialização em Fonoaudiologia Clínica - CEFAC, Brasil Jairnilson Silva Paim

Universidade Federal da Bahia - UFBA, Brasil

José Henrique Rubo

Universidade de São Paulo - USP, Brasil

José Tavares Neto

Universidade Federal da Bahia - UFBA, Brasil

Josicelia Dumêt Fernandes

Universidade Federal da Bahia - UFBA, Brasil

Mara Suzana Behlau

Centro do Estudo da Voz - CEV, Brasil

Maria Cecília Martinelli lório

Universidade Federal da São Paulo - UNIFESP, Brasil

Maria Fidela de Lima Navarro

Universidade de São Paulo - USP, Brasi

Maria Thereza Barral Araújo

Universidade Federal da Bahia - UFBA, Brasil
Marlene Campos Pese de Aguiar

Universidade Federal da Bahia - UFBA, Brasil

Mauricio Lima Barreto

Universidade Federal da Bahia - UFBA, Brasil

Moacyr Alcoforado Rebello

Universidade Federal do Rio de Janeiro - UFRJ, Brasil

Moyses Sadigursky

Universidade Federal da Bahia - UFBA, Brasil

Paulo Sérgio Flores Campos

Universidade Federal da Bahia - UFBA, Brasil

Raymundo Paraná Ferreira Filho

Universidade Federal da Bahia - UFBA, Brasil

Sérgio Costa Oliveira

Universidade Federal de Minas Gerais - UFMG, Brasil

Telmo Bandeira Berthold

Pontifícia Universidade Católica do Rio Grande do Sul - PUCRS, Brasil

Vasco Ariston de Carvalho Azevedo

Universidade Federal de Minas Gerais - UFMG, Brasil

Victor E. Arana Chaves

Universidade de São Paulo - USP, Brasil

Walter Colli

Universidade de São Paulo - USP, Brasil

CONSELHO EDITORIAL INTERNACIONAL

Eduardo de Aquino Ximenes

University of lowa

Hugo Famboim

Hospital Nacional de Infecciosas Francisco Muniz, Argentina

Jose La Torre

Universidad de Buenos Aires, Argentina

Gildo Coelho Santos Júnio

Schulich Western, Canada

Júlio Licinio de Castro Paixão

University of Califórnia - UCLA, Estados Unidos da América do Norte

Marcienne Tardy

Université de Paris XI

Mário A. Barbosa

Universidade do Porto, Portugal

Maria Rita Mônica Cufré

Hospital Nacional de Infecciosas Francisco Muniz, Argentina

Rodolfo Hector Campos

Universidad de Bueno Aires, Argentina

\section{CONSELHO AD HOC}

Ailton da Souza Melo

Universidade Federal da Bahia - UFBA, Brasil

Alessandro Leite Calvalcanti

Universidade Estadual da Paraiba - UFPB, Brasil

Ana Maria Toniolo da Silva

Universidade Federal de Santa Maria - UFSM, Brasi

Celma Borges Gomes

Universidade Federal da Bahia - UFBA, Brasil

Danilo Barral de Araujo

Universidade Federal da Bahia - UFBA, Brasil

Edmar José Borges Santana

Faculdade Maria Milza - FAMAM, Brasil

Eneida de Moraes Marcílio Cerqueira

Universidade Estadual de Feira de Santana - UEFS, Brasil

Elisângela de Jesus Campos

Universidade Federal da Bahia - UFBA, Brasil

Irismar Reis de Oliveira

Universidade Federal da Bahia - UFBA, Brasil

José Bento Alves

Universidade de Uberaba, Brasil

Luciana Rodrigues Silva

Universidade Federal da Bahia - UFBA, Brasi

Marcos André Vannier dos Santos

FIOCRUZ-BA. Centro de Pesquisa Gonçalo Muniz, Brasil

Maria Celina Barreiros Siquara da Rocha

Fundação Bahiana para o Desenvolvimento das Ciências - FBDC, Brasil

Maria da Pureza Spínola Miranda

Universidade Federal da Bahia - UFBA, Brasil

Maria Rita Mônica Cufré

Hospital Nacional de Infecciosas Francisco Muniz, Argentina

Rogéria Comastri de Castro Almeida

Universidade Federal da Bahia - UFBA, Brasil

Silvio José Albergaria da Silva

Universidade Federal da Bahia - UFBA, Brasi

Telma Martins de Araújo

Universidade Federal da Bahia - UFBA, Brasil

Urbino da Rocha Tunes

Fundação Bahiana para o Desenvolvimento das Ciências - FBDC, Brasil Zelita Caldeira Ferreira Guedes

Universidade de São Paulo - USP, Brasil

www.cienciasmedicasbiologicas.ufba.br 


\title{
UNIVERSIDADE FEDERAL DA BAHIA
}

\author{
INSTITUTO DE CIÊNCIAS DA SAÚDE \\ PROGRAMA DE PÓS-GRADUAÇÃO EM IMUNOLOGIA
}

XX ExpoPPGIm

Reunião Anual do Programa de Pós-graduação em Imunologia

RESUMOS

Revista Ciências Médicas e Biológicas

[Journal of Medical and Biological Sciences]

ISSN 1677 - 5090

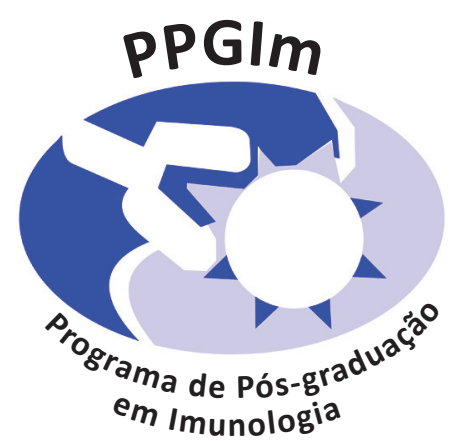

1 a 5 de setembro de 2020 
Programa de Pós-graduação em Imunologia (PPGIm) Membros do Colegiado:

Profa. Dra. Silvia Lima Costa (Cooordenadora)

Prof. Dr. Vitor Fortuna (Vice-Coordenador)

Profa. Dra. Camila Figueiredo (Docente Permanente)

Profa. Dra. Luciana Cardoso (Docente Permanente)

Profa. Dra. Maria de Fátima Costa (Docente Permanente)

Prof. Dr. Roberto Meyer (Docente Permanente)

Prof. Dr. Victor Diognes Amaral da Silva (Docente Permanente)

Balbino Lino dos Santos (Representante Estudantil)

Ana Paula Melo (Vice-representante Estudantil)

Programa de Pós-graduação em Imunologia (PPGIm) Apoio Técnico

Aline Maria Pita Luz

Jussiara Nascimento

\section{Comissão Organizadora do evento - Docentes}

Profa. Dra. Silvia Lima Costa, Coordenadora:

Prof. Dr. Vitor Antônio Fortuna, Vice-coordenador

Prof Dr Vitor Alex Torres

Prof. Dr. Vitor Alexandre Moraes Pinheiro

Profa. Dra. Bárbara de Castro Pimentel Figueiredo

Profa. Dra. Carina da Silva Pinheiro

Profa. Dra. Clarissa Schitine

Profa. Dra. Gyselle Baccan

Profa. Dra. Luciana Cardoso

Juciele Valéria Oliveira
Prof. Dr. Vitor Ricardo Wagner Dias Portela

Profa. Dra. Simone Garcia Macambira

Profa. Dra. Songeli Meneses Freire

Prof. Dr. Vitor Victor Diógenes do Amaral

\section{Comissão Organizadora do evento - Discentes}

Andressa Souza Marques

Balbino Lino dos Santos

Caio Lopes

Clara Macêdo Mimoso

Erica Misan

Isa Rita Brito de Morais

Itamara Raquel

Janaina Ribeiro Pereira Soares

Jéssika Alves Oliveira Amparo

Karina Costa da Silva

Luciano Gama da Silva Gomes

Natália da Rocha Lopes

Nívia Nonato Silva

Rodrigo Barreto Carreira

Rosimére Oliveira Torres

Taiane Gondim

Washington Santos Antunes

Organização do livro de resumos

Profa. Dra. Silvia Lima Costa

Prof. Dr. Victor Diogenes Amaral da Silva

Profa. Dra. Juciele Valeira Ribeiro

\section{Revista de Ciências Médicas e Biológicas}

Endereço: Instituto de Ciência da Saúde (ICS) - Universidade Federal da Bahia (UFBA). Av. Reitor Miguel Calmon, s/n.o, Vale do Canela. CEP: 40.110100 Salvador Bahia Brasil. Fone: (0xx71) 3283 - 8959. Fax: (0xx71) 3283 - 8894. E-mail: cimedbio@ufba.br

Site: http: //www.portalseer.ufba.br/index.php/cmbio/

Revisão dos textos em Português: Prof Roberto Paulo Correia de Araújo - Universidade Federal da Bahia - UFBA, Brasil; Marcelo Andrade Silva Santos - UFBA, Brasil; Keite Birne de Lira - Brasil

Revisão dos textos em inglês: Elisângela de Jesus Campos - Universidade Federal da Bahia - UFBA, Brasil; Gabriela Botelho Martins, Universidade Federal da Bahia - UFBA, Brasil

Normalização bibliográfica: Keite Birne Lira - Universidade Federal da Bahia, Brasil

Editoração: Virgínia Morais

Secretário: Marcelo Andrade Silva Santos

Impressão: Empresa Gráfica da Bahia (EGBA)

Tiragem e Distribuição: 500 exemplares

\section{Apoio: UFBA/CAPES}

Revista de Ciências Médicas e Biológicas = Journal of Medical and Biological Sciences / Instituto de Ciências da Saúde da Universidade Federal da Bahia. - Vol. 1, no 1 jul./dez. 2002 -. Salvador: Instituto de Ciências da Saúde, 2002 v.: il.; $30 \mathrm{~cm}$. Quadrimestral.

ISSN $1677-5090$

1. Ciências Médicas - Periódicos 2. Ciências Biológicas - Periódicos.

I. Universidade Federal da Bahia. Instituto de Ciências da Saúde.

$$
\begin{aligned}
& \text { CDD - } \quad 610.05 \\
& 574.05 \\
& \text { CDU - 61: 57(05) }
\end{aligned}
$$

(Elaborada pela Profa. Carmélia Mattos - ICI-UFBA) 


\section{Revista de Ciências Médicas e Biológicas Journal of Biological and Medical Sciences \\ ISSN 1677 - 5090}

SUMÁRIO

Volume $20 \cdot$ N. 1 - Suplemento $1-2021$

APRESENTAÇÃO - IMPORTÂNCIA DO EVENTO

\section{PESQUISADORES}

PROTEOMIC ANALYSIS OF MACROPHAGES INFECTED WHIT MYCOBACTERIUM SMEGMATIS AFTER

CHOLESTEROL CONSUMPTION

Jaqueline Batista de Lima, Juliana Silva Cassoli, Rafael Valadares Borges, Chubert Bernardo Castro de Sena, Agenor Valadares Santos

NEUROIMMUNOLOGICAL CONSEQUENCES OF CORTICOSTERONE IN A DEPRESSION MODEL

Caio Oliveira de Sá-Ferreira, Cecilia Hedin-Pereira

INFLAMMASOME ACTIVATION BY CD8 ${ }^{+}$T CELLS FROM PATIENTS WITH CUTANEOUS LEISHMANIASIS

CAUSED BY LEISHMANIA BRAZILIENSIS IN THE IMMUNOPATHOGENESIS OF THE DISEASE.

Thiago Marconi Cardoso, Jonilson B. Lima, Ícaro Bonyek-Silva, Sara Nunes, Daniel Feijó, Hugo Almeida, Juliana Silva, Aldina Barral,

Viviane Boaventura, Valéria M. Borges, Dario S. Zamboni, Lucas Pedreira de Carvalho, Edgar M. Carvalho, Natalia M. Tavares, Cláudia Brodskyn

MICRORNAS IN NEUROINFLAMMATION: IMPLICATIONS IN NEURODEGENERATIVE DISORDERS .....

Dora Brites

ADDING NEW IGE-BINDING PROTEINS OF BLOMIATROPICALIS IN THE WORLD HEALTH ORGANIZATION

OFFICIAL LIST OF ALLERGENS THROUGH PROTEOMIC ANALYSIS.

EDUARDO SILVA, JOÃO PONTE, MÁRCIA SILVA, CARINAPINHEIRO, LUIS PACHECO, FÁTIMA FERREIRA, PETER BRIZA,

NEUZA ALCÂNTARA-NEVES

DIAGNOSIS OF MALIGNANT HEMOPATHIES BY FLOW CYTOMETRY IMMUNOPHENOTYPING

Herbert Henrique Santos Melo

INVESTIGATION OF NEW DRUG CANDIDATES FOR THE TREATMENT OF INFLAMMATORY DISEASES

Gustavo Marinho Miranda, Vitória Ohana Ramos e Santos, Tiago Santos Carvalho Da Rocha, Sânzio Silva Santana, Jamile de Jesus

Vieira, Sètondji Cocou Modeste Alexandre Yahouédéhou, Marilda Souza Goncalves and Jaime Ribeiro-Filho

IMMUNOMODULATION IN CHAGAS DISEASE.

Juliana Fraga Vasconcelos

HOW THE DEVELOPMENT OF A RECOMBINANT BCG VACCINE AGAINST BORDETELLA PERTUSSIS LEAD TO

AN IMPROVED TUBERCULOSIS VACCINE.

Luciana Cezar de Cerqueira Leite

PLATFORMS FOR COVID-19 DIAGNOSISANDMONITORING.

Luiz R. Goulart, Thulio M. Cunha, Mário M. Martins, Anderson R. Santos, Murillo. G. Carneiro e Robinson Sabino-Silva.

"OMICS" AS A TOOL FOR CONTROL OF INFECTION BY AEROMONASHYDROPHILA IN AQUATIC

ORGANISMS.

Mateus Matiuzzi da Costa, Ruan Emmanuell Franco de Abreu

ANTI-INFLAMMATORY PROPERTIES DISPLAYED BY A NOVEL BIFLAVONOID REPRESENT A PROMISING

DISEASE-MODIFYING THERAPY FOR DEMYELINATING DISEASES.

Monique Marylin Alves de Almeida

MEDIADORES LIPÍDICOS NO DIABETES E AUMENTO DA SUSCEPTIBILIDADE À INFECÇÕES.

Bonyek-Silva, Icaro, Nunes, Sara, Santos, Reinan, Lima, Filipe, Lago, Alexsandro, Silva, Juliana, Carvalho, Lucas, Arruda, Sergio, Serezani, Henrique, Carvalho, Edgar, Brodskyn, Claudia , Tavares, Natalia 
Pablo I. P. Ramos

RECOMBINANT PROTEINS FOR HCV DIAGNOSTIC EVALUATION AND / OR MONITORING

Costa, Paulo Inácio da, Kenfe, Flávia Regina

CHALLENGES IN SCHISTOSOMIASIS CONTROL

SANTOS RA, DE JESUS KEM, TABAJARA Y, SILVA TM, MACEDO MN, FIALHO TRS, OLIVEIRA BSS, CASAES AC, PINHEIRO E, GRATIVAL B, FRANCISCO MVLO, CARDOSO LS, PITANGA TN, GONÇALVES MS, SIQUEIRA IC, OLIVEIRA RR

SCHISTOSOMAMANSONI SURFACE PROTEINS: THEIR ANTI-INFLAMMATORY PROPERTIES AND ROLE AS POTENTIAL MOLECULES FOR THERAPEUTICS.

Sergio C. Oliveira, Luciana S. Cardoso, Edgar M. Carvalho, Fabio S. Mambelli, Suellen B. Morais, Mariana T.Q. de Magalhães,

Barbara C. Figueiredo

PHYSALINS AS IMMUNOMODULATORY DRUGS

Vinicius Pinto Costa Rocha, Ivone Maria Ribeiro, Therezinha Tomassini Coelho Barbosa and Milena Botelho Pereira Soares

\section{DISCENTES}

A MISSENSE-TYPE VARIANT, RS41347648, DECREASES RISK OF ATOPY IN BRAZILIANS BUT NOT ASTHMA .... Talita S. Jesus, Helena Pitangueira, Gabriela P. Pinheiro, Álvaro A. S. Cruz, Ryan S. Costa, Camila A. Figueiredo

AGATHISFLAVONE INCREASES THE ASTROCYTIC POPULATION IN THE SUBVENTRICULAR ZONE AND MODULATES REACTIVE GLIOSIS IN VIVO.

Juliana Helena Castro e Silva, Francesca Pieropan, Andrea Rivera, Arthur Morgan Butt, Victor Diogenes Amaral da Silva,

Silvia Lima Costa

ANTIGENIC REACTIVITY OF RPKNG, RSPAC, RSODC AND RNANH IN A GOAT AND SHEEP SERUM

Ramon Mendes dos Santos, Silvana B. Marchioro, Caio Lopes Borges Andrade, Rogério Conceição Reis, Maria Izabel Cerqueira, Hévlyn Ribeiro de Araújo, Marcos Borges Ribeiro, Roberto Meyer, Songelí Menezes Freire

ASSESSMENT OF THE VIABILITY OF CORYNEBACTERIUM PSEUDOTUBERCULOSIS UNDER DIFFERENT

STRESS CONDITIONS

Flávia Martins da Silva, Suzana T. Cunha Lima, Roberto Meyer

ASSOCIATION OF RETN GENE POLYMORPHISM WITH ASTHMA - EFFECT MODIFICATION BY ABDOMINAL OBESITY

Raísa S. Coelho, Ana Paula C. Melo, Hátilla dos S. Silva, Helena M. P. Teixeira, Jamille S. Fernandes, Gabriela P. N. Pinheiro, Adelmir S. Machado, Álvaro A. Cruz, Camila A. Figueiredo, Ryan S. Costa

ASSOCIATION OF VARIANTS IN GENES OF THE GLUCOCORTICOID PATHWAY WITH LACK OF CONTROL IN PATIENTS WITH SEVERE ASTHMA.

Maria Borges Rabêlo de Santana, Helena Mariana Pitangueira Teixeira, Hátilla dos Santos Silva, Álvaro A. Cruz,

Camila Alexandrina Figueiredo, Ryan dos Santos Costa

ASSOCIATION OF VARIANTS IN THE PPARYGENE WITH OBESITY IN A BRAZILIAN POPULATION

Ana Paula C. Melo, Helena Mariana Pitangueira Teixeira, Raisa Santos Coelho, Neuza Maria Alcantara-Neves, Maurício Lima Barreto, Ryan dos Santos Costa, Laise C.Pinto, Camila A. Figueiredo

CHARACTERIZATION OF MI-RNAS IN THE PHENOTYPIC DYSREGULATION OF GLIOBLASTOMA AND

MICROGLIAL CELLS AND AS TARGETS OF ANTITUMORAL FLAVONOIDS

Karina Costa da Silva, Balbino Lino dos Santos, Dora Brites, Silvia Lima Costa

CHARACTERIZATION OF THE GLIAL RESPONSE ASSOCIATED TO NEUROPROTECTION INDUCED BY THE

FLAVONOID AGATHISFLAVONE IN VITRO MODELS OF BRAIN INJURY.

Verônica Moreira de Sousa, Cleonice Creusa dos Santos, Áurea Maria Alves Nunes, Juliana Helena Castro Silva, Jorge Mauricio David, Maria de Fátima Dias Costa, Arthur Morgan Butt, Victor Diógenes Amaral, Silva Lima Costa

CHARACTERIZATION OF THE IMMUNOLOGICAL MECHANISMS INDUCED IN VITRO BY THE SM29

ANTIGEN IN MACROPHAGES OF ASTHMATIC INDIVIDUALS

Luís Eduardo Ribeiro, Tarciano Nascimento, Dário Pascali, Gabriela Pimentel Pinheiro, Diego Mota Lopes, Jordana Batista, Tarcísio Almeida, Sérgio C. Oliveira, Edgar M. Carvalho, Álvaro Augusto Cruz, Luciana S. Cardoso 
CHARACTERIZATION OF THE NEUROPROTECTIVE AND ANTI-NEUROINFLAMMATORY EFFECTS OF

FLAVONOID AGATHISFLAVONE (APIGENIN AND BIS-APIGENIN): ROLE OF TRYPTOPHAN CATABOLISM

Deivison Silva Argolo, Gizelle Alves Pina, Silvia Lima Costa, Maria de Fatima Dias Costa

CIRCUMVENTING ANTIMONIAL THERAPEUTIC FAILURE IN LEISHMANIA BRAZILIENSISINFECTIONS BY

TARGETING ABC TRANSPORTERS

Marina Borges Rabelo de Santana, Edgar Marcelino de Carvalho Filho, Lucas Pedreira de Carvalho

COMBINED ADJUVANT THERAPY INVOLVING BCG AND IMIQUIMOD INCREASES THE SURVIVAL OF

C57BL/6 MICE DURING EXPERIMENTAL MELANOMA

Maiara Bonfim, Amanda Silva, Davi Salles, Rosa Pinho, Jose Mengel, Fabiola Cardillo

CYTOKINE PROFILE INDUCED BY DERMATOPHAGOIDES PTERONYSSINUS IN WHOLE BLOOD CELL

CULTURE FROMTEENAGERS IN SCAALA 2013

Flávia de Araújo Sena, Emília Maria Medeiros de Andrade Belitardo, Alana Alcântara Galvão, Laure Laine dos Santos de Jesus, Daniel dos Santos Rocha, Anaque de Oliveira Pires, Gerson de Almeida Queiroz, Álvaro Augusto Souza da Cruz Filho, Maurício Lima Barreto, Camila Alexandrina Viana de Figueiredo, Neuza Maria Alcântara Neves

DYNAMICS OF SEROCONVERSION AND IMMUNE CELL RESPONSE AS MARKERS FOR DIAGNOSIS AND

PREDICTORS OF PROGNOSIS IN SARS-COV 2 INFECTION

Isa Rita Brito de Morais, Alex José Leite Torres.

EFFECT OF SCHISTOSOMA MANSONI SM29 ANTIGEN ON MACROPHAGE INFECTIVITY BY LEISHMANIA

BRASILIENSIS

Natália Michelly Brandão Mendonça, Jordana Batista Santana, Tarciano Nascimento Pereira, Luís Eduardo Viana,

Nestor Guerrero Gutiérrez, Luciana Santos Cardoso

EFFECTS OF ASC CONDITIONED MEDIA IN TISSUE REGENERATION

Brysa Mariana Dias Silveira, Songeli Menezes Freire, Vitor Antonio Fortuna

EFFECTS OF FLAVONOID RUTIN ON GASTROINTESTINAL FUNCTION AND INTEGRITYIN AN

EXPERIMENTAL MODEL OF PARKINSON'S DISEASE.

Livia Bacelar de Jesus, Annyta Fernandes Frota, Fillipe Mendes Araújo, Rafael Leonne Cruz de Jesus, Victor Diogenes Amaral, Darizy Flavia Silva, Marcelo Biondaro Goes, Gyselle Chrystina Baccan, Silvia Lima Costa.

AGING AND CHRONIC OBSTRUCTIVE PULMONARY DISEASE: THE ROLE OF THE ENDOCRINE-IMMUNE CROSSTALK.

Fabíola Ramos Jesus, Fabine Correia Passos, Margarida Célia Neves, Antônio Carlos Lemos, Gyselle Chrystina Baccan

EVALUATION OF ANTIOXIDANT MECHANISMS OF THE FLAVONOID AGATHISFLAVONE AGAINST

NEUROINFLAMATORY DAMAGE

Janaina Ribeiro Pereira Soares, Silvia Lima Costa, Juciele Valéria Ribeiro de Oliveira

EVALUATION OF IMMUNOMODULATORY EFFECTS OF SELENIUM DIOXIDE IN MICROGLIAL RAT CELL

CULTURES INFECTED WITH NEOSPORA CANINUM .

Brenda Valerio Souza, Ana Elisa Del'Arco Vinhas Costa, Maria de Fátima Dias Costa' Silvia Lima Costa, Alexandre Moraes Pinheiro

EVALUATION OF MAPKP38, JNK AND ERK1 / 2 SIGNALING PATHWAYS IN CHRONIC PERIODONTITIS

Rebeca Pereira Bulhosa Santos, Patrícia Mares de Miranda, Michele Miranda Lopes Falcão, Soraya Castro Trindade

EVALUATION OF MICROBIOLOGICAL AND IMMUNOLOGICAL MARKERS IN THE ASSOCIATION BETWEEN

CHRONIC PERIODONTITIS AND METABOLIC SYNDROME.

Patricia Mares de Miranda, Rebeca Pereira Bulhosa Santos, Michelle Miranda Lopes Falcão, Johelle De Santana Passos Soares, Soraya Castro Trindade

EVALUATION OF THE NEUROPROTECTOR POTENTIAL OF FLAVONOIDS BIS-APIGENIN AND APIGENIN ON

AMYOTROPHIC LATERAL SCLEROSIS MODELS

Rodrigo Barreto Carreira, Victor Diógenes Amaral da Silva, Ravena Pereira Nascimento, Lucas Matheus Gonçalves de Oliveira, Ellen Cristina Vale Silva, Clarissa Schitine, Maria de Fátima Dias Costa, Cleide dos Santos Souza, Emiliano Trias, Luis Barbeito, Sílvia Lima Costa 
EVALUATION OF THE THERAPEUTIC POTENTIAL OF MESENCHYMAL CELLS THAT OVEREXPRESS IGF1 ON SKELETAL MUSCLE INJURY INDUCED BY INOCULATION OF BOTHROPS SNAKE VENOM

Kaenna Baraúna Campos, Clara Macêdo Mimoso, Luciana Lyra Casais-e-Silva, Simone Garcia Macambira

EXPRESSION AND IMUNNE RESPONSE TO RESUSCITATION PROMOTING FACTOR OF CORYNEBACTERIUM PSEUDOTUBERCULOSIS

Natália da Rocha Lopes, Luan Santana Moreira, Vitor Cordeiro Pereira, Marcos Borges Ribeiro, Roberto Meyer,

Silvana Beutinger Marchioro

GENETIC VARIANT IN MIRNA4500 ARE ASSOCIATION WITH ASTHMA AND BRONCHODILATOR RESPONSE .. Jéssica F de Araújo, HatillaS. Silva, Raisa S. Coelho, Helena M. P. Teixeira, Álvaro A. Cruz, Camila A. Figueiredo, Ryan dos S. Costa

HETEROLOGOUSPRODUCTION OF RECOMBINANT SCHISTOSOME ELASTASE

Carolina Orrico Melo Ferreira de Jesus, Beatriz de Souza Santos, Carina da Silva Pinheiro,Barbara Castro-Pimentel Figueiredo

HOMER2 GENE VARIANTS ARE ASSOCIATED WITH BDR IN ASTHMATICS ....

Helena M. P. Teixeira, Hátilla Santos, Ana Paula Castro, Talita S. Jesus, Maria B. R. de Santana, Gabriela P. Pinheiro, Álvaro A. S. Cruz, Ryan S. Costa, Camila A. Figueiredo

IDENTIFICATION OF NATURAL POLYPHENOL AND SYNTHETIC DERIVATIVES AS NEW CANDIDATES FOR THE TREATMENT OF SARS-COV2 INFECTIONS BASED ON THEIR NEUROPROTECTIVE IN PRECLINICAL MODELS OF NEUROINFLAMMATION.

William Douglas Lacerda Novais, Clarissa Schitine, Juciele Valéria Oliveira, Maria de Fátima Dias Costa, Balbino Lino dos Santos, Ravena Pereira Nascimento, Victor Diógenes Amaral da Silva, Silvia Lima Costa

IMMUNOLOGICAL CHARACTERIZATION OF PATIENTS WITH DIAGNOSIS OF COVID-19 AND RELATIONSHIP

WITH MARKERS OF VASCULAR INFLAMMATION AND NEUROINFLAMMATION.

Nívia Nonato Silva, Maria de Fátima Dias Costa, Victor Diógenes Amaral da Silva, Clarissa Schitine, Balbino Lino dos Santos, Ravena Pereira Nascimento, Vitor Antônio Fortuna, Silvia Lima Costa

IMMUNOLOGICAL RESPONSE LIVER MITOCHONDRIAL OXYGEN CONSUMPTION OF BROILERS FED SUPPLEMENTED ZINC DIETARY

Tatiane Almeida Viana Lopes, Jerônimo Ávito De Brito, Alexandre Moraes Pinheiro

IMMUNOMODULATION OF THE ETHANOLIC EXTRACT OF PHYALIS ANGULATA ON MICRÓGLIA CELL CROPS INFECTED BY NEOSPORA CANINUM.

Washington Santos Antunes, Silvia Lima Costa, Alexandre Moraes Pinheiros

INFLUENCE OF TEMPERATURE AND ANTIPYRETIC USE ON CELL VIABILITY IN PRIMARY CNS CROPS OF NEONATE RATS

Itamara Raquel dos Anjos, Silvia Lima e Costa, Clarissa Schitine, Denis de Melo Soares.

INFLUENCE OF TRYPANOSOMA CRUZI COINFECTION ON THE IMMUNE RESPONSE AND CLINICAL OUTCOME OF PATIENTS WITH CUTANEOUS LEISHMANIASIS FROM THE ENDEMIC AREA OF CORTE DE PEDRA-BAHIA, BRAZIL

Mônica Sousa Pita, Andréa Santos Magalhães, Lucas Pedreira de Carvalho,

LYMPHOCYTE PROFILE IN ACUTE MYELOID LEUKEMIA AT DIAGNOSIS AND AFTER INDUCTION THERAPY.... 200 Reis R, Santos MM, Santos AS, Santos HHM, Santos LS, Almeida BL, Peralva CMS, Meyer R, Freire SM

MODULATORY EFFECTS OF MAGNETIC STIMULATION IN ASTROCYTES: A NEUROINFLAMMATORY STUDY .. 200 Ana Elisa Del'arco, Silvia Lima Costa, Deivisson Silva Argolo, Gizelle Alves Pina, Maria de Fátima Dias Costa, Alexandre Moraes Pinheiro

NANOVACIN DEVELOPMENT USING RECOMBINANT PROTEINS OF CORYNEBACTERUIM PSEUDOTUBERCULOSIS LINKED TO POLYMERIC NANOPARTICLES.

Vitor Cordeiro Pereira, Natália da Rocha Lopes, Luan Moreira Santana, Vagner de Oliveira Machado, Marcos Borges Ribeiro, Roberto Meyer, Silvana Beutinger Marchioro 
NICOTINE INHIBITS AMINOCHROME-INDUCED IN VITRO CYTOTOXICITY: PERSPECTIVES FOR

APPLICATION IN PARKINSON'S DISEASE

Érica Novaes Soares, Ana Carla Costa, Cleonice Creusa dos Santos, Maria de Fátima Dias Costa, Yussef Tsabl, Silvia Lima Costa,

Victor Diogenes Amaral da Silva

PERIPHERAL BLOOD CD4 ${ }^{+}$T CELLS PROFILE IN SICKLE CELL DISEASE PATIENTS WITH OSTEONECROSIS

Paula Braga Daltro, Vitor Antonio Fortuna, Roberto José Meyer Nascimento

POLYMORPHIMS IN IFI16 GENEARE ASSOCIATED WITH PERIODONTAL DISEASE IN A POPULATION IN

SALVADOR/BA-BRAZIL

Marcia Otto Barrientos, Tatiane de Oliveira Teixeira Muniz Carletto, Helena M. P. Teixeira, Soraya Castro Trindade, Álvaro A. S. Cruz,

Camila A. Figueiredo, Ryandos Santos Costa

PRETREATMENT NEUTROPHIL-TO-LYMPHOCYTE RATIO AS PROGNOSTIC PARAMETER FOR SURGICAL RESECTION IN ADVANCED ORAL SQUAMOUS CELL CARCINOMA PATIENTS.

Renata Freitas Araujo-Calumby, André Leonardo de Castro Costa, Anna Beatriz Pereira Simões Alves, Camila da Silva Souza, Danie Nascimento, Deyse Souza Carvalho da Silva, Geovane de Jesus Santos, Gessualdo Seixas Oliveira Junior, Herval Bruno Moreira dos Santos Filho, Matheus Antônio da Hora Borges, Miguel de Jesus Oliveira Santos, Lucianna Stutz Souza Carneiro de Campos, Vitor Silva de Oliveira, Marcus Antônio de Mello Borba, Lucas Gomes Silva, Iguaracyra Araújo, Rodrigo Tripodi Calumby, Silvia Lima Costa, Deise Souza Vilas-Bôas

POLYMORPHISMSRELATED TO TYPE 2 INNATE LYMPHOID CELLS ARE ASSOCIATED WITH ASTHMA AND ATOPY IN A BRAZILIAN POPULATION

Louise C. de Lima, Álvaro A. Cruz, Hatilla dos S. Silva, Raísa S. Coelho, Ryan dos S. Costa, Camila A. V. Figueiredo,

Vadirene L. Carneiro

PROPOSITION OF NATURAL COMPOUNDS AND CHIMERIC PROTEINS FOR NOVEL PROPHYLACTIC METHODS AGAINST STREPTOCOCCUSEQUI

Bernardo Mirabal Santos, Sarah Pereira Andrade de Souza, Igor Batista dos Santos Oliveira, Letícia Vivas Carvalho, Nubia Seyffert, Roberto Meyer, Thiago Luiz de Paula Castro

PROSPECTING FOR N-HETEROCYCLIC COMPOUNDS TO CHARACTERIZATION OF ANTIGLIOMA ACTION MECHANISMS IN GLIOBLASTOMA CELLS AND IN INTERACTION WITH MICROGLIA.....

Jéssika Alves Oliveira Amparo, Raimundo Francisco dos Santos Filho, Victor Diógenes Amaral da Silva, Silvio do Desterro Cunha, Ravena Pereira do Nascimento, Silvia Lima Costa

SUPPORT: CNPQ (PROC. 443723/2014-, PARTIALLY), INCT - NACIONAL INSTITUTE FOR TRANSLATIONAL NEUROSCIENCE AND INCT FOR EXCITOTOXICITY AND NEUROPROTECTION (MCTI/CNPQ), FAPESB(MPHIL FELLOWSHIP).

Jordana Batista Santana, Tarcísio Vila Verde S. de Almeida, Diego Mota Lopes, Luís Eduardo Ribeiro, Néstor A. Guerrero Gutierreza, Edgar M. Carvalho, Luciana Santos Cardoso

QUANTIFICATION AND COMPREHENSIVE ANALYSIS OF MESENCHYMAL STROMAL CELLS IN BONE MARROW SAMPLES FROM SICKLE CELL DISEASE PATIENTS WITH OSTEONECROSIS

Tiago Oliveira Ribeiro, Songeli Menezes Freire, Vitor Antonio Fortuna

REVERSE VACCINOLOGY IN MURINE MODEL AND CANINE FOR THE CONTROL OF TOXOCARACANIS INFECTION

Dumar Alexander Jaramillo Hernández, Luis Fabián Salazar Garcés, Carina Silva Pinheiro, Neuza Maria Alcantara-Neves

RUTIN INHIBITS GLIAL ACTIVATION AND PROTECTS DOPAMINERGIC NEURONS AGAINST 6-OHDA AND

AMINOCHROME CYTOTOXICITY IN ANIMAL MODEL. ARAÚJO, F.M., FROTA, A.F., JESUS, L.B., MACEDO, T.C., SANCHEZ-RODRIGO C., MENDES, K.M.F., CUENCA L., SEGURA-AGUILAR, J., COSTA, S.L., HERRERO, MT, SILVA, V.D.A.

SCREENING OF MACHINE LEARNING ALGORITHMS FOR THE PREDICTION OF ASTHMA USING GENETIC MARKERS

Luciano Gama da Silva Gomes, Camila Alexandrina Figueiredo, Álvaro Augusto Souza da Cruz Filho, Ryan dos Santos Costa 
Caio Lopes Borges Andrade, Ramon Mendes dos Santos, Rogério Reis Conceição, Hévlyn Ribeiro de Araújo, Maria Isabel Cerqueira,

Marcos Borges Ribeiro, Roberto José Meyer Nascimento, Songelí Menezes Freire

SKELETAL MUSCLE INJURY INDUCED BY BOTHROPSLEUCURUS VENON AND TISSUE REPAIR:

INFLAMMATORY PROFILE AND MECHANISMS INVOLVED

Clara Macêdo Mimoso, Kaenna Baraúna Campos, Simone Garcia Macambira, Luciana Lyra Casais-e-Silva

STUDY OF GLIAL RESPONSE IN A NEW IN VITRO MODEL OF CEREBELLAR CELL CULTURE

Santana, L. F, Santos, C. C, Ferreira, R. S, Ameida, A. M. A. N, De Castro, M. V. L, Franchi, M. S, Andrade, G. B, Da Silva, T. M, Costa, S.

L. and Silva, V. D. A

STUDY OF THE FLAVONOID RUTIN EFFECT ON ANTI-INFLAMMATORY AND ANTIVIRAL RESPONSES IN

DIFFERENT BRAIN REGIONS DURING DEVELOPMENT.

Rosimére Oliveira Torres, Silvia Lima Costa and Clarissa de Sampaio Schitine

STUDY OF THE MOLECULAR MECHANISMS ASSOCIATEDWITH ANTIGLIOMA AND IMMUNOMODULATORY EFFECTS OF FLAVONOIDS RELATEDTO INTERACTION WITH AHR

Monique Reis de Santana, Ravena Pereira do Nascimento, David Gilot, Silvia Lima Costa

STUDY OF VARIANTS IN THE IL17 GENE IN DIFFERENT PEDIATRIC ASTHMA ENDOPHENOTYPES,

INCLUDING GLUCOCORTICOID RESISTANT ASTHMA

Saulo Ferreira de Assis, Laura Maria de Lima, Belizario Facury Lasmar, Ryan dos Santos Costa.

THE FLAVONOID AGATHISFLAVONE MODULATES MICROGLIAL ACTIVATION AND PRESENTS

NEUROPROTECTIVE EFFECTS IN VITRO MODEL OF NEUROINFLAMMATION

Balbino Lino dos Santos, Cleonice Creusa dos Santos, Victor Diogenes Amaral da Silva, Silvia Lima Costa

THE GLUCOCORTICOID RECEPTOR CONTRIBUTES TO REDUCTION OF LPS-INDUCED GLIAL REACTIVITY IN VITRO BY AGATHISFLAVONE

Áurea Maria Alves Nunes Almeida, Cleonice Creusa dos Santos, Gloriene Carvalho de Jesus, Larissa Pedreira da Silva, Verônica Moreira de Souza, Ana Elisa Del'Arco Vinhas Costa, Balbino Lino Dos Santos, Victor Diógenes Amaral da Silva,

Suzana Braga de Souza, Silvia Lima Costa

THE USE OF TUMOR ANTIGENS IN THE IMMUNIZATION OF ANIMALS CHRONICALLY INFECTED WITH TRYPANOSOMA CRUZI PREVIOUSLY TREATED WITH ADJUVANTS.

Amanda Silva, Davi Salles, Maiara Bonfim, Jose Mengel, Fabiola Cardillo

ZIKA VIRUS SINGULAR PEPTIDE PRODUCTION FOR THE DEVELOPMENT OF SEROLOGICAL

IMMUNOASSAYS AND EVALUATION OF IMMUNE RESPONSE.

Rafael Ribeiro Mota Souza, Isabela Brandão Peixoto, Rejane Hughes Carvalho, Gubio Soares Campos, Roberto José Meyer Nascimento, Silvia Ines Sardi 


\section{IMPORTÂNCIA DO EVENTO}

O Programa de Pós-graduação em Imunologia (PPGIm) há mais de 30 anos, vem formando recursos humanos de excelência, capacitados para as atividades de ensino e pesquisa em Imunologia e áreas correlatas, muitos já absorvidos por instituições da Bahia e de outros estados. O PPGIm tem realizado reuniões científicas visando difusão do conhecimento científico e integração acadêmica com a graduação e a pós-graduação da própria UFBA e outras IES. A ExpoPPGIm, Reunião Anual do Programa, já se tornou um evento tradicional, que acontece a cada ano, com a primeira edição no ano 2000, constituindo um fórum de integração de profissionais, pesquisadores e jovens cientistas, alunos de graduação e pós-graduação da UFBA e outras IES do Estado da Bahia, do Brasil e de outros Países com interesse no amplo domínio da Imunologia. O objetivo da ExpoPPGIm é divulgar conhecimento científico em Imunologia e áreas correlatas, gerado localmente, na Bahia, no Brasil, e outros países, tendo como público-alvo estudantes de graduação e pós-graduação, pesquisadores da UFBA e outras IES e profissionais da área. Esta XX Edição da ExpoPPGIm foi realizada inteiramente de forma virtual e contou com a participação como palestrantes além de pesquisadores da própria UFBA, pesquisadores vinculados a outras instituições de ensino e pesquisa da Bahia, do Brasil e do exterior, que apresentaram palestras em 6 sessões temáticas, relacionadas às linhas de pesquisa do Programa. Ainda, durante os 5 dias do evento, discentes do Programa apresentaram e discutiram sobre seus projetos de pesquisa em desenvolvimento através de vídeo-pôsteres, distribuídos em 8 sessões, e assim também contribuindo para a integração acadêmica e a difusão do conhecimento científico em Imunologia e seus correlatos. 



\section{ExpoPPGIm}

\section{Reunião Anual do Programa de Pós-graduação em Imunologia 1 a 5 de setembro de 2020 http://www.ppgim.ics.ufba.br/ https: //zoom.us/ \\ PROGRAMAÇÃO}

\begin{tabular}{|c|c|c|}
\hline \multirow[t]{4}{*}{$01 / 09$} & \multicolumn{2}{|c|}{$\begin{array}{l}\text { ABERTURA DO EVENTO } \\
\text { 09: } 00-09: 15 \mathrm{~h}\end{array}$} \\
\hline & \multicolumn{2}{|c|}{$\begin{array}{l}\text { APRESENTAÇÃO DO PROGRAMA DE PÓS-GRADUAÇÃO EM IMUNOLOGIA DA UFBA } \\
\text { Silvia Lima Costa - Coordenadora do PPGIm }\end{array}$} \\
\hline & \multicolumn{2}{|c|}{$\begin{array}{c}\text { CONFERÊNCIA PLENÁRIA } \\
\text { 09: 15 - 11: } 00 \mathrm{~h} \\
\text { derador: Vitor Antônio Fortuna - Vice-coordenador do PPGIm }\end{array}$} \\
\hline & \multicolumn{2}{|c|}{$\begin{array}{l}\text { TESTES SOROLÓGICOS E RESPOSTA IMUNE A SARS-COV2 } \\
\text { Roberto José Meyer Nascimento } \\
\text { Laboratório de Imunologia e Biologia Molecular (Lablmuno) - UFBA }\end{array}$} \\
\hline \multirow[t]{4}{*}{ 01/09 } & \multicolumn{2}{|c|}{$\begin{array}{c}\text { SESSÃO TEMÁTICA - IMUNOLOGIA APLICADA } \\
\text { 13: } 00-15: 00 \mathrm{~h} \\
\text { Moderadores: Songelí M. Freire, Alex Torres e Rosimére Torres }\end{array}$} \\
\hline & $\begin{array}{l}\text { Challenges in schistosomiasis control - point-of-care } \\
\text { circulating cathodic antigen (POC-CCA). }\end{array}$ & $\begin{array}{l}\text { Ricardo Riccio Oliveira } \\
\text { Fundação Oswaldo Cruz-CPqGM }\end{array}$ \\
\hline & $\begin{array}{l}\text { Recombinant proteins for HCV diagnostic evaluation } \\
\text { and / or monitoring }\end{array}$ & $\begin{array}{l}\text { Paulo Inácio da Costa } \\
\text { Faculdade de Medicina de Ribeirão Preto } \\
\text { Universidade do estado de São Paulo } \\
\end{array}$ \\
\hline & $\begin{array}{l}\text { Diagnosis of malignant hemopathies by flow cytometry } \\
\text { immunophenotyping. }\end{array}$ & $\begin{array}{l}\text { Herbert Henrique Santos Melo } \\
\text { Serviço de hematologista do HUPES } \\
\text { Lablmuno - UFBA }\end{array}$ \\
\hline
\end{tabular}




\section{$01 / 09$ \\ SESSÃO - APRESENTAÇÃO DISCENTES 1 \\ 16: 00 - 18: $00 \mathrm{~h}$ \\ Moderadores: Victor Diógenes Silva e Jéssika Amparo}

Proposition of natural compounds and chimeric Bernardo Mirabal Santos, Sarah Pereira Andrade de proteins for novel prophylactic methods against Souza, Igor Batista dos Santos Oliveira, Letícia Vivas Streptococcus equi. Carvalho, Nubia Seyffert, Thiago Luiz de Paula Castro.

Evaluation of microbiological and immunological markers in the association between chronic periodontitis and metabolic syndrome.

Patricia Mares de Miranda, Rebeca Pereira Bulhosa Santos, Michelle Miranda Lopes Falcão, Johelle De Santana Passos Soares, Soraya Castro Trindade.

Ramon Mendes dos Santos, Silvana Beutinger MarAntigenic reactivity of RPKNG, RSPAC, RSODC and RNANH in a goat and sheep serum.

chioro, Caio Lopes Borges Andrade, Rogerio Reis Conceição, Maria Isabel Cerqueira, Hévlyn Ribeiro de Araújo, Marcos Borges Ribeiro, Roberto Jose Meyer Nascimento, Songelí Meneses Freire.

Nanovaccine development using recombinant Vítor Cordeiro Pereira, Vagner de Oliveira Machado, proteins of Corynebacterium pseudotuberculosis linked to polymeric nanoparticle Marcos Borges Ribeiro, Roberto Jose Meyer Nascimento, Luan Santana Moreira, Silvana Beutinger Marchioro

Peripheral blood CD4+ $t$ cells profile in sickle cell disease patients with osteonecrosis

Paula Braga Daltro, Vitor Antônio fortuna, Roberto José Meyer Nascimento

Effects of ASC conditioned media in tissue regeneration.

Brysa Mariana Dias Silveira, Songelí Meneses Freire, Vitor Antônio fortuna

Quantification and comprehensive analysis of mesenchymal stromal cells in bone marrow samples from sickle cell disease patients with osteonecrosis.

Tiago Oliveira Ribeiro, Songelí Meneses Freire, Vitor Antônio fortuna 
Moderadores: Clarissa Schitine e Janaína Ribeiro Soares

Combined adjuvant therapy involving BCG and Maiara Nelma Bonfim Costa, Amanda Catariny de Oliimiquimod increases the survival of C57BL/6 mice veira Silva, Davi Salles Xavier, Rosa Pinho, José Mengel, during experimental melanoma.

Dynamics of seroconversion and immune cell response as markers for diagnosis and predictors of prognosis in SARS-CoV 2 infection.

Immunological characterization of patients with diagnosis of COVID-19 and relationship with markers of vascular inflammation and neuroinflammation. Fabiola Cardillo.

Isa Rita Brito de Morais, Alex José Leite Torres.

Nívia Nonato Silva, Maria de Fátima Dias Costa, Victor Diógenes Amaral da Silva, Clarissa Schitine, Balbino Lino dos Santos, Ravena Pereira Nascimento, Vitor Antônio Fortuna, Silvia Lima Costa.

Identification of natural polyphenol and synthetic William Douglas Lacerda Novais, Clarissa Schitine, derivatives as new candidates for the treatment of Juciele Valéria Oliveira, Maria de Fátima Dias Costa, sars-cov2 infections based on their neuroprotective Balbino Lino dos Santos, Ravena Pereira Nascimento, in preclinical models of neuroinflammation. Victor Diógenes Amaral da Silva, Silvia Lima Costa. Influence of temperature and antipyretic use on cell Itamara Raquel dos Anjos, Silvia Lima Costa, Denis de viability in primary CNS crops of neonate rats. Melo Soares, Clarissa Schitine.

\begin{tabular}{|l|l|}
$\begin{array}{l}\text { Genetic analysis technologies helping to study asthma } \\
\text { immunology. }\end{array}$ & $\begin{array}{l}\text { Rafael Valente Veiga } \\
\text { Laboratório de Alergia e Acarologia - UFBA }\end{array}$ \\
\hline $\begin{array}{l}\text { New immunological and molecular biomarkers in } \\
\text { severe asthma. }\end{array}$ & $\begin{array}{l}\text { Emília Maria Medeiros de Andrade Belitardo } \\
\text { Laboratório de Alergia e Acarologia - UFBA }\end{array}$ \\
\hline $\begin{array}{l}\text { Asthma epigenetics - How environmental factors can } \\
\text { affect the regulation of gene expression in asthma. }\end{array}$ & $\begin{array}{l}\text { Cinthia Vila Nova Santana } \\
\text { Escola Bahia de Medicina e Saúde Publica }\end{array}$ \\
\hline $\begin{array}{l}\text { Monocytes with pro-fibrotic phenotype in the } \\
\text { pathogenesis of severe asthma. }\end{array}$ & $\begin{array}{l}\text { Jamille Souza Fernandes } \\
\text { Universidade Federal do Oeste da Bahia }\end{array}$ \\
\hline
\end{tabular}




\begin{tabular}{|c|c|c|}
\hline \multirow[t]{7}{*}{ 02/09 } & \multicolumn{2}{|c|}{$\begin{array}{c}\text { SESSÃO APRESENTAÇÃO DISCENTES } 3 \\
\text { 16: 00-18: } 00 \mathrm{~h} \\
\text { Moderadores: Maria de Fátima Dias Costa e Karina Costa da Silva }\end{array}$} \\
\hline & $\begin{array}{l}\text { Polymorphims in IFI16 gene are associated with } \\
\text { periodontal disease in a population in Salvador/ } \\
\text { BA-Brazil }\end{array}$ & $\begin{array}{l}\text { Marcia Otto Barrientos, Tatiane de Oliveira Teixeira } \\
\text { Muniz Carletto, Helena Teixeira, Soraya Castro Trin- } \\
\text { dade, Álvaro A. S. Cruz, Camila Alexandrina Viana } \\
\text { Figueiredo, Ryan dos Santos Costa }\end{array}$ \\
\hline & $\begin{array}{l}\text { A missense-type variant, RS41347648, decreases risk } \\
\text { of atopy in Brazilians but not asthma }\end{array}$ & $\begin{array}{l}\text { Talita dos Santos de Jesus, Helena Teixeira, Gabriela } \\
\text { P. Pinheiro, Álvaro A. S. Cruz, Ryan dos Santos Costa, } \\
\text { Camila Alexandrina Viana Figueiredo }\end{array}$ \\
\hline & $\begin{array}{l}\text { Characterization of the immunological mechanisms } \\
\text { induced in vitro by the SM } 29 \text { antigen in macrophages } \\
\text { of asthmatic individuals }\end{array}$ & $\begin{array}{l}\text { Luís Eduardo Viana Silva Ribeiro, Tarciano Nascimento } \\
\text { Pereira, Dário Jesus de Pascali, Gabriela P. Pinheiro, } \\
\text { Jordana Batista Santana, Diego Mota Lopes, Sergio } \\
\text { Costa Oliveira, Edgar Marcelino De Carvalho Filho, } \\
\text { Álvaro A. S. Cruz, Luciana Santos Cardoso }\end{array}$ \\
\hline & $\begin{array}{l}\text { Association of RETN gene polymorphism with asthma } \\
\text { - effect modification by abdominal obesity. }\end{array}$ & $\begin{array}{l}\text { Raísa Santos Coelho, Ana Paula Castro Melo, Hatilla } \\
\text { Santos, Helena Teixeira, Jamile S Fernandes, Gabriela P. } \\
\text { Pinheiro, Adelmir S Machado, Álvaro A. S. Cruz, Camila } \\
\text { Alexandrina Viana Figueiredo, Ryan dos Santos Costa. }\end{array}$ \\
\hline & $\begin{array}{l}\text { Association of variants in the PPARY gene with obesity } \\
\text { in a Brazilian population. }\end{array}$ & $\begin{array}{l}\text { Ana Paula C. Melo, Helena Mariana Pitangueira Teixei- } \\
\text { ra; Raisa Santos Coelho, Neuza Maria Alcantara-Neves, } \\
\text { Maurício Lima Barreto, Ryan Dos Santos Costa, Laise } \\
\text { C.Pinto, Camila A. Figueiredo. }\end{array}$ \\
\hline & $\begin{array}{l}\text { Cytokine profile induced by Dermatophagoides } \\
\text { pteronyssinus in whole blood cell culture from } \\
\text { teenagers in SCAALA } 2013 \text {. }\end{array}$ & $\begin{array}{l}\text { Flávia de Araújo Sena, Emília Maria Medeiros de An- } \\
\text { drade Belitardo, Alana Alcântara Galvão, Laure Laiane } \\
\text { dos Santos de Jesus, Daniel dos Santos Rocha, Anaque } \\
\text { de Oliveira Pires, Gerson de Almeida Queiroz, Álvaro } \\
\text { A. S. Cruz, Maurício Lima Barreto, Camila Alexandrina } \\
\text { Viana Figueiredo, Neuza Maria Alcântara Neves. }\end{array}$ \\
\hline \multirow[t]{5}{*}{ 02/09 } & \multicolumn{2}{|c|}{$\begin{array}{l}\text { SESSÃO - APRESENTAÇÃO ORAL DISCENTES } 4 \\
\text { 19: 00-21: } 00 \mathrm{~h} \\
\text { dores: Juciele Valéria Oliveira e Andressa Souza Marques }\end{array}$} \\
\hline & $\begin{array}{l}\text { HOMER2 gene variants are associated with BDR in } \\
\text { asthmatics. }\end{array}$ & $\begin{array}{l}\text { Helena Teixeira, Hatilla Santos, Ana Paula Castro Melo, } \\
\text { Talita dos Santos de Jesus, Maria Borges Rabêlo de } \\
\text { Santana, Ryan dos Santos Costa, Camila Alexandrina } \\
\text { Viana Figueiredo. }\end{array}$ \\
\hline & $\begin{array}{l}\text { Association of variants in genes of the glucocorticoid } \\
\text { pathway with lack of control in patients with severe } \\
\text { asthma. }\end{array}$ & $\begin{array}{l}\text { Maria Borges Rabêlo de Santana, Helena Teixeira, } \\
\text { Hatilla Santos, Álvaro A. S. Cruz, Camila Alexandrina } \\
\text { Viana Figueiredo, Ryan dos Santos Costa. }\end{array}$ \\
\hline & $\begin{array}{l}\text { Screening of machine learning algorithms for the } \\
\text { prediction of asthma using genetic markers. }\end{array}$ & $\begin{array}{l}\text { Luciano Gama da Silva Gomes, Camila Alexandrina } \\
\text { Viana de Figueiredo, Álvaro Augusto Souza da Cruz } \\
\text { Filho, Ryan dos Santos Costa. }\end{array}$ \\
\hline & $\begin{array}{l}\text { Genetic variant in mirna4500 are association with } \\
\text { asthma and bronchodilator response }\end{array}$ & $\begin{array}{l}\text { Jéssica F de Araújo, HatillaS. Silva, Raisa S. Coelho, } \\
\text { Helena M. P. Teixeira, Álvaro A. Cruz, Camila A. Figuei- } \\
\text { redo, Ryan dos S. Costa }\end{array}$ \\
\hline
\end{tabular}




\section{3/09}

$03 / 09$

\section{SESSÃO TEMÁTICA - SARS-COV2}

09: 00-11: $00 \mathrm{~h}$

Moderadores: Ricardo Wagner Portela, Vitor Antônio Fortuna e Rodrigo Carreira

\begin{tabular}{|l|l|}
\hline A Brazilian experience in the diagnosis of Covid19. & $\begin{array}{l}\text { Abelardo Silva Junior } \\
\text { Universidade Federal de Viçosa }\end{array}$ \\
\hline $\begin{array}{l}\text { Development of new methodologies for the diagnosis } \\
\text { of SARS-COV2 infection. }\end{array}$ & $\begin{array}{l}\text { Jussi Hepojoki } \\
\text { Universidade de Helsinki }\end{array}$ \\
\hline SARS-VOC-2 infection in animals and its diagnosis. & $\begin{array}{l}\text { Luiz Eduardo Ristow } \\
\text { Laboratório TECSA }\end{array}$ \\
\hline
\end{tabular}

\section{SESSÃO TEMÁTICA - NEUROIMUNOENDOCRINOLOGIA E IMUNOFARMACOLOGIA}

13: 00-15: $00 \mathrm{~h}$

Moderadores: Silvia Lima Costa, Clarissa Schitine e Karina Costa

MicroRNAs in neuroinflammation: implications for Dora Brites

neurodegenerative diseases.

Universidade de Lisboa

Aspects of neuroinflammation associated with Maria Trinidad Herrero Ezquerro

Parkinson's disease.

Universidade de Murcia

Neuroimmunological consequences of corticosterone Cecilia Hedin Pereira

depression.

Universidade Federal do Rio de Janeiro

The anti-inflammatory properties shown by a new

biflavonoid represent a promising modifying therapy

for demyelinating diseases.

\section{6: $00-18: 00 \mathrm{~h}$}

Moderadores: Simone Garcia Macambira e Cleonice Creusa dos Santos

Rutin inhibits glial activation and protects dopaminergic Fillipe Mendes De Araujo, Annyta Fernandes Frota, Lineurons against 6 - OHDA and aminochrome via Bacelar De Jesus, Silvia Lima Costa, Maria Trinidadcytotoxicity in animal model. -Herrero, Victor Diógenes Amaral Da Silva.

Effects of flavonoid rutin on gastrointestinal function and integrity in an experimental model of Parkinson's Disease.

Livia Bacelar de Jesus, Annyta Fernandes Frota, Fillipe Mendes De Araujo, Rafael Leonne Cruz de Jesus, Victor Diógenes Amaral da Silva, Darizy Flavia Silva, Marcelo Biondaro Gois, Gyselle Chrystina Baccan, Silvia Lima Costa.

The flavonoid agathisflavone modulates microglial Balbino Lino dos Santos, Cleonice Cleuza dos Santos, activation and presents neuroprotective effects in vitro model of neuroinflammation.

Agathisflavone increases the astrocytic population in the subventricular zone and modulates reactive gliosis in vivo.

Victor Diógenes Amaral da Silva, Silvia Lima Costa.

Juliana Helena Castro e Silva, Francesca Pieropan, Andrea Rivera, Arthur Morgan Butt, Victor Diogenes Amaral da Silva, Silvia Lima Costa.

The glucocorticoid receptor contributes to reduction of Ips-induced glial reactivity in vitro by agathisflavone.

Áurea Maria Almeida, Cleonice Cleuza dos Santos, Gloriene Carvalho De Jesus, Victor Diógenes Amaral da Silva, Suzana Braga de Souza, Silvia Lima Costa.

Evaluation of the neuroprotector potential of flavonoids bis-apigenin and apigenin on amyotrophic lateral sclerosis models.

Rodrigo Barreto Carreira, Victor Diógenes Amaral da Silva, Ravena Pereira Nascimento, Lucas Matheus Gonçalves de Oliveira, Luis Barbeito, Silvia Lima Costa. 


03/09 $\begin{gathered}\text { SESSÃO - APRESENTAÇ } \\ \text { 19: 00-2 } \\ \text { Moderadores: Luciana Cand }\end{gathered}$
$\begin{aligned} & \text { Nicotine inhibits aminochrome-induced in vitro } \\ & \text { cytotoxicity: perspectives for application in Parkinson's } \\ & \text { disease. }\end{aligned}$
$\begin{aligned} & \text { Evaluation of antioxidant mechanisms of the flavonoid } \\ & \text { agathisflavone against neuroinflammatory damage }\end{aligned}$
$\begin{aligned} & \text { Prospecting for n-heterocyclic compounds to } \\ & \text { characterization of antiglioma action mechanisms in } \\ & \text { glioblastoma cells and in interaction with microglia. }\end{aligned}$

Study of the molecular mechanisms associated with antiglioma and immunomodulatory effects of flavonoids.

Characterization of mi-RNAs in the phenotypic dysregulation of glioblastoma and microglial cells and as targets of antitumoral flavonoids.

\section{SESSÃO - APRESENTAÇÃO ORAL DISCENTE 7}

\section{9: 00-11: $00 \mathrm{~h}$}

Moderadores: Alexandre Moraes Pinheiro e Balbino Lino dos Santos

Immunomodulation of the ethanolic extract of Phyalis angulata on micróglia cell crops infected by Neospora caninum.

Evaluation of immunomodulatory effects of selenium dioxide in microglial rat cell cultures infected with Neospora caninum.

Reverse vaccinology in murine model and canine for the control of Toxocara canis infection.

Washington Santos Antunes, Silvia Lima Costa, Alexandre Moraes Pinheiro.

Brenda Valerio Souza, Ana Elisa Del'Arco Vinhas Costa, Maria de Fátima Dias Costa, Silvia Lima Costa, Alexandre Moraes Pinheiro.

Dumar Alexander Jaramillo Hernández, Carina da Silva Pinheiro, Luis Fabián Salazar Garcés, Neuza Maria Alcântara Neves.

Influence of Trypanosoma cruzi coinfection on the immune response and clinical outcome of patients with cutaneous leishmaniasis from the endemic area of Corte de Pedra-Bahia, Brazil.

Heterologous production of recombinant Schistosome elastase.

Mônica Sousa Pita, Andréa Santos Magalhães, Lucas Pedreira de Carvalho.

Carolina Orrico Melo Ferreira de Jesus, Barbara de Castro Pimentel Figueiredo, Carina da Silva Pinheiro, Beatriz de Souza Santos.

Protective and profibrotic cytokines mediated by Jordana Batista Santana, Tarcísio Vila Verde S. de CD4+ T lymphocytes in periportal fibrosis secondary Almeida, Diego Mota Lopes, Luís Eduardo Viana Silva to schistosomiasis.

Ribeiro, Néstor A. Guerrero Gutierrez, Edgar Marcelino de Carvalho Filho, Luciana Santos Cardoso.

The use of tumor antigens in the immunization of Amanda Silva, Davi Salles, Maiara Bonfim, Jose Menanimals chronically infected with Trypanosoma cruzi previously treated with adjuvants 


\section{3: $00-15: 00 \mathrm{~h}$}

Moderadores: Barbara de Castro Figueiredo, Carina da Silva Pinheiro e Rosimére Torres

\begin{tabular}{|c|c|}
\hline $\begin{array}{l}\text { Schistosoma mansoni surface proteins: their anti- } \\
\text { inflammatory properties and role as potential } \\
\text { molecules for therapeutics. }\end{array}$ & $\begin{array}{l}\text { Sergio Costa Oliveira } \\
\text { Universidade Federal de Minas Gerais }\end{array}$ \\
\hline $\begin{array}{l}\text { How the development of a Recombinant BCG vaccine } \\
\text { against Bordetella pertussis lead to an improved } \\
\text { Tuberculosis vaccine. }\end{array}$ & $\begin{array}{l}\text { Luciana Cezar de Cerqueira Leite } \\
\text { Instituto Butantan }\end{array}$ \\
\hline Platforms for COVID-19 diagnosis and monitoring. & \begin{tabular}{|l|} 
Luiz Ricardo Goulart Filho \\
Universidade Federal de Uberlândia
\end{tabular} \\
\hline $\begin{array}{l}\text { Inflammasome activation by CD8+T cells from Patients } \\
\text { with Cutaneous Leishmaniasis caused by Leishmania } \\
\text { braziliensis in the immunopathogenesis of the disease. }\end{array}$ & \begin{tabular}{|l|} 
Cláudia Ida Brodskyn \\
Fundação Oswaldo Cruz-CPqGM
\end{tabular} \\
\hline
\end{tabular}

Study of glial response in a new in vitro model of Lucia Fonseca Santana, Cleonice Creuza dos Santos, cerebellar cell culture.

Rafael Short Ferreira, Maria Victoria Lima de Castro, Silvia Lima Costa, Victor Diogenes Amaral da Silva.

Evaluation of the therapeutic potential of mesenchymal Kaenna Baraúna Campos, Luciana Lyra Casais E. Silva, cells that overexpress IGF1 on skeletal muscle injury Clara Macêdo Mimoso, Simone Garcia Macambira. induced by inoculation of Bothrops snake venom.

Skeletal muscle injury induced by Bothrops leucurus venon and tissue repair: inflammatory profile and mechanisms involved.

Clara Macêdo Mimoso, Kaenna Baraúna Campos, Simone Garcia Macambira, Luciana Lyra Casais E. Silva.

mechanisms involved.

Pretreatment neutrophil-to-lymphocyte ratio as prognostic parameter for surgical resection in advanced oral squamous cell carcinoma patients.

Renata Freitas Araujo-Calumby, André Leonardo de Castro Costa, Deyse Souza Carvalho Da Silva, Daniel Nascimento, Anna Beatriz Pereira Simões Alves, Miguel de Jesus Oliveira Santos, Lucianna Stutz Souza Carneiro de Campos, Gessualdo Seixas Oliveira Junior, Matheus Antonio da Hora Borges, Camila da Silva Souza, Marcus Antonio de Mello Borba, Lucas Gomes Da Silva, Iguaracyra Barreto de Oliveira Araujo, Rodrigo Tripodi Calumby, Silvia Lima Costa, Deise Souza Vilas Bôas.

Evaluation of mapkp38, JNK and ERK1 / 2 signaling Rebeca Pereira Bulhosa Santos, Patricia Mares de pathways in chronic periodontitis Miranda, Michelle Miranda Lopes Falcão, Soraya Castro Trindade 


\begin{tabular}{|c|c|c|}
\hline \multirow[t]{5}{*}{ 05/09 } & \multicolumn{2}{|c|}{$\begin{array}{l}\text { SESSÃO TEMÁTICA - IMUNOGENÉTICA, GENÔMICA E PROTEÔMICA } \\
\text { 9: 00-11: } 00 \text { h } \\
\text { Moderadores: Thiago Luiz Castro, Silvana Marchioro e Clara Macêdo }\end{array}$} \\
\hline & $\begin{array}{l}\text { Omics as a tool for control of infection by Aeromonas } \\
\text { hydrophila in aquatic organisms. }\end{array}$ & $\begin{array}{l}\text { Mateus Matiuzzi da Costa } \\
\text { Universidade do Vale do São Francisco }\end{array}$ \\
\hline & $\begin{array}{l}\text { Omics applied to the study of pathogenic } \\
\text { microorganisms. }\end{array}$ & $\begin{array}{l}\text { Pablo Ivan Pereira Ramos } \\
\text { Fundação Oswaldo Cruz-CPqGM }\end{array}$ \\
\hline & $\begin{array}{l}\text { Proteomic analysis of macrophages infected with } \\
\text { Mycobacterium smegmatis after consumption of } \\
\text { cholesterol. }\end{array}$ & $\begin{array}{l}\text { Agenor Valadares Santos } \\
\text { Universidade Federal de Pará }\end{array}$ \\
\hline & $\begin{array}{l}\text { Adding new allergens in the World Health Organization } \\
\text { official list for Blomia tropicalis IgE-binding proteins by } \\
\text { proteomic analysis }\end{array}$ & $\begin{array}{l}\text { Eduardo Santos da Silva } \\
\text { Laboratório de Alergia e Acarologia - UFBA }\end{array}$ \\
\hline \multirow[t]{5}{*}{ 05/09 } & \multicolumn{2}{|c|}{$\begin{array}{l}\text { SESSÃO TEMÁTICA - IMUNODEFICIÊNCIA E IMUNOPATOLOGIA } \\
\qquad 13: 00-15: 00 \text { h } \\
\text { adores: Simone Garcia Macambira, Vitor Antônio Fortuna e Nívia Nonato }\end{array}$} \\
\hline & $\begin{array}{l}\text { Research of new drugs in experimental models of } \\
\text { inflammation. }\end{array}$ & $\begin{array}{l}\text { Jaime Ribeiro Filho } \\
\text { Fundação Oswaldo Cruz-CPqGM }\end{array}$ \\
\hline & Immunomodulation of Chagas Disease. & $\begin{array}{l}\text { Juliana Fraga Vasconcelos } \\
\text { Escola Bahiana de Medicina e Saúde Pública }\end{array}$ \\
\hline & $\begin{array}{l}\text { Lipid mediators in diabetes and increased susceptibility } \\
\text { to infections. }\end{array}$ & $\begin{array}{l}\text { Natália Machado Tavares } \\
\text { Fundação Oswaldo Cruz-CPqGM }\end{array}$ \\
\hline & $\begin{array}{l}\text { Physalins and their pharmacological potential as an } \\
\text { immunomodulator. }\end{array}$ & $\begin{array}{l}\text { Vinícius Pinto Costa Rocha } \\
\text { Fundação Oswaldo Cruz-CPqGM }\end{array}$ \\
\hline 05/09 & \multicolumn{2}{|c|}{$\begin{array}{l}\text { SESSÃO PLENÁRIA - PREMIAÇÕES E ENCERRAMENTO } \\
\text { 15: } 00-16: 00 \text { h } \\
\text { Moderadores: Silvia Lima Costa e Vitor Antônio Fortuna }\end{array}$} \\
\hline
\end{tabular}

OBS. $O$ acesso às Sessões do evento será através da plataforma https: //zoom.us/

O Meeting ID e o Passcode para cada Sessão será disponibilizado 30 minutos antes do início de cada Sessão em http: //www.ppgim.ics.ufba.br/ 


\title{
PESQUISADORES
}

\section{PROTEOMIC ANALYSIS OF MACROPHAGES INFECTED WHIT MYCOBACTERIUM SMEGMATIS AFTER CHOLESTEROL CONSUMPTION}

\author{
Jaqueline Batista De Lima ${ }^{1}$, Juliana Silva Cassoli ${ }^{1}$, Rafael Valadares Borges ${ }^{2}$, Chubert Bernardo Castro De Sena ${ }^{1}$, \\ Agenor Valadares Santos ${ }^{1}$ \\ 1-Universidade Federal do Pará, 2-Instituto Tecnológico Vale
}

\begin{abstract}
Tuberculosis is an infectious disease caused by Mycobacterium tuberculosis and mainly affects lungs. Alveolar macrophages are main host that form granulomas in order to contain bacterial dissemination compromising lung integrity. This work aims to study interactions between macrophages and Mycobacterium smegmatis after it was induced to consume cholesterol through minimal medium cultivation and evaluate changes caused in the host through expression profile of proteins involved in the infection. This kind of bacterium is used as an in vitro study model for tuberculosis due to its accelerated metabolism allowing rapid growth and, not pathogenicity, and per sharing cell wall structure similar to Mycobacterium tuberculosis. Cholesterol is used to mimic the conditions that bacillus undergoes in the pulmonary granulomas of tuberculosis patients. On this environment, it causes a large accumulation of host cholesterol and uses it as a source of energy and carbon for its survival, as well as to modulate changes in bioactive molecules in its cell wall, which play an important role in its pathogenicity and interaction with the cells phagocytic cells. To relate bacillus cholesterol consumption to response to macrophage infection, Mycobacterium smegmatis was cultivated in 7H9 complete medium supplemented with glycerol, minimal medium supplemented with cholesterol and in minimal medium without supplementation and after macrophages line J774A.1 was infected with these bacilli. Our results demonstrated that Mycobacterium smegmatis after consuming cholesterol is able to induce macrophages to form granuloma-like structures in vitro. Through proteomic analyzes we suggest that the consumption of cholesterol by M. smegmatis modifies the bacillus to the point where it interacts with the host cell the same way as the pathogenic strain of M. tuberculosis. Differential expression of some proteins may be causing inhibition of phagosome acidification, blocking phagolysosome fusion and production of inflammatory mediators. In addition, it may be suppressing important host metabolic pathways to modulate the immune esponse and favor survival and formation of granuloma-like structures.
\end{abstract}

Keywords: Mycobacterium, proteomics, cholesterol, infection, macrophages.

Support: CAPES

\section{NEUROIMMUNOLOGICAL CONSEQUENCES OF CORTICOSTERONE IN A DEPRESSION MODEL}

\author{
Caio Oliveira de Sá-Ferreira, Cecilia Hedin-Pereira \\ VPPCB, Fiocruz and Laboratory for Cellular NeuroAnatomy, ICB, UFRJ
}

\begin{abstract}
Major depression is the most common neuropsychiatric disorder leading even to suicide. Along with the mood changes biochemical and structural modifications occur in the brain. The etiology of depression is multifactorial, however, unbalance of the HPA axis appears to be an important factor. Since the chronic activation of the HPA axis commonly underlies depression we have developed a mouse model of high corticosterone by administration in drinking water to mimic chronic stress conditions. Mice submitted to this paradigm developed depression in 28 days of corticosterone with decrease in serotonin and dopamine levels and depressive-like behavior. Previous studies have shown alterations in hippocampal neurogenesis and myelin damage in humans. We therefore investigated whether myelin disturbances occur and the regenerative capacity of oligodendrocyte progenitors. Furthermore, we analyzed the neuro-inflammatory response by measuring cytokines (pro-inflammatory and anti-inflammatory) and the microglial population at the subventricular zone (SVZ) corpus callosum (cc) and frontal cortex. Analyzing cytokines IL-1, 6, TNF and IL-10. We showed they were not increased in the SVZ. The cellular analysis of SVZ and cc were carried
\end{abstract}


out by immunohistochemistry. Our data revealed an increase in oligodendrocyte lineage cells (Olig2+) in the SVZ concomitant to a reduction of Olig2+ cells in corpus callosum of CORTICO/ISO group. Also, electron microscopy analysis showed both reduced fiber and axon areas in the corpus callosum of CORTICO/ISO group compared to control and a myelin area reduction as well, suggesting that myelination may be compromised in the pathophysiology of major depression. Finally, we showed an increased population of microglia (Iba1+ cells) in the CORTICO/ISO group in SVZ and peri SVZ when compared with control, which reveals a possible role of microglial cells in the disorder. Hence, we show that this model promotes consistent behavioral depressive-like symptoms. Also, we described for the first time an increase in oligodendrocyte committed cells in SVZ accompanied by a decrease within the corpus callosum with cellular and myelin disturbances. Therefore, our study unveils profound cellular changes in neuronal and nonneuronal populations in a corticosterone induced depression model which are promising therapeutic targets for the disorder.

Keywords: immunohistochemistry; corticosterone; depression

Support: CAPES

\section{INFLAMMASOME ACTIVATION BY CD8 ${ }^{+}$T CELLS FROM PATIENTS WITH CUTANEOUS LEISHMANIASIS CAUSED BY LEISHMANIA BRAZILIENSIS IN THE IMMUNOPATHOGENESIS OF THE DISEASE.}

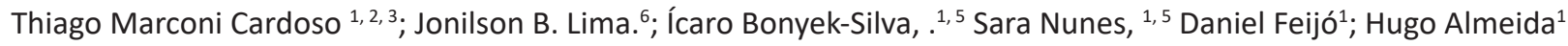
Juliana Silva. ${ }^{2}$; Aldina Barral ${ }^{1,4}$; Viviane Boaventura, ${ }^{1,5}$; Valéria M. Borges ${ }^{1}$; Dario S. Zamboni ${ }^{7}$; Lucas Pedreira de Carvalho, ${ }^{1,2,3}$; Edgar M. Carvalho ${ }^{1,2,3}$; Natalia M. Tavares, ${ }^{1,4,5}$; Cláudia Brodskyn ${ }^{1,4,5}$

1.Fiocruz-BA, Instituto Gonçalo Moniz, Salvador, Bahia, Brazil. 2.Serviço de Imunologia, Hospital Universitário Prof. Edgar Santos, Universidade Federal da Bahia, Salvador, BA, Brazil. 3.Instituto Nacional de Ciência e Tecnologia de Doenças Tropicais - INCT-DT (CNPq/MCT), Salvador, BA, Brazil. 4.Instituto Nacional de Ciência e Tecnologia de Instituto de Investigação de Imunologia (CNPq/MCT), São Paulo, SP, Brazil. 5. Faculdade de Medicina da Universidade Federal da Bahia, Salvador, Bahia, Brazil. 6.Centro de Ciências Biológicas e da Saúde, Universidade Federal do Oeste da Bahia (UFOB). 7.Faculdade de Medicina de Ribeirão Preto, Universidade de São Paulo.

ABSTRACT: Our group previously showed that $C D 8^{+} T$ cells contribute to the immunopathogenesis of Cutaneous Leishmaniasis $(\mathrm{CL})$ through the mediation of tissue injury and inflammation. Here we investigate the role of CD8T cells in the activation of the inflammasome and IL-1 $\beta$, which drives inflammation in skin lesions caused by Leishmania braziliensis. The investigation of fresh CL skin biopsies reveal ed increased expression of caspases-1 and -5 , as well as NLRP3 and AIM2. Similar increases in expression were observed in PBMCs from CL patients stimulated withL. braziliensis, and in co-culturesof $\mathrm{CD} 8^{+} \mathrm{T}$ cell sand infected macrophages. Skin biopsies of lesions, as well as co-cultures of infected macrophages and $C D 8^{+} T$ cells, show ed increased active caspase-1expression, as evidenced by ELISA, FLICA and IL-1 $\beta$ protein, in contrast to decreased expression observed through the inhibition of the CD8 cytolytic enzymes. In contrast caspase-1 or IL-1 $\beta$ production were not increased in infected macrophages or in cocultures of infected macrophages and $\mathrm{CD}^{+} \mathrm{T}$ cells. These results suggest that cytolytic process in Leishmania-infected macrophages induced by perforin and granzyme can lead to an osmotic imbalance in the cellular membrane. The consequent release of potassium triggers inflammasome activation and IL-1 $\beta$ production, contributing to the persistent inflammation seen in CL lesions.

Keywords: leishmania braziliensis, cytotoxicity, inflammosomes

Support: Fapesb and CNPq 


\title{
MICRORNAS IN NEUROINFLAMMATION: IMPLICATIONS IN NEURODEGENERATIVE DISORDERS
}

\author{
Dora Brites $^{1}{ }^{2}$ \\ ${ }^{1}$ Neuron-Glia Biology in Health and Disease, Research Institute for Medicines (iMed.ULisboa), Faculty of Pharmacy, \\ Universidade de Lisboa, Lisbon, Portugal
}

${ }^{2}$ Department of Biochemistry and Human Biology, Faculty of Pharmacy, Universidade de Lisboa, Lisbon, Portugal

\begin{abstract}
Neurodegenerative disorders, such as amyotrophic lateral sclerosis (ALS), Alzheimer's disease (AD) or Parkinson's disease, occur by neuronal degeneration (Neurocentric view) and neuroinflammation associated to astrocyte reactivity and microglia activation (Gliocentric view). Though not yet clarified what comes first, the deregulated communication between these cells at the central nervous system (CNS) are without doubt involved in disease progression. In addition, besides similarities between such disorders, there are as well pathological differences that associate to each cell response to a stimulus, its heterogeneity and regional diversity.Microglia comprise 5-10\% of the total CNS in humans and mice. They colonize the CNS early in embryonic development and are the innate immune cells of the brain. Astrocytes are at least $50 \%$ of the cells at the brain and spinal cordand provide trophic Support to neurons. Both are key players in sustaining CNS homeostasis and synapse dynamics. Changes in microglia and astrocyte transcriptomes in response to a variety of CNS pathologies were recently identified. However, due to the complexity of cell subtypes, as well as a kaleidoscope of autocrine and paracrine signaling, and their dependence of disease progression stages, it has been difficult to identify cell specific pathological effectors and their targets. Intercellular communication involves in addition to cell-to-cell contacts, signaling pathways by soluble factors and extracellular vesicles (EVs), which are released from most cells, including neurons, astrocytes, and microglia [1]. Among the molecules that are transmitted between cells, noncoding RNAs [microRNAs (miRNAs)] that circulate in the soluble form or encapsulated in EVs have a crucial role in intercellular communication at short and long distances, respectively. In this talk we will address the miRNAs more associated to the neuroinflammatory processes subsequent to astrocyte and microglia activated polarizationand we will give examples of their signature in ALS and $A D$ when using mice and human models [2, 3], as well as their potential applications for diagnosis and therapeutics.
\end{abstract}

Keywords: Neurodegenerative disorders; neuroinflammation; miRNAs.

Support: EU Joint Programme-Neurodegenerative Disease Research (JPND) and Fundação para a Ciência e a Tecnologia (FCT-JPco-fuND/0003/2015 to DB), Santa casa da Misericórdia de Lisboa (SCML - ALS Research Grant ELA2015-002 to DB), FCT (PTDC/MED-NEU/31395/2017 and LISBOA-01-0145-FEDER-031395 to DB), and in part by UID/ DTP/04138/2019 to iMed.ULisboa. [1] Brites D Glia 2020; [2] Fernandes et al Biochimie 2018; Gomes et al Exp Cell Res 2020.

\section{ADDING NEW IGE-BINDING PROTEINS OF BLOMIATROPICALIS IN THE WORLD HEALTH ORGANIZATION OFFICIAL LIST OF ALLERGENS THROUGH PROTEOMIC ANALYSIS}

\author{
EDUARDO SILVA ${ }^{1}$; IOÃO PONTE ${ }^{1}$; MÁRCIA SILVA ${ }^{1}$; CARINAPINHEIRO ${ }^{1}$;LUIS PACHECO ${ }^{1}$; FÁTIMA FERREIRA²; PETER \\ BRIZA $^{1}$; NEUZA ALCÂNTARA-NEVES ${ }^{1}$ \\ ${ }^{1}$ Laboratório de Alergia e Acarologia, Departamento de Ciências da Biointeração, Instituto de Ciências da Saúde, \\ Universidade Federal da Bahia, Salvador, Brazil; ${ }^{2}$ Department of Biosciences, University of Salzburg, Salzburg,
}

Austria;

\begin{abstract}
House dust mites (HDM) represent one of the main sources of IgE-binding proteins and risk factors for different allergic illnesses. Initially identified as a storage mite, Blomiatropicalis also constitutes a very important HDM species, whose allergens have been partially recognized by the World Health Organization and International Union of Immunological Societies (WHO/IUIS) Allergen Nomenclature Sub-committee. Other HDM species had a larger list of acknowledged allergens in comparison to B. tropicalis, mainly due to the advent of the "omics" studies, which have largely been restricted to Dermatophagoidesspp. Aim: To increase the knowledge and number of $B$. tropicalis allergens in WHO/IUIS official list through proteomic analysis. Methods: Eleven in-bred lineages of B. tropicaliswere generated from 11 unique different pregnantfemales. Their somatic extracts were analyzed and compared with a commercially
\end{abstract}


available extract by liquid chromatography tandem mass spectrometry (LC-MS/MS). After this in solution analysis, one of the extracts were analyzed by two-dimensional gel electrophoresis as well as IgEimmunoblotting using a pool of sera from B. tropicalis-sensitized patients. Spots of interest were excised and the proteins were digested with trypsin before subjecting the peptidesto LC-MS/MS and database search. All non-acknowledged isoallergens with sufficient data for WHO/IUIS recognition were sent to the subcommittee. Results: The generated breeds displayed considerable differences in the protein expression profiles, and most of the mexhibited higher content of major allergens than the commercially available extract. The most prominent allergenic protein was Blot 2 . Fourteen new isoforms and six WHO/IUIS non-recognized allergens were identifiedbyin solution analysis. In-gel digestion analysis allowed us to confirm the presence of two new allergens, and two new isoforms, among other allergens already acknowledged by WHO/IUIS. Contrarywise, three previously recognized $B$. tropicalis allergens were not found in our analyses. From the ten files sent to WHO/IUIS, four have been analyzed so far and three allergens were added to $B$. tropicalis official list. Conclusions: Inbreeding impacts allergen content and LC-MS/MS may be a useful method not only as a quality control tool for allergen extracts, but also to increase the knowledge on allergens from HDM species.

Keywords: proteome, house dust mite, immunoblotting.

Support: CAPES, project No.077/2012

\title{
DIAGNOSIS OF MALIGNANT HEMOPATHIES BY FLOW CYTOMETRY IMMUNOPHENOTYPING
}

\author{
Herbert Henrique Santos Melo \\ Serviço de hematologista do HUPES Lablmuno - UFBA
}

\begin{abstract}
Flow cytometry is a technique used as a mean of obtaining basic parameters such a size and shape. However, tecnological improvements and scientific breaktrhoughs, for example, the production of monoclonal antibodies initiated a series of changes in the laboratorial routine, that now can be used by biomedical professionals, as an example, hematological, molecular biology and others. Flow cytometry is a technique that makes possible a multiparametric analysis of blood cells, something that is possible because of the development of monoclonal antibodies and combination of them to fluorochromes, something that contributed to the process of understanding physiological changes that occur during the maturation and differentiation of all the normal elements of the hematopoietic system, similar to those that may occur during the development of pathological process. Immunopehotyping of neoplastic of hematopoietic cells not only helps the differential diagnosis and leads to the appropriate therapy but also contributes to the classification of leukemias.
\end{abstract}

Keywords: Leukemias, Flow Cytometry, Blood cells

Support: Fundação de Apoio à Pesquisa e Extensão - FAPEX 


\title{
Investigation of new drug candidates for the treatment of inflammatory diseases
}

Gustavo Marinho Miranda, Vitória Ohana Ramos e Santos, Tiago Santos Carvalho Da Rocha, Sânzio Silva Santana, Jamile de Jesus Vieira, Sètondji Cocou Modeste Alexandre Yahouédéhou, Marilda Souza Goncalves and Jaime Ribeiro-Filho* $^{*}$

INSTITUTION: Instituto Gonçalo Moniz, Fundação Oswaldo Cruz, Salvador 40296-710, Brasil

*Correspondence: jaime.ribeiro@fiocruz.br

\begin{abstract}
The inflammatory response to tissue damage can occur through different mechanisms of induction, regulation, and resolution. While inflammation is an essential process for the host defense against pathogens, failures in the resolution of this process have been associated with the development of chronic diseases that require long-term therapy. As the currently available anti-inflammatory drugs present significant therapeutic limitations, the development of novel drugs remains an extremely relevant topic. We have used both in vivo and in vitro models to investigate the anti-inflammatory potential of new compounds, with an emphasis on natural products such as curine, an alkaloid that has demonstrated antiallergic, analgesic, and immunomodulating properties in different models of inflammation. Curinewas found to inhibit leukocyte recruitment activation, which was associated with inhibition of inflammatory mediator production both in vivo and in vitro. Curine also inhibited allergic symptoms in murine models of asthma, anaphylaxis, and skin allergy. This alkaloid also presented analgesic effects that were associated with anti-inflammatory mechanisms (in particular, inhibition of $\mathrm{PGE}_{2}$ production), and evidence has demonstrated that the mechanism of action by curine depends, at least partially, on inhibition of a calcium-dependent response. Our research has also evaluated the use of carrier nanoparticles such as cyclodextrins to improve the physicochemical and biopharmaceutical properties of natural products such as essential oils and their isolated components. In Conclusion, natural products represent promising sources of bioactive compounds with the potential to be used in anti-inflammatory drug development.
\end{abstract}

Keywords (3): Inflammation. Drug development. Natural products

Support: Instituto Gonçalo Moniz, Fundação Oswaldo Cruz

\section{IMMUNOMODULATION IN CHAGAS DISEASE}

\author{
Juliana Fraga Vasconcelos \\ Escola Bahiana de Medicina e Saúde pública
}

\begin{abstract}
Chronic chagasic cardiomyopathy is a leading cause of heart failure in Latin American countries, being associated with intense inflammatory response and fibrosis. Currently, there is no drug capable of improving the established CCC, being the inflammatory response an important target. Here we are going to discuss the main immunomodulation strategies for chagasic myocarditis that occur in the chronic phase of the disease, with emphasis on the role of pro and anti-inflammatory mediators.
\end{abstract}

Keywords: CCC. Inflammation. Fibrosis.

Support: Escola Bahiana de Medicina. 


\title{
HOW THE DEVELOPMENT OF A RECOMBINANT BCG VACCINE AGAINST BORDETELLA PERTUSSIS LEAD TO AN IMPROVED TUBERCULOSIS VACCINE.
}

\author{
Luciana Cezar de Cerqueira Leite \\ Instituto Butantan
}

\begin{abstract}
New strategies against Mycobacterium tuberculosis (Mtb) have become a global priority, since Mycobacterium bovisBacilleCalmette-Guérin (BCG), has shown variable results of protective efficacy and there is a rising frequency of multi-drug resistant (MDR) Mtb strains. We have previously developed a recombinant BCG expressing the S1 subunit of pertussis toxin as a neonatal vaccine against Whooping cough. These studies revealed the immunomodulatory properties of toxin derivatives, leading to the development of arBCGstrain expressing the adjuvant LTAK63 (rBCG-LTAK63). This strain has been shown to be more protective than BCG against tuberculosis (TB) using an intratracheal challenge animal model. Our results show that the rBCG-LTAK63 induces enhanced innate immunity, increased Th1responses in the lungs and Th17 long-term immune responses as compared to BCG wild type.
\end{abstract}

Keywords: Recombinant BCG, Pertussis, Tuberculosis

Support: FAPESP, BNDES.

\section{PLATFORMS FOR COVID-19 DIAGNOSISANDMONITORING.}

Luiz R. Goulart, Thulio M. Cunha, Mário M. Martins, Anderson R. Santos, Murillo. G. Carneiro e Robinson SabinoSilva.

\author{
Federal University of Uberlandia
}

\begin{abstract}
Novel alternatives for disease diagnostics and monitoring have been developed based on biophotonics and mass spectrometry platforms. We will present two technologies that are reagent-less, used specifically in the COVID-19 pandemic, that not only integrate artificial intelligence tools, but also Big Data applications. Spectroscopic and spectrometric signatures can define new strategies for approaching personalized medicine as well as public policies, providing simplified diagnosis and monitoring of complex and chronic-degenerative diseases. The new disruptive platforms will be discussed regarding their impact on the diagnostic market.
\end{abstract}

Keywords: Covid-19, Reagent-less diagnostics, Biophotonics.

Support: ImunoscanEngenhariaMoleculatLtda, Federal University of Uberlandia, and Ministry of Science and Technology - FINEP.

\section{"OMICS" AS A TOOL FOR CONTROL OF INFECTION BY AEROMONASHYDROPHILA IN AQUATIC ORGANISMS}

\author{
Mateus Matiuzzi da Costa $^{1}$, Ruan Emmanuell Franco de Abreu \\ 1-Federal University od São Franscisco River Valley; Federal Rural University of Pernambuco
}

\begin{abstract}
Fish farming represents one of the fastest growing agricultural activities in Brazil. Super intensive production systems provide stressful situations to animals, causing advantage to opportunistic pathogens to explore immunosuppression to institute the disease process. Aeromonashydrophilaare distributed naturally in diverse aquatic ecosystems, where they are easily isolated from diseases cases in aquatic organisms. In these animals the infections by these opportunistic pathogens are associated to hemorrhagic lesions and septicemia. Metagenomic, transcriptomic, and metabolomic methods, colloquially called "omics, " are approaches that can better inform the relationship among pathogens and its host defenses. The integration of multiple omic data using bioinformatic and statistical tools and in
\end{abstract}


silico models are important to allow the development of prophylaxis strategies. As result of in vitro study identified that signals from environmental (ammonia concentration) has effects in $A$. hydrophilavirulencegene expression, as fla linked to motility and biofilm formation. In vivo study involving $A$. hydrophila infection in Nile Tilapia by skin transcriptome analysis demonstrated the role of innate immunity on the initial infection of $A$. hydrophila and the contribution of iron regulation in the disease and mortality process.

Keywords: Fish, RNA-Seq, Vaccine.

Support: CAPES, FACEPE

\title{
ANTI-INFLAMMATORY PROPERTIES DISPLAYED BY A NOVEL BIFLAVONOID REPRESENT A PROMISING DISEASE-MODIFYING THERAPY FOR DEMYELINATING DISEASES
}

\author{
Monique Marylin Alves de Almeida \\ Universidade Federal da Bahia/Universityof Portsmouth-UK
}

\begin{abstract}
Inflammation and myelin dysfunction play a significant role in the pathogenesis of various neurodegenerative diseases. Therefore, there is a critical need to develop more effective therapies for the treatment of these disorders. In this study, we examined the effect of the flavonoid agathisflavone on neuroinflammation and demyelination, which are hallmarks of demyelinating diseases, such as multiple sclerosis. Agathisflavone showed an important anti-inflammatory response in the different models approached, and, consequently, it accelerated remyelination, an effect that seems to be attributed to its affinity for binding to estrogen receptors.
\end{abstract}

Keywords: Flavonoids; Demyelination; Inflammation.

Support: This work was Supported by the Multiple Sclerosis Society (AB, FP-Award Reference: 40) and the Biological Sciences Research Council (AB, Grant number: BB/M029379/1). This work was also Supported by the Coordination of Personnel Improvement of Higher Level (CAPES, Process № 88881.117666/2016-01, and PDSE Scholarship № 88881.133939/2016-01), Foundation for Research Support of the State of Bahia (Process № INT 0016/2016) and the National Council for Scientific and Technological Development (CNPq, Scholarship № 140333/2016-9, PostGraduation Program in Immunology- Federal University of Bahia-Brazil).

\section{MEDIADORES LIPÍDICOS NO DIABETES E AUMENTO DA SUSCEPTIBILIDADE À INFECÇÕES.}

Bonyek-Silva, Icaro; Nunes, Sara; Santos, Reinan; Lima, Filipe; Lago, Alexsandro; Silva, Juliana; Carvalho, Lucas; Arruda, Sergio; Serezani, Henrique; Carvalho, Edgar; Brodskyn, Claudia ; Tavares, Natalia

Instituto Gonçalo Moniz (IGM) - Fiocruz/BA

ABSTRACT: Poorly controlled diabetes mellitus leads to several comorbidities, including susceptibility to infections. Hyperglycemia increases phagocyte responsiveness, however immune cells from people with diabetes show inadequate antimicrobial functions. We and others have shown that aberrant production of leukotriene B4 (LTB4) is detrimental to host defense in models of bacterial infection. Here, we will unveil the consequences of high glucose in the outcome of Leishmaniabraziliensis skin infection in people with diabetes and determine the role of LTB4 in human phagocytes. We show that diabetes leads to higher systemic levels of LTB4, IL- 6 and TNF- $\alpha$ in cutaneous leishmaniasis. Only LTB4 correlated with blood glucose levels and healing time in diabetes comorbidity. Skin lesions of people with leishmaniasis and diabetes exhibit increased neutrophil and amastigote numbers. Monocyte-derived macrophages from these individuals showed higher L. braziliensis loads, reduced production of Reactive Oxygen Species and unbalanced LTB4/PGE2 ratio. Our data reveal a systemic inflammation driven by diabetes comorbidity in opposition to a local reduced capacity to resolve L. braziliensis infection and a worse disease outcome.

Keywords: Diabetes, human leishmaniasis, lipid mediators.

Support: FAPESB, CNPq, CAPES. 


\title{
OMICS APPLIED TO THE STUDY OF PATHOGENIC MICROORGANISMS
}

\author{
Pablo I. P. Ramos \\ Instituto Gonçalo Moniz, FIOCRUZ-Bahia
}

\begin{abstract}
In this talk, I will explore the tremendous impacts of high-throughput sequencing efforts to the understanding of the biology of pathogenic organisms, particularly multidrug-resistant bacteria. Some examples of bacterial isolates whose genomes were determined in Brazil will be given, and how thisintegrated understanding may lead to novel ways to counter these pathogenic organisms will be briefly presented.
\end{abstract}

Keywords: genomics; bioinformatics; bacteria; pathogens

Support: Instituto Gonçalo Moniz, FIOCRUZ-Bahia

\section{RECOMBINANT PROTEINS FOR HCV DIAGNOSTIC EVALUATION AND / OR MONITORING}

\author{
Costa, Paulo Inácio da; Kenfe, Flávia Regina \\ Faculdade de Medicina de Ribeirão Preto Universidade do estado de São Paulo
}

\begin{abstract}
The hepatitis C virus (HCV) is an enveloped virus of about 50 to $70 \mathrm{~nm}$ in diameter, positive strand RNA, and belongs to the genus Hepacivirus and the family Flaviridae. The detection and quantification of the core antigen, HCV nucleocapsid protein, has been successful in many trials and is considered a marker of viral replication, since it presents a sequence of highly conserved amino acids, giving it high sensitivity and specificity. The E2 protein is an envelope glycoprotein of HCV with 11 glycosylation sites, most of these well-conserved, making it a target antigen. The aim of this study was to develop high sensitivity, low cost diagnostic methods for HCV which could be used for serological screening. The genomic regions encoding the core (part $136 \mathrm{aa}$ ) and E2 proteins of HCV were expressed in E. coli Rosetta strain, cloned in expression vector pET-42a, and induced with 0.4 mM IPTG, producing recombinant proteins fused to GST protein (glutathione S-transferase), which were then purified by affinity chromatography. The immunoreactivity was assessed by Western blot, Slot Blot and the developed and improved diagnostic methods (enzyme-linked immunosorbent assay (ELISA) capture and indirect, immunoblotting and immunochromatographic). The methods developed were more sensitive and specific using the mixture of the recombinant proteins fused to GST (core + E2).
\end{abstract}

Keywords: Hepatite C; Proteínas ;Teste imunoenzimático

Support: Fundação de Amparo à Pesquisa do Estado de São Paulo (FAPESP)

\section{CHALLENGES IN SCHISTOSOMIASIS CONTROL}

SANTOS RA; DE JESUS KEM; TABAJARA Y; SILVA TM; MACEDO MN; FIALHO TRS; OLIVEIRA BSS; CASAES AC; PINHEIRO E; GRATIVAL B; FRANCISCO MVLO; CARDOSO LS; PITANGA TN; GONÇALVES MS; SIQUEIRA IC; OLIVEIRA RR

$$
\text { GONÇALO MONIZ INSTITUTION - FIOCRUZ-BA }
$$

\footnotetext{
ABSTRACT: Schistosomiasis is a parasitic disease of great relevance to public health. In Brazil, the disease is caused by Schistosomamansoni. The Point-Of-Care Circulating Cathodic Antigen (POC-CCA), is a rapid test for the diagnosis of schistosomiasis in urine. Since the POC-CCA is still being studied in Brazil, it is necessary to evaluate factors that may interfere with the test performance. Our goal is to investigate whether physicochemical factors in urine may interfere with the result of POC-CCA. Residents of rural areas in the municipality of Conde-BA were included, who provided samples of feces and urine, for making two Kato-Katz slides and performing POC-CCA and urine tape. Of the 189 individuals included in the study, 116 (61.4\%) were positive for Kato-Katz schistosomiasis. A total of 89 (76.7\%); $22(19.0 \%)$ and 5 (4.3\%) individuals had low, medium and high parasitic loads, respectively. POC-CCA positivity was observed in 102 (54.0\%) urine samples, with a kappa agreement of 0.267 between Kato-Katz and POC-CCA. As Kato-
} 
Katz has low sensitivity, but specificity close to $100 \%$, we decided to evaluate the urine characteristics of the 41 individuals (21.7\%) who presented false-negative results for POC-CCA. It was observed that almost all individuals who present false-negative results for POC-CCA have low parasitic load $(87.8 \%, p<0.01)$. Likewise, $79.2 \%$ of the falsenegative results were obtained from urines that showed high density (>1025 Kg / m3; $p<0.0001$ ). All individuals who had blood in the urine $(n=2)$ had a false negative result. While of the individuals who had leukocytes in the urine ( $n$ $=4$ ), $75 \%$ were false-negative for POC-CCA. We conclude that the low parasitic load and physico-chemical changes in the urine may interfere with the result of the POC-CCA. This fact allows us to evaluate potential limitations in the performance of the method that can lead to failure to eradicate the disease, by covering up individuals who are truly positive.

Keywords: Schistosomiasis; POC-CCA; diagnosis

Support: FAPESB, CNPq, PGPAT, IGM-FIOCRUZ/BA

\title{
SCHISTOSOMAMANSONI SURFACE PROTEINS: THEIR ANTI-INFLAMMATORY PROPERTIES AND ROLE AS POTENTIAL MOLECULES FOR THERAPEUTICS
}

\author{
Sergio C. Oliveira ${ }^{1,2,{ }^{*}}$, Luciana S. Cardoso ${ }^{2,3}$, Edgar M. Carvalho ${ }^{2,4}$, Fabio S. Mambelli ${ }^{1}$, Suellen B. Morais ${ }^{1}$, Mariana \\ T.Q. de Magalhães ${ }^{1}$, Barbara C. Figueiredo ${ }^{5}$ \\ ${ }^{1}$ Departamento de Bioquímica e Imunologia, Instituto de Ciências Biológicas, Universidade Federal de Minas Gerais, \\ Belo Horizonte, Minas Gerais, Brazil.
}

${ }^{2}$ Instituto Nacional de Ciência e Tecnologia em Doenças Tropicais (INCT-DT), Salvador, Bahia, Brazil. ${ }^{3}$ Departamento de Análises Clínicas e Toxicológicas, Faculdade de Farmácia, Universidade Federal da Bahia, Salvador, Bahia, Brazil. ${ }^{4}$ Instituto Gonçalo Moniz, FIOCRUZ, Salvador, Bahia, Brazil. ${ }^{5}$ Departamento de Bioquimica e Biofisica, Universidade Federal da Bahia, Salvador, BA, Brazil.

\begin{abstract}
Schistosomamansoni is one of the main agents of schistosomiasis, which is the most important human helminthic infection in terms of global morbidity and mortality. Although schistosomiasis represents a major public health problem in endemic countries, evidences show that $S$. mansonidownregulates inflammatory responses in many diseases. Fortunately, the control of inflammatory responses is extended to pathogen-derived antigens, leading us to study two important molecules S. mansoni Sm29 and the Kunitz type protease inhibitor (SmKI-1). We have previously demonstrated that $\mathrm{rSm} 29$ reduces TNF- $\alpha$ and IFN- $\gamma$ production and increases regulatory T cells in cutaneous leishmaniasis (CL) patients. Sm29 also acts in dendritic cells (DC) increasing IL-10 and IL-10 receptors expression in $\mathrm{CL}$ patients. We recently developed a gel formulation containing $\mathrm{rSm} 29$ and gold nanoparticles. In preliminary experiments in patients, we showed that $\mathrm{rSm} 29$ had no clinic or laboratory adverse reactions. We showed that the combination of glucantime (Sanofi-Aventis) plus topical Sm29 cured $87.5 \%$ of patients by day 90 while $57.1 \%$ of patients who use glucantime plus placebo cured their lesions. Our hypothesis is that the exaggerated inflammatory response induced by L. braziliensis limit and delays the response to glucantime therapy and that $\mathrm{rSm} 29$ combined with glucantime will accelerate the cure of $\mathrm{CL}$ patients. Regarding SmKI, our study has demonstrated this molecule plays an essential role in neutrophil elastase (NE) binding blockage, in neutrophil influx and as a potential anti-inflammatory molecule. Further, we demonstrate that SmKI-1 possesses an anti-inflammatory potential in three different murine models of inflammatory diseases: acetaminophen (APAP)-mediated liver damage, gout arthritis, and pleural inflammation in response to carrageenan. In these inflammatory disease models, we evaluated SmKI-1 effect on neutrophil and our results demonstrate this molecule is able to inhibit neutrophil migration and function, regulating inflammation.
\end{abstract}

Keywords: Schistosomamansoni, inflammatory responses, neutrophil

Support: FIOCRUZ, CAPES 


\title{
PHYSALINS AS IMMUNOMODULATORY DRUGS
}

\author{
Vinicius Pinto Costa Rocha ${ }^{1}$; Ivone Maria Ribeiro²; Therezinha Tomassini Coelho Barbosa ${ }^{2}$ and Milena Botelho \\ Pereira Soares ${ }^{1}$
}

\section{1- Fundação Oswaldo Cruz. Centro de Pesquisa Gonçalo Moniz. Salvador, BA, Brasil}

\section{2- Fundação Oswaldo Cruz. FarManguinhos. Rio de Janeiro, RJ, Brasil}

\begin{abstract}
Physalins are secosteroids purified from Physalisangulata. Our group has demonstrated the immunomodulatory activity of these molecules in different immuno-mediated diseases models. These molecules are able to reduce the activity of macrophages, the production of TNF- $\alpha$ and nitric oxide, and protect the animals in a model of endotoxic shock mediated by LPS. Moreover, physalins inhibit lymphocytes activation and xenograft rejection. Recently, we demonstrated that physalin $\mathrm{F}$ reduces the production on IL-1 $\beta$, in a caspase- 1 independent pathway, and the production of IL-12, by peritoneal macrophages. IL-10 is increased after physalin F treatment. However, the treatment of IL-10\% animal did not block the immunomodulatory effect, suggesting that not only IL-10 production induced by physalin $\mathrm{F}$ is important to modulate the immune response. Because, physalins are steroidal molecules, our hypothesis is that physalin $\mathrm{F}$ may act through nuclear receptors. To this end, we performed a receptor translocation assay to evaluate the activation of glucocorticoid (GR) and vitamin-D (VDR) receptors. Our results shown that physalin F does not activates GR, but induces VDR translocation to the nuclei. Further research is ongoing to validate the VDR as the pharmacological target of physalin F as well as to evaluate the genes modulated by this molecule.
\end{abstract}

Keywords: Physalis angulate. Physalin. Immunomodulatory

Support: Fundação Oswaldo Cruz; Conselho Nacional de Desenvolvimento Científico e Tecnológico. 


\title{
DISCENTES
}

\section{A MISSENSE-TYPE VARIANT, RS41347648, DECREASES RISK OF ATOPY IN BRAZILIANS BUT NOT ASTHMA}

\author{
Talita S. Jesus ${ }^{1}$, Helena Pitangueira' ${ }^{1}$, Gabriela P. Pinheiro ${ }^{2}$, Álvaro A. S. Cruz ${ }^{2}$, Ryan S. Costa ${ }^{1}$, Camila A. Figueiredo ${ }^{1}$ \\ ${ }^{1}$ Laboratório de Imunofarmacologia e Biologia Molecular, Instituto de Ciências da Saúde, Universidade Federal da \\ Bahia, Bahia, Brasil; '2Programa para o Controle da Asma na Bahia (ProAR), Universidade Federal da Bahia (UFBA), \\ Bahia, Brasil.
}

Introduction: Asthma is a chronic disease of lungsand it is frequently associatedwith aTh2 inflammation where IgE and inflammatory mediators are released in the presence of common allergens and among the mediators involved are the cysteinylleukotrienes (CysLTs) - LTC4, LTD4 and LTE4. CysLTs are linked to bronchoconstriction, airway hyperresponsiveness, and eosinophilia. CysLTs can bind to the Cysteinyl leukotriene receptor type 2 (CysLTR2) and activate the symptoms described above.Thus, polymorphisms in CYSLTR2may be associated with asthma phenotypes, especially those related to the Th2 pathway. In this study, we explored the role of a rare variant, rs 41347648 which has been already linked to asthma and atopy in several populations but never described in Brazilians. Objective: To evaluate the association between a rare genetic variant in CYSLTR2 (rs41347648) with asthma and atopy in a Brazilian cohort. Methods: Genotyping was performed using an Illumina panel and carried out in 1, 096 participants from Programa de Controle da Asmana Bahia(ProAr). Logistic regressions for asthma and atopy markers (skin prick test) were performed using PLINK 1.9 software adjusted for sex, age, smoking, BMI (body mass index) and ancestry markers. Results and Discussion: This is a missense-type variant where the amino acid valine is replaced by a methionine. The frequency of the variant in the study population is very low only $1.23 \%$, despite that the $G$ allele of the variant was negatively associated in the dominant model with skin prick test to at least one mite (OR: 0.23 : 0.07-0.73) and negatively associated with skin prick test toat least one of the main allergens in our region (0.45: 0.12 0.73). This result was different from other studies where this same variant was correlated with a higher risk of atopy. The variant was not associated with asthma and other atopic markers, possibly due to low frequency. Conclusion: The variant was negatively associated with atopy markers, however further studies conducted witha larger number of subjectsare needed in order to increase the statistical power and investigate the real impact of this variant on asthmatic individuals.

Keywords: Asthma, rs41347648, CYSLTR2.

Support CAPES, CNPq, FAPESB, PROAR.

\section{AGATHISFLAVONE INCREASES THE ASTROCYTIC POPULATION IN THE SUBVENTRICULAR ZONE AND MODULATES REACTIVE GLIOSIS IN VIVO}

$\underline{\text { Juliana Helena Castro e Silva }} \stackrel{1}{1}$, Francesca Pieropan ${ }^{2}$, Andrea Rivera ${ }^{2}$, Arthur Morgan Butt ${ }^{2}$, Victor Diogenes Amaral da Silva, Silvia Lima Costa ${ }^{1}$; Department of Biofunction, Health Sciences Institute, Federal University of Bahia, Brazil;

${ }^{2}$ School of Pharmacy and Biomedical Sciences, University of Portsmouth, United Kingdom.

Introduction: The Subventricular Zone (SVZ) is a neurogenic niche that persists in adult life where neural stem cells (NSCs) give rise to interneurons and glial cells in the brain, and the neurogenesis in this niche is stimulated by growth and transcription factors and occurs after brain injury, for example. In brain injury and other neuroinflammatory conditions, a coordinated inflammatory response of glial cells is a common pathological finding known as reactive gliosis, a factor that might impair the neuroregeneration. In this context, immunoregulatory drugs can be adjuvant therapies. Objectives: The aim of this work was to evaluate the potential of the neuroprotective biflavonoidagathisflavone in modulating neurogenic populations in the Subventricular Zone (SVZ) and modulating the reactive gliosis in vivo. Methods: For this purpose, C57/BL6 hGFAP-EGFP aged 8 to 11 days (P8-P11) were subjected to two intracerebroventricular injections per day with agathisflavone (100 $\mu \mathrm{M}$ in $2 \mu \mathrm{L}$ PBS / injection) or 
PBS + 0.1\% DMSO (vehicle) ( $2 \mu \mathrm{L} /$ injection) for 3 days. On the 4th day, the animals were sacrificed and brain fixed tissue analyzed by immunohistochemistry to characterize astrocytic (hGFAP-EGFP+ or GFAP') and young proliferating migratory neurons $\left(\mathrm{DCX}^{+} \mathrm{Ki} 67^{+}\right.$) response in the SVZ and astrocytic and microglial (Iba-1, CD206 $\left.{ }^{+}, \mathrm{CD} 16 / 32^{+}\right)$response in the in injured and uninjured cortical regions. Results and Discussion: The results showed that animals treated with agathisflavone presented an increased number of hGFAP-EGFP astrocytes in the SVZ domains (dorsal, lateral and horn) without, however, inducing a significant change in the number of proliferating migrating neurons. Additionally, the injection of agathisflavone induced a reduction in the expression of the GFAP protein in the cortical region of the lesion caused by injections of the flavonoid or PBS + DMSO only (control), a marker of astrocytic reactivity. In this region, as well as the non-lesioned site, treatment with agathisflavone also induced a reduction in the number of microglia altered the expression of microglial reactivity markers. Conclusions: Together with previous work, our data indicates that agathisflavone can be a potential agent to treat brain disease controlling gliosis and favoring neural tissue regeneration.

Keywords: agathisflavone; subventricular zone (SVZ); neurogenesis; reactive gliosis.

Support: This work was partly Supported by Bahia State Research Foundation (FAPESB) and the National Council for Scientific and Technological Development (CNPq). The authors thank to Coordination for the Improvement of Higher Education Personnel for MPhil fellowships to JHCS. AMB received Support from the Multiple Sclerosis Society and the Biological Sciences Research Council.

\section{ANTIGENIC REACTIVITY OF RPKNG, RSPAC, RSODC AND RNANH IN A GOAT AND SHEEP SERUM}

Ramon Mendes dos Santos ${ }^{\frac{1,2}{2}}$, Silvana B. Marchioro ${ }^{1,6}$, Caio Lopes Borges Andrade ${ }^{1,2}$, Rogério Conceição Reis ${ }^{1,2}$, Maria Izabel Cerqueira ${ }^{1,3}$, Hévlyn Ribeiro de Araújo ${ }^{1,3}$, Marcos Borges Ribeiro ${ }^{1,4}$, Roberto Meyer ${ }^{1,5}$, Songelí Menezes Freire $^{1,6}$

1 - Membro do Laboratório de Imunologia e Biologia Molecular (LABIMUNO) da UFBA, Bahia / Brasil. 2 - Aluno do Programa de Pós Graduação em Imunologia PPGIm. 3 - Aluno da Universidade Federal da Bahia. 4 - Professor Assistente da UFBA (UFBA). 5 - Professor Titular da UFBA. 6 - Professora Adjunto da UFBA.

This work was carried out at the Laboratório de Imunologia e Biologia Molecular (Labimuno) of the Universidade Federal da Bahia (UFBA), Bahia-Brazil

Introduction: Corynebacterium pseudotuberculosis is the gram positive bacillus which causes caseous lymphadenitis $(\mathrm{CL})$, disease characterized by cutaneous granuloma formation. This disease causes significant socioeconomic losses in the northeast region of Brazil. The search for biomolecules that can be used for the efficient diagnosis and vaccine to $\mathrm{CL}$ is necessary for the control of this diseases.

Objectives: Evaluate the antigenic potential of $\mathrm{rSodC}, \mathrm{rPknG}, \mathrm{rNanH}$ and $\mathrm{rSpaC}$ in serum of sheep and goat experimentally infected with three $C$. pseudotuberculosis strains.

Material and Methods: Twenty six animals were experimentally infected with $1 \times 10$ e 7 cells of three different $C$. pseudotuberculosis strains: CAP76 or CAP21 to infect goats and VD57 to infect sheep. Sera from whole blood was collected at 0, 14, 60 and 180 or 190 days after infection. For expression of SodC, PknG, NanH and SpaC recombinant proteins, a commercial expression vector of the "pD444- $\mathrm{NH}$ Bacterial Expression Vectors" line marketed by DNA2.0 IncUSA was used. Recombinant plasmids were transformed into E. coli BL21 Star and purified using affinity chromatography. Purified recombinant proteins were submitted to $12 \%$ SDS-PAGE, then Western blot performed for the antigenicity reaction with sheep or goat pools sera and anti-goat or sheep IgG-peroxidase-conjugated-antibody (Sigma, EUA) diluted at ratio according established protocols. Revelation with 4-chloro- $\alpha$-naphthol.

Results and Discussion: All recombinant proteins were expressed and successfully purified with the bands on the gel corresponding to the molecular weight of the proteins. The antigenicity reaction revealed that sera from goat infected with CAP21 and CAP76 strains were able to recognize the rSodC and rPknG proteins. This reaction were detected at 14 days after infection remaining at least until 180 or 190 days. While sera from sheep infected with VD57 strain recognized only the $\mathrm{rSodC}$ protein. No reaction was observed with the proteins $\mathrm{rNanH}$ and $\mathrm{rSpaC}$ and with animals serum from the control group (not infected). Although there is availability of in house $\mathrm{CL}$ diagnosis test 
it is limitations, the SodC and also PknG can be useful in more reliable protocols.

Conclusions: $\mathrm{rSodC}$ is a good candidate to be used in the diagnosis test for infection by $C$. puseudotuberculosis in sheep and goats serum samples.

Keywords: Corynebacterium pseudotuberculosis, SodC, PknG, caseous lymphadenitis, immunoreactivity antigenicity

Support: Laboratório de Imunologia e Biologia Molecular (Labimuno), Fundação de Apoio à Pesquisa e à Extensão (FAPEX), Coordenação de Aperfeiçoamento de Pessoal de Nível Superior (CAPES)

\title{
ASSESSMENT OF THE VIABILITY OF CORYNEBACTERIUM PSEUDOTUBERCULOSIS UNDER DIFFERENT STRESS CONDITIONS
}

\author{
Flávia Martins da Silva ${ }^{1}$, Suzana T. Cunha Lima², Roberto Meyer ${ }^{3}$ \\ ${ }^{1}$ Doctoral Student of the Postgraduate Program in Immunology - Institute of Health Sciences, UFBA, Salvador, \\ Bahia, Brazil, '2Adjunct Professor, Department of Biointeraction - Institute of Health Sciences, UFBA, Salvador, \\ Bahia, Brazil, ${ }^{2}$ Adjunct Professor, Researcher and Coordinator of the Bioprospecting and Biotechnology Laboratory \\ (LaBBiotec) of the Institute of Biology / UFBA, Salvador, Bahia, Brazil, ${ }^{3}$ Professor, Department of Biointeraction - \\ Institute of Health Sciences, UFBA, Salvador, Bahia, Brazil. ${ }^{4}$
}

Introduction: This work deals with studies related to Corynebacterium pseudotuberculosis, a intracellular bacteria that is the etiologic agent of Caseous Lymphadenitis in goats and sheep. This disease harms meat, milk and wool production in several countries, including Brazil. However, studies that searches for identification of molecular factors involved in virulence and pathogenicity during the infection that promotes resistance to

Severals tresses found in host are still scarce. The discovery of the antigenic properties of proteins may help tounder stand the pathogenicity and factors related to resistance of $C$. pseudotuberculosis. Heat shock proteins (HSPs) have demonstrated an important role of these molecules in increasing microbial resistance under stress conditions during infection, as well as being immunologically important because they are recognized by the host and there fore capable of inducing cellular and humoral immunity response in mammals. Objectives: The aim of this research was to identify and evaluate the expression of possible genes of HSPs in C. pseudotuberculosis that could contribute to understand the virulence and pathogenicity mechanisms of this pathogen. Methods and Results: Different stress conditions were used in vitro to evaluate $C$. Pseudotuberculosisresistance. Cultivationunder stress conditions of three different trains used: T1 (attenuated), ER1409 (virulent) and CapJ4 (76) (strong biofilm producer). One colony from each strain was seeded in solid BHI, and from it, pre-inocula in $20 \mathrm{~mL}$ of liquid BHI medium plus Tween ${ }^{\circledR} 80$ at a final concentration of $0.05 \%$ were prepared. After 24 hours of grow that $37^{\circ} \mathrm{C}$ undershaking, part of the cultures were re-inoculated (1: 100$)$ in $100 \mathrm{ml} \mathrm{BHI}$ medium plusTween ${ }^{\circledR} 80$ (0.05\% final) and incubated again at $37^{\circ} \mathrm{C}$. The culture was monitore duntil the beginning of the stationary phase $(0 D 600 \mathrm{~nm}=0.2)$. The samples were centrifuged and the bacterial pellets were induced to the acid stress in $\mathrm{BHI}$ medium add edof (hydrochloricacidwith $\mathrm{pH}$ adjusted to 5.0 and 6.0), the thermal stress ( $40^{\circ} \mathrm{Cand} 43^{\circ} \mathrm{C}$ ), the osmotic stress increasing concentrations $\mathrm{NaCl}(1 \mathrm{M}$ to $2 \mathrm{M}$ ) the nitrosative stress at increasing concentrations $(5 \mathrm{mM}$ to $7 \mathrm{Mm})$ and oxidative stress at increasing concentrations of $\mathrm{H} 2 \mathrm{O} 2(10 \mathrm{mM}$ to $40 \mathrm{mM})$. Strains were submitted to stress for 15,30 and 45 minutes. All conditions were evaluated in triplicate. The viability oft hestrains was evaluated under stress conditions on BHI agar for 48 hours and cell grow thunder optical densitometry using $10^{-4}, 10^{-5}$ and $10^{-6}$ serial dilutions. Conclusion: As preliminary results, the obtained optical density readings point to a stabilization of growth when the bacteriais subjected to acid, temperature, osmotic and oxidative stress for the ER1409 and CapJ4 (76) strains. These strains were more resistant to the imposed medium, despite presenting a slight loss of replicative potential, which was observed through the survival rate in relation to the control sample. However, these conditions did not inhibit bacterial growth, demonstrating the adaptive potential of $C$. pseudotuberculosis to stress response in adverse conditions. This knowledge is important for understanding the molecular mechanism occurring in the infectious process in goats and sheep.

Keywords: Caseous Lymphadenitis; Corynebacterium pseudotuberculosis; Hsps; Stress. 


\title{
ASSOCIATION OF RETN GENE POLYMORPHISM WITH ASTHMA - EFFECT MODIFICATION BY ABDOMINAL OBESITY
}

\author{
Raísa S. Coelho ${ }^{1,2}$, Ana Paula C. Melo ${ }^{1,2}$, Hátilla dos S. Silva ${ }^{2}$, Helena M. P. Teixeira ${ }^{1,2}$, Jamille S. Fernandes ${ }^{3,4,5}$, \\ Gabriela P. N. Pinheiro ${ }^{5}$, Adelmir S. Machado ${ }^{5}$, Álvaro A. Cruz ${ }^{5}$, Camila A. Figueiredo ${ }^{1,2}$, Ryan S. Costa ${ }^{1,2}$. \\ ${ }^{1}$ Programa de Pós-Graduação em Imunologia, Instituto de Ciências da Saúde (ICS), Universidade Federal da \\ Bahia (UFBA), Salvador, Bahia, Brasil;'2 Laboratório de Imunofarmacologia e Biologia Molecular (IMUNOBIO), \\ UFBA, Salvador, Bahia, Brasil; ${ }^{3}$ Centro de Ciências Biológicas e da Saúde, Universidade Federal do Oeste da Bahia, \\ Barreiras, Bahia, Brasil; ${ }^{4}$ Serviço de Imunologia, Hospital Universitário Professor Edgard Santos, Universidade \\ Federal da Bahia (UFBA), Salvador, Bahia, Brasil; ${ }^{5}$ ProAR - Núcleo de Excelência em Asma, UFBA, Salvador, Bahia, \\ Brasil.
}

Introduction: Asthma and obesity are chronic diseases with increasing prevalence that, besides environmental and genetic factors, have inflammation as a common link. Accordingly, cytokines secreted by adipose tissue cells with receptors expressed in the lung are pointed at the link between the immune regulation involved in the pathogenesis of both diseases. Variations in the RETN, have been associated with their unbalanced serum levels and consequent metabolic dysfunction that promote impact on asthma. Objectives: To investigate the association between variants in the RETN with asthma and how the abdominal adiposity modifies that association. Material and Methods: The study involved 796 individuals, followed by ProAR. Asthma was defined according to GINA and abdominal obesity was defined by WHtR, according to WHO. Genotyping was performed using Illumina Infinium kit Multi-Ethnic AMR/AFR-8. Logistic regression was performed to identify associations between variants with asthma, stratifying the population by WHtR. Results and Discussion: After adjustment for confounding parameters, no significant associations were observed in the general study population and in individuals without abdominal obesity. However, in individuals with abdominal obesitythe rs3745367 (allele G) was negatively associated, in the dominant model, with asthma (OR: $0.6395 \% \mathrm{IC}: 0.41-0.98$ ). The $\mathrm{G}$ allele is also associated with lower gene expression of resistin in lung tissue, according to GTex.The GG genotype has recently been associated with a lower serum resistin level. We believe that adiposity acts as an inflammatory trigger, activating the genetic predisposition for the overproduction of resistin, which contributes to the increased risk of airway inflammation, a hypothesis that is related to the risk allele (allele A) in our population. The AA genotype has been described in a positive association with obesity and the $A$ allele also with insulin resistance, metabolic conditions often related to high serum levels of adipokine. Conclusions: Our results demonstrate the modifying effect of abdominal obesity on the observed association between a variant in the RETN with asthma. Functional studies are needed to clarify the inflammatory hypothesis of the associations.Thus, we will measure serum resistinandRETN expression in individuals with asthma and to relate it to the observed variant.

Keywords: Asthma. Obesity. Resistin. Genetic.

Support: FAPESB.

\section{ASSOCIATION OF VARIANTS IN GENES OF THE GLUCOCORTICOID PATHWAY WITH LACK OF CONTROL IN PATIENTS WITH SEVERE ASTHMA}

\author{
Maria Borges Rabêlo de Santana ${ }^{1} ;$; Helena Mariana Pitangueira Teixeira ${ }^{1}$; Hátilla dos Santos Silva ${ }^{1}$;Álvaro A. Cruz²; \\ Camila Alexandrina Figueiredo ${ }^{1 ;}$ Ryan dos Santos Costa $^{1}$ \\ ${ }^{1}$ Laboratório de Imunofarmacologia e Biologia Molecular, Instituto de Ciências da Saúde, Universidade Federal \\ da Bahia, Salvador, Bahia, Brasil. 2Programa para o Controle de Asma na Bahia (PRoAR), Universidade Federal da \\ Bahia (UFBA), Bahia-Brasil.
}

Introduction: Asthma is a chronic respiratory disease and can be characterized as a obstructive condition in which the inflammation observed plays an important role in increasing airway hyperresponsiveness. There is a heterogeneity of immunological profiles in asthma and a great heterogeneity in the disease in relation to sub-phenotypes, intensity and severity of symptoms, in addition to the therapeutic response. In this context, glucocorticoids are used to reduce 
inflammation and consequently reduce symptoms and exacerbation. Despite being a widely used therapy, there is variability in the response to this medication and genetic mechanisms may partially explain such variation in the therapeutic response. Objective: To investigate the association of variants in genes whose expression is altered by glucocorticoids with the lack of control in patients with severe asthma. Material and Methods: The study was composed of 363 participants who have severe asthma and are accompanied by the Program for the Control of Asthma and Allergic Rhinitis in Bahia (ProAR), residents of the city of Salvador. Asthma control in these patients was assessed using the ACQ6, which is validated in Brazil. DNA was extracted from peripheral blood and genotyping was performed using the Infinium Multi-Ethnic Global chip. The selected genes showed altered expression after exposure to glucocorticoids in two previous studies. Quality control was applied to the variants considering the frequency of the smallest allele, genotyping rate and Hardy-Weinberg balance.The association analysis was performed in the $R$ software using the GENESIS package. Age, sex and the first main component were included as covariables. Results and Discussion: 368 genes were evaluated, totaling 10772 variants after quality control. Five variants were found in five different genes suggestively associated with lack of control in severe asthma, three positively associated (in the FRMD4B, SEMA3AandFMN1genes) and two negatively associated (in the IL6ST and BCL2 genes). Conclusions: The variants in FRMD4B, SEMA3Aand FMN1 genes are risk factors for the control of severe asthma while variants inIL6ST and $B C L 2$ genes are protective factors. Future studies are needed both to validate the findings here and to elucidate a possible functional impact of these variants.

Keywords: Glucocorticoids, asthma, variants.

Support: CAPES, FAPESB, CNPq.

\title{
ASSOCIATION OF VARIANTS IN THE PPARYGENE WITH OBESITY IN A BRAZILIAN POPULATION
}

\begin{abstract}
Ana Paula C. Meloํㅜ; Helena Mariana Pitangueira Teixeira ${ }^{1}$; Raisa Santos Coelho ${ }^{1 ;}$ Neuza Maria Alcantara-Neves ${ }^{1}$;
\end{abstract} Maurício Lima Barreto ${ }^{2,4}$; Ryan dos Santos Costa;Laise C.Pinto ${ }^{3}$;Camila A. Figueiredo ${ }^{1}$

1. Instituto De Ciências Da Saúde, Universidade Federal Da Bahia, Salvador - Ba - Brasil; 2. Instituto De Saúde Coletiva, Universidade Federal Da Bahia, Salvador - Ba-Brasil; 3. Universidade Federal Da Bahia, Salvador -

Ba-Brasil; 4. Escola De Nutrição, Universidade Federal Da Bahia, Salvador-Ba-Brasil; 4. CIDACS - Centro de Integração de Dados e Conhecimentos para Saúde - FIOCRUZ; Programa de Pós-Graduação em Imunologia PPGIMLaboratório de imunofarmacologia e biologia molecular-Salvador/Bahia/Brazil.

Introduction: Obesity is a chronic disease with an increased risk of comorbidities such as cancer and asthma. Obesity has been considered a low-grade inflammatory disease, directly related to insulin resistance and type 2 diabetes mellitus. Peroxisome proliferator-activated receptor gamma (PPAR $\gamma$ ) is a regulator of lipid and glucose metabolism. Dysregulation of PPARy is linked to the development of obesity, type 2 diabetes, atherosclerosis and other disease conditions. PPARY regulates the expression of numerous genes involved in lipid metabolism, including aP2, acyl-CoA synthetase and lipoprotein lipase (LPL). It also controls the expression of the fatty acid carrier protein 1 (FATP-1) and CD36, both involved in the uptake of lipids by adipocytes. Objective: To evaluate whether there is an association between PPARY gene polymorphisms and obesity in Brazilian children. Methods: The study comprised 1004 children between 4-11 years. Genotyping was done using the Illumina 2.5 Human Omni bead chip. Logistic regression was used to assess the association between IMC and the PPARy gene variations in PLINK 1.07 software. The multivariate analysis was carried out adjusting for sex, age and ancestry markers. Results and Discussion: From 1,010 children included in this study, 15.5\% (156) had overweight. In addition, 59\% of the obese children were male and had an average age of 5 years. There were overall statistically significant differences for age, but not for sex, between cases and controls. Four SNVs inPPARywere associated with obesity, three of themnegatively associated with obesity using anadditive model (rs4135268(G allele, OR: $0.45 \mathrm{Cl} 95 \%$ : 0.22-0.92), rs13083375(T allele, OR: 0.44 Cl 95\%: 0.21-0.94), rs13064760 (T allele, OR: $0.45 \mathrm{Cl} 95 \%$ : 0.21-0.94) and one positively associated with obesity in the XXX model (rs12485478 (G allele, OR: 1.17 Cl 95\%: 1.17-2.97)). Conclusion: The SNVs rs4135268, rs13083375, rs13064760 andrs12485478 inPPARY are associated with obesity in Brazilian Children. Further studies are needed to better understand and elucidate the mechanisms wherebysuchSNVs are involved with obesity in Brazilians.

Keywords: children, obesity, inflammatory gene: Support Fapesb 


\title{
CHARACTERIZATION OF MI-RNAS IN THE PHENOTYPIC DYSREGULATION OF GLIOBLASTOMA AND MICROGLIAL CELLS AND AS TARGETS OF ANTITUMORAL FLAVONOIDS
}

\author{
$\underline{\text { Karina Costa da Silva }}{ }^{1}$, Balbino Lino dos Santos ${ }^{1}$, Dora Brites ${ }^{2}$, Silvia Lima Costa ${ }^{1}$ \\ ${ }^{1}$ Neurochemistry andCellBiologyLaboratory, BiochemistryandBiophysicsdepartment, Federal Universityof Bahia, \\ Bahia, Brazil; ${ }^{2}$ Instituto de Investigação do Medicamento da Faculdade de Farmácia da Universidade de Lisboa, \\ Portugal.
}

Introduction: The glioblastoma (GBM) is the most frequent cerebral tumor with a poor prognostic and short life time. Besides that, it is difficult treatment, which is aggressive and of reduced effectiveness duetochemio- and immunoresistant. Recently, the microRNAs's (post-transcriptional and non-coding agents) have been describe as having important role in the prognosis of GBMs. The flavonoids apigenin and bis-apigenin have been shown to inhibit GBM cell proliferation and invasion, in association withthemodulation of the inflammatory profile of microglia. In this context, knowledge of the effect of these molecules on the modulation of miRNA expression is of great value, as well as understanding the relationship with thereversal of the tumor phenotype and modulation of the of microglia inflammatory phenotype that favours block age of tumor cells proliferation. Objectives: This project aims to characterize the involvement of onco- and inflammo-miRNAs in the phenotypic dysregulation of GBM and microglia cells and as targets for flavonoids with antitumoraction. As specific Objectives we seek to identify the role miR-155/21/-124/146a in the phenotypic dysregulation of human GBM (U87, GL15, U373) and microglia (CHME3) cells isolated and in cocultures, as well as during direct cell-cell communication (glioma/microglia co-cultures) by the analysis of its profile in these cretome. In addition, we aim to test the efficacy of the apigenin and bis-apigenin flavonoids in the modulation of onco-miRNAs, recovery of the "responder" microglial phenotype and in there versal of the astrocytic GBM malignant phenotype. Methods: We Direct and indirect interaction will be adopted in isolated and in GBM/microgliaco-culture models. Immunocytochemistry will be adopted to evaluate proliferation morphology and phenotype. Moreover, cell viability/death will be measured by staining with the stain of Propidiumlodide (necrosis) in association with Annexin-5-FITC (apoptosis). Exosomes will be is olated from the GBM/CHME3 co-culture medium by differential ultracentrifugation to characterize mi-RNA's through the RTqPCRreactionusing primers for the 155/21/-124/146a mi-RNA's. Expectedresults: With the results obtained, it will be possible to characterize the effects of apigenin and bis-apigenin on modulation of onco and inflammo miRNAs expression and the relation between antiglioma and immunomodulatory effects of these flavonoids in view to contribute to future therapeutic strategies.

Support: FAPESB (INT 016/2016 ); CAPES (PGCI Proc. - 88881.117666/2016-01); Nacional Institute for Translational Neuroscience and INCT for Excitotoxicity and Neuroprotection (MCTI/CNPq).

\section{CHARACTERIZATION OF THE GLIAL RESPONSE ASSOCIATED TO NEUROPROTECTION INDUCED BY THE FLAVONOID AGATHISFLAVONE IN VITRO MODELS OF BRAIN INJURY.}

Verônica Moreira de Sousa', Cleonice Creusa dos Santos', Áurea Maria Alves Nunes'1, Juliana Helena Castro Silva', Jorge Mauricio David ${ }^{2}$, Maria de Fátima Dias Costa', Arthur Morgan Butt ${ }^{3}$, Victor Diógenes Amaral', Silva Lima Costa ${ }^{1}$

'Laboratory of Neurochemistry and Cell Biology, Department of Biochemistry and Biophysics, Institute of Health Sciences, Federal University of Bahia, Salvador, Bahia, Brazil. ${ }^{2}$ Department of General and Inorganic Chemistry, Institute of Chemistry, Federal University of Bahia, Brazil. ${ }^{3}$ School of Pharmacy and Biomedical Sciences, University of Portsmouth, United Kingdom.

Introduction: Brain injury is a major cause of death and disability in humans and animals. A cascade of events at the molecular level and biochemical changes begins minutes after the initial injury, such as cellular hyperexcitability, astrogliosis and glial scarring, edema, hypoxia/ischemia, oxidative stress and inflammation, involving immunoprotective glial cells, which in turn can contribute to induce the expansion of the primary lesion. Thus, the development of drugs that can reduce the damage caused by the encephalic injury is extremely important. Previous studies, demonstrated that the flavonoid agathisflavone modulates the astrocytic response (astrogliosis) and the formation of the glial scar, favoring the migration of astrocytes and neurons to the injury site, and stimulating the restoration of the neural network, effects associated with increased expression of the neurotrophic factors NGF 
and GDNF. However, the mechanisms of glial response involved is not yet fully understood. Objectives: The present study aims to characterize the effect of the flavonoid agathisflavone on the activation of astrocytes and microglia in an in vitro model of brain injury. Methods: Brainmixed culture (glia/neurons) will be obtained from Wistar rats (7-9 days old) and maintained in supplemented DMEM/F12. After 3 days in vitro, culture will be maintained in control conditions or pre-treated (1-hourbefore the injury) with agathisflavone $(1 \mu \mathrm{M})$, and then the cultures will be subjected or not to a mechanical injury with the aid of a $200 \mu \mathrm{L}$ sterile polystyrene pipette tip. After 24 hours, cultures will be processed for experimental analysis. Neuronal integrity will be assessed by the Fluoro-Jade-B reagent and by immunocytochemistry (ICQ) for $\beta$-tubulin III. The morphology, glial reactivity and inflammatory profilewill be analyzed by ICQ for the astrocyte markersGFAP, GS, and for the microglia markerslba-1, CD68 and CD206, and by measuring mRNAexpression for of TNF, IL1 $\beta$, IL-6, IL10, TGF $\beta$ and arginaseinflammatory markers by RT-qPCR. Expected results: The clarification of how this compound acts in the integration of neuroimmune signals in conditions of diseases characterized by glial reactivity and neurodegeneration, such as encephalic injury, will contribute to the development of new or combined therapies for this pathology and other related disorders.

Keywords: neuroinflammation, microglia, astrocyte, Agathisflavone, neuroprotection Support: Support: FAPESB (INT 016/2016);CAPES (PGCI Proc. - 88881.117666/2016-01); INCT Nacional Institute for Translational Neuroscience and INCT for Excitotoxicityand Neuroprotection (MCTI/CNPq).

\title{
CHARACTERIZATION OF THE IMMUNOLOGICAL MECHANISMS INDUCED IN VITRO BY THE SM29 ANTIGEN IN MACROPHAGES OF ASTHMATIC INDIVIDUALS
}

\author{
$\underline{\text { Luís Eduardo Ribeiro }}^{1,2}$; Tarciano Nascimento ${ }^{1,2}$; Dário Pascali ${ }^{1,2}$; Gabriela Pimentel Pinheiro ${ }^{6}$ : Diego Mota Lopes ${ }^{1,}$ \\ 2; Jordana Batista ${ }^{1,2}$; Tarcísio Almeida²,2; Sérgio C. Oliveira³; Edgar M. Carvalho²,4 Álvaro Augusto Cruz ; Luciana S. \\ Cardoso ${ }^{1,2,5}$ \\ ${ }^{1}$ Programa de Pós-graduação em Imunologia, PPGIm, ICS/UFBA; 2 Serviço de Imunologia, Hospital Universitário \\ Professor Edgard Santos - HUPES/UFBA; ${ }^{3}$ Departamento de Bioquímica e Imunologia, Instituto de Ciências \\ Biológica, UFMG-MG, Brazil; ${ }^{4}$ Centro de Pesquisas Gonçalo Moniz, FIOCRUZ-Ba, Brazil; ${ }^{5}$ Departamento de Análises \\ clínicas e toxicológicas, Faculdade de Farmácia, UFBA. ${ }^{6}$ Programa para o Controle da Asma na Bahia - ProAR/
} UFBA.

Introduction: Chronic respiratory diseases are some of the leading causes of illness and death in the world, such as asthma that affects more than $\mathbf{3 5 0}$ million people worldwide. Evidence has been accumulating that chronic helminth infection, particularly Schistosoma spp. or parasite products, is capable of modulating the inflammatory response. Objective: To characterize the immunological mechanisms induced by recombinant Schistosoma mansoni Sm29 antigen ( $r S m 29$ )in vitro in $\mathrm{M} 1$ and $\mathrm{M} 2 \mathrm{a}$ and $\mathrm{M} 2 \mathrm{c}$ macrophages of individuals with asthma. Materials and Methods: Macrophages of individuals with asthma were differentiated in M1 and M2a by the addition of IFN+LPS and IL4+IL13, respectively. The cultures were then stimulated with Sm29. Since Sm29 is able to induce high amounts of IL-10 in previous studies, we tested if this antigen is able to differentiate macrophages into M2c population.The frequency of macrophages producing TNF and IL-1 $\beta$ was evaluated by flow cytometry analyses. The levels of IL-10 in cultures supernatants stimulated by Sm29 antigen were evaluated by sandwich ELISA. Results and Discussion: The presence of $\mathrm{rSm} 29$ reduces the frequency of $\mathrm{M} 1$ and $\mathrm{M} 2 \mathrm{a}$ macrophages in the culture upon differentiation. And preliminary results demonstrate that the reduction in frequency of the $\mathrm{M} 1$ and $\mathrm{M} 2 \mathrm{a}$ populations may be related to the increase in M2c population. There is a reduction in the production of proinflammatory cytokines (TNF and IL1 $\beta$ ) by $\mathrm{M} 1$ macrophages stimulated with $\mathrm{rSm} 29$. In macrophage cultures of asthmatic patients stimulated with $\mathrm{rSm} 29$ in the presence of IFN- $\gamma$ and in the presence of IL-4 and IL-13, an increase in IL-10 production was observed when compared to cultures without stimulation in the same differentiation conditions. In cultures stimulated with rSm29, the frequency of $\mathrm{M} 2 \mathrm{c}$ correlated positively with the concentration of IL-10 measured in the supernatant of these cultures. Conclusion: Preliminary results demonstrate the ability of $r S m 29$ antigen to regulate the $M 1$ and $M 2 a$ macrophages that is involved in inflammatory response of asthmatic individuals, as results of the up-regulation of IL-10 production. The rSm29 antigen appears to be a feasible candidate for developing a therapeutic strategy for the treatment of this disease.

Keywords: asthma, Sm29, macrophages. Support: FAPESB and CNPq. 


\title{
CHARACTERIZATION OF THE NEUROPROTECTIVE AND ANTI-NEUROINFLAMMATORY EFFECTS OF FLAVONOID AGATHISFLAVONE (APIGENIN AND BIS-APIGENIN): ROLE OF TRYPTOPHAN CATABOLISM
}

\author{
Deivison Silva Argolo ${ }^{1}$, Gizelle Alves Pina', Silvia Lima Costa ${ }^{1}$, Maria de Fatima Dias Costa ${ }^{1}$ \\ ${ }^{1}$ Neurochemistry and cell biology laboratory. Federal University of Bahia,
}

\begin{abstract}
Introduction: The nervous system is a complex tissue characterized by its cellularity with specific and distinct functions in relation to other tissues in the body. Astrocytes and microglia make up glia, cells with characteristics responsible for maintaining tissue homeostasis and favoring a microenvironment for the better functioning of neurons, which in turn are responsible for synaptic communication. Under conditions of stress and inflammation, the cells of the central nervous system (CNS) position themselves to trigger an effective immune response, which may involve biochemical mechanisms such as the release of nitric oxide, stimulation of apoptotic pathways and activation of catabolic pathways, example of the tryptophan pathway. Tryptophan catabolism produces cinurenines that regulate homeostasis within nervous tissue. In vitro models have been used to verify the role of this pathway, and it has recently been shown that in a parasitic infection of neuron / glia co-cultures, the inflammatory stimulus activated the production of quinolinic acid, a catabolite that has an affinity for NMDA neuronal receptors. In turn, flavonoid phytochemicals, have shown neurogenic and antineuroinflammatory actions on nervous tissue, by modulating glial cells. Objective: to correlate the antineuroinflammatory action of flavonoid agathisflavone with tryptophan catabolism in nervous system cells subjected to inflammatory stimuli. Material and Methods: Primary cultures of rat cerebral cortex (P 0-2) will be subjected to treatment with INF1 $\beta$ and LPS subsequently treated with agathisflavone flavonoids (apigenin and bis-apigenin) followed by removal of the culture medium to be filtered (Millipore $0.22 \mu \mathrm{m}$ ) and used to evaluate tryptophan catabolites by high performance liquid chromatography (HPLC). The morphology and reactivity of astrocytes, microglia and neurons will be investigated respectively by immunocytochemistry (ICQ) using glial fibrillar acid protein (GFAP), the ionized calcium binding adapter molecule 1 (Iba-1) and $\beta$ tubulin. To evaluate the expression of enzymes in this pathway, qPCR will be used. Perspective: It is hoped that the inflammatory process can be associated with the stimulation of the production of quinolinic acid and the anti-inflammatory action of flavonoid agathisflavone, can be related to the release of cinurenic acid, providing neuronal preservation and bringing therapeutic potential for neuropsychiatric diseases, associated with neurodegeneration such as Parkinson's disease, Alzheimer's, among others. Keywords: neuroinflammation, neuron, microglia, astrocyte, Agathisflavone, neuroprotection.
\end{abstract}

Support: FAPESB.

\section{CIRCUMVENTING ANTIMONIAL THERAPEUTIC FAILURE IN LEISHMANIA BRAZILIENSISINFECTIONS BY TARGETING ABC TRANSPORTERS}

\author{
Marina Borges Rabelo de Santana, Edgar Marcelino de Carvalho Filho, Lucas Pedreira de Carvalho
}

Laboratório de Pesquisas Clínicas, IGM, Fiocruz, Bahia, Brasil.

Introduction: Cutaneous leishmaniasis (CL), caused by Leishmaniabraziliensis, is a disease with a wide spectrum of clinical presentations, characterized by the presence of one or more ulcers with high edges. The most important limitations of leishmanicidal drugs are the high rate of treatment failure, the emergence of drug-resistant parasites and the abandonment of treatment by patients.

The host genes associated with drug resistance, such as those of the $A B C$ transporter family (ABCB1 and $A B C C 1$ ), responsible for the efflux of drugs, are more expressed in lesions of patients with $\mathrm{CL}$ when compared to the skin of healthy individuals. The higher expression of these proteins may therefore be associated with the therapeutic failure of the leishmanicidal compounds. Consequently, the use of drugs that inhibit ABC transporters (Verapamil, Probenecid or Lovastatin), could prevent the efflux of medications such as pentavalent antimonial (SbV), the medication preferably used in Brazil to treat $\mathrm{CL}$, thus leading to its accumulation in the host cell and increasing its parasiticidal activity. Objectives: The objective of this project is to compare the activity of $A B C$ transporters in individuals with $\mathrm{CL}$ or early cutaneous Leishmaniasis (ECL) who have failed SbV therapy with the activity of $A B C$ in 
individuals who have healed after treatment. In addition, we will test whether inhibitors of $A B C$ transporters increase the leishmanicidal efficacy of the pentavalent antimonial as well as its influence on cytokine production.

Methods: We are cultivating macrophages infected with Leishmaniabrasiliensis strains obtained from aspirates from lesions of patients with CL or ELC who have healed and have failed treatment with SbVthrough the use of a technique of flow citometry to calculate the parasiticidal activity of drugs and by counting intracellular amastigotes in cells. In addition, we will verify the activity of $A B C$ in uninfected and infected macrophages in the presence of $A B C$ inhibitors in conjunction with SbV.

Conclusions: Through these results, it is possible to think about the association of SbV with the inhibitor that presents better results, thus reducing the costs with new therapy courses for individuals who fail and investing in promoting the population's awareness about the highest cure rates and the treatment effectiveness even in the most recent phase.

Keywords: Leishmania braziliensis, ABC transporters, cutaneous leishmaniasis.

Support: Capes, IGM-Fiocruz Bahia

\title{
COMBINED ADJUVANT THERAPY INVOLVING BCG AND IMIQUIMOD INCREASES THE SURVIVAL OF C57BL/6 MICE DURING EXPERIMENTAL MELANOMA
}

\author{
$\underline{\text { Maiara Bonfim }}{ }^{1-2}$, Amanda Silva ${ }^{1-2}$, Davi Salles ${ }^{1}$, Rosa Pinho ${ }^{3}$, Jose Mengel ${ }^{3-4}$, Fabiola Cardillo . $^{1}$ \\ ${ }^{1}$ Gonçalo Moniz ResearchInstitute. Oswaldo Cruz Foundation, LAPEM, Salvador-Ba, Brazil. ${ }^{2}$ Federal Universityof \\ Bahia (UFBA), PPGIm, Salvador-Ba, Brazil. ${ }^{3}$ Oswaldo Cruz Foundation, Oswaldo Cruz Institute, Fiocruz, Rio de \\ Janeiro, Brazil. ${ }^{4}$ Faculty of Medicine of Petrópolis, FMP-FASE, Petrópolis, Rio de Janeiro, Brazil.
}

Introduction: The study of adjuvant therapies has become increasingly relevant in efforts to treat cutaneous tumors like melanoma effectively. Imiquimod (IMIQ) induces an efficient antitumor immune response by activating the Tolllike receptor seven pathway (TLR7). Another immunotherapy is to use Bacillus Calmette-Guérin (BCG) for an effective antitumor response. The present study aims to use new tools to evaluate the combined adjuvant effect of BCG and IMIQ on antitumor activity. Methods: C57BI6 mice were inoculated with B16F0 tumor cells subcutaneously at $5 \times 104$ cells $/ 20 \mu \mathrm{L}$. Subsequently, mice were treated with $10 \mu \mathrm{L}$ of IMIQ at $50 \mathrm{mg} / \mathrm{mL}$ twice daily. Mice received BCG in situ at the concentration of $1 \times 107 / 60 \mu \mathrm{L}$, ten days after tumor cell inoculation. Tumor growth and mortality were monitored, and splenic cells from experimental groups were evaluated by flow cytometry on the 18th after B16F0 cell-grafting. Experimental groups used: 1- Naïve (control) mice. 2- Mice that received BCG and IMIQ (IMIQ+BCG). 3- Mice injected with tumor cells (B16F0). 4- Mice challenged with BCG and treated with IMIQ (B16F0+IMIQ+BCG). Results: The combined treatment protocol B16F0+IMIQ+BCG resulted in significantly increased survival compared to B16F0 mice ( $p=0.0001$; Log-rank test). In addition, significantly reduced tumor growth was seen in B16F0+IMIQ+BCG compared to B16F0 on days 10 ( $p=0.0115$; Mann-Whitney), 12 ( $p=0.0008$; Mann-Whitney), 15 ( $p=0.0434$ MannWhitney), 18 ( $p=0.0219$; Mann-Whitney) and 20 ( $p=0.0406$; Mann-Whitney). B16F0+IMIQ+BCG and IMIQ + BCG (without tumor cells) groups have presented increased CD4+ T cells, NK, and NKT splenic cell-numbers, compared to the B16F0 group (Mann-Whitney test $\mathrm{p}=0.0286$ ). For the CD8+ splenic T cell-number, the B16F0, B16F0+IMIQ+BCG, and IMIQ+BCG groups are different when compared to each other (Kruskal Wallis, $p=0.0177$ ). There was a trend in splenic cells to sustain the number of regulatory T cells (Treg) and myeloid-derived suppressor cells (MDSC) in the studied groups. Conclusions: The combined adjuvant treatment of IMIQ+BCG increased the longevity and tumor restrainment in an experimental murine model of melanoma. Increased number of CD4+ T cells, NK and NKT cells, and the maintenance of Treg and MDSC splenic cells are related to the immune response against melanoma in mice treated with BCG and IMIQ.

Keywords: Experimental Melanoma, Imiquimod, BCG, NK Cells, NKT Cells

Support: by PAPES-CNPq (proc.407752/2012-9). MB is CAPES; AS and DS are FAPESB fellowships. 


\title{
CYTOKINE PROFILE INDUCED BY DERMATOPHAGOIDES PTERONYSSINUS IN WHOLE BLOOD CELL CULTURE FROMTEENAGERS IN SCAALA 2013
}

\author{
Flávia de Araújo Sena1, Emília Maria Medeiros de Andrade Belitardo1, Alana Alcântara Galvão1, Laure Laine dos \\ Santos de Jesus1, Daniel dos Santos Rocha1, Anaque de Oliveira Pires2, Gerson de Almeida Queiroz2, Álvaro \\ Augusto Souza da Cruz Filho3, Maurício Lima Barreto4, 5, Camila Alexandrina Viana de Figueiredo2, Neuza Maria \\ Alcântara Neves1 \\ ${ }^{1}$ Departamento de Biointeração, Laboratório de Alergia e Acarologia, Universidade Federal da Bahia, Bahia, Brasil. \\ ${ }^{2}$ Departamento de Biointeração, Laboratório de Imunofarmacologia e Biologia Molecular, Universidade Federal da \\ Bahia, Bahia, Brasil. ${ }^{3}$ ProAR, Faculdade de Medicina, Universidade Federal da Bahia (UFBA), Salvador, Bahia, Brasil. \\ ${ }^{4}$ Instituto de Saúde Coletiva, Universidade Federal da Bahia (UFBA), Salvador, Bahia, Brasil. ${ }^{5}$ Centro de Integração \\ de dados e Conhecimentos para Saúde (CIDACS), Fiocruz, Bahia, Brasil).
}

Introduction: Dust mites are important cause of allergy in the World, being one of the main source of sensitization to IgE and a risk factor to allergic diseases. Among them, Dermatophagoidespteronyssinus is the most important source of inhaled allergens worldwide. Objectives: This study aim to investigate thecytokine profile induced by $D$. pteronyssinus extract $(D p E)$ in whole blood cells'culture supernatants from teenagers participating inSCAALA Program 2013 (Social Changes Asthma and Allergy in Latin America) according to asthma and atopy status. Methods: Asthma outcome was evaluated using an ISAAC phase II questionnaire translated to Portuguese. Serum sampling was used for detection of allergen-specificlgE by ImunoCAP (Phadia/ThermoFischer, Massachusetts, USA). As ample of blood collected for each partipants was used for 120 hours whole blood cells culture, at $5 \% \mathrm{CO}_{2}$ stimulated with $D p$ Eextract. IFN- $\gamma$, TNF $\alpha$, IL-5, IL-13, IL-17 and IL-10 cytokines were measured in the cells supernatants by Luminex (The MILLIPLEX ${ }^{\circledR}$ Human Cytokine/Chemokine, Merck KGaA; Darmstadt, Germany) in 440 of985 blood donator. Statistical analyses weredone using SPSS 22.1. Non-parametric tests (Kruskal Wallis and Mann-Whitney) were used. Results/Discussion: From the 440 participants whose cytokine dosageswereobtained, 205 were atopics, 21 asthmatics, 12 atopics asthmatics. Atopic patients had the highest production of IL-5 (atopic median: 1.34, non-atopic: $0.62 P=0.0001$ ) and IL-13 (atopic median: 3.76, non-atopic: $2.59 P=0.026$ ). The increases of slgE also increased the median of these cytokines. Both cytokines, IL-5 and IL-13, are Th2 type and D. pteronyssinusallergens are involved in Th2 polarization response resulting in atopy and allergy development. No statistically significant difference in cytokine production was observed between the asthmatic and non-asthmatic groups. Conclusions: Higher levels of Th2 cytokines were observed inDpE stimulation of total blood cells in atopic teenagers; however, no difference in cytokine production was observed in asthmatics compared to non-asthmatic population. This may be due to the reduced number of asthmatics in the present study. New analyses will be made in order to verify the other stimuli used in cell cultures and to use a statistical approach that best suits the data analyzed.

Keywords: Dust mite, Atopy, Dermatophagoidespteronyssinus, Asthma; slgE;

Support: FAPESB, CNPq

\section{DYNAMICS OF SEROCONVERSION AND IMMUNE CELL RESPONSE AS MARKERS FOR DIAGNOSIS AND PREDICTORS OF PROGNOSIS IN SARS-COV 2 INFECTION}

\author{
Isa Rita Brito de Morais, Alex José Leite Torres.
}

Laboratório de Imunologia e Biologia Molecular - ICS/UFBA, Salvador, Bahia, Brasil.

Introduction: SARS (severe acute respiratory syndrome) is an infectious disease that represented a major threat to international public health in 2003, affecting 12 countries, with the coronavirus (SARS-CoV) being identified as its etiological agent, reappearing in 2012 in the Middle East. In December 2019, the city of Wuhan, capital of Hubei province in China, became the center of a new outbreak of pneumonia attributed, this time, to a new strain of coronavirus (SARS-CoV-2), transmitted by airways, now called, by the World Health Organization (WHO), as Coronavirus 2019 (COVID-19), quickly reaching pandemic status. The characteristics of seroconversion in SARS-CoV-2 are not well defined, as they demonstrate a significantly idiosyncratic relationship with the patient in view of his 
immune response, suggesting an important influence linked to interfering factors in the protection of viral infections between different expressions of ancestry. Mechanisms of action of cells and the dynamics of their expressions during immune activation have demonstrated, in several studies since the isolation of coronaviruses, important actions as diagnostic markers and, mainly, prognoses that, if identified, can contribute to the evolutionary prevention of the disease. Objective: To characterize specific markers of the humoral and cellular immune response for SARSCov2, which determine indexes for the evaluation of the host's diagnosis and prognosis. Materials and Methods: 100 patients tested positive for SARS-Cov2 will participate in the study, being divided into four groups according to mild, moderate and severe clinical conditions, in addition to a control group of seronegative individuals. Patients will come from diagnostic testing centers in the cities of Salvador and Feira de Santana, Bahia. After signing the Free and Informed Consent Form, samples of nasal / oropharyngeal secretion and $4.5 \mathrm{ml}$ of blood will be collected for the characterization of the cellular immune response, evaluation of seroconversion and autoantibodies, in addition to the identification and genotyping of ancestry markers. This project will be submitted to the Research Ethics Committee of the "Instituto de Ciências da Saúde da Universidade Federal da Bahia", according to Resolution 466/2012 of the National Health Council, and the volunteers will be informed verbally and in a written document.

Keywords: SARS vírus, Coronavírus infections, seroconversion.

Support: MCTIC/CNPq/FNDCT/MS/SCTIE/Decit № 07/20 - registro401727/2020-3.

\section{EFFECT OF SCHISTOSOMA MANSONI SM29 ANTIGEN ON MACROPHAGE INFECTIVITY BY LEISHMANIA BRASILIENSIS}

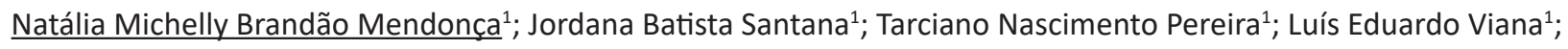
Nestor Guerrero Gutiérrez ${ }^{1,2}$; Luciana Santos Cardoso ${ }^{1,2,3}$.

${ }^{1}$ Programa de Pós-Graduação em Imunologia. Universidade Federal da Bahia-UFBA. Salvador/Bahia. Brasil. ${ }^{2}$ Serviço de Imunologia. Hospital Universitário Professor Edgar Santos (HUPES), UFBA Salvador/Bahia. Brasil. ${ }^{3}$ Departamento de Análises Clínicas e Toxicológicas, Faculdade de Farmácia, UFBA. Salvador/Bahia. Brasil.

Introduction: Leishmaniasis is an endemic disease in South and Central America, Africa and Asia, caused by a variety of species of parasites of the genus Leishmania. Currently, 88 countries with tropical and sub-tropical climate are affected by leishmaniasis. The immune response to this parasite is of the Th1 type, which is important for the activation of macrophages and elimination of Leishmania, but it is also the main responsible for the pathogenesis of cutaneous disease, mainly related to tissue damage. On the other hand, antigens derived from parasites with a modulatory potential of the immune response, such as the Sm29 antigen of Schsitosomamansoni, have been evaluated for the potential to regulate the exacerbation of the immune response in immune-mediated diseases. Objective: To evaluate the effect of the S. mansoni Sm29 antigen on the infectivity of macrophages derived from monocytes in vitro infected with L. braziliensis. Methodology: The monocytes will be cultured in the presence of M-CSF for differentiation in to macrophages and then infected with L. braziliensis promastigotes and stimulated with the Sm29 antigen. The number of infected macrophages, the frequency of amastigotes per macrophage, as well as the expression of the enzymes iNOS and arginase will be evaluated by RT-PCR. The levels of cytokines TNF, IL-12 and IL-10 in the culture supernatant will also be analyzed. The results of this work will assist in understanding the mechanisms involved in the regulation of the immune response induced by the Sm29 antigen in leishmaniasis, as well as assessing whether this antigen influenced the infectivity of the parasite and the macrophages ability to kill leishmania.

Keywords: Leishmaniasis. Sm29. Macrophages.

Support: CAPES / CNPq / INCT. 


\title{
EFFECTS OF ASC CONDITIONED MEDIA IN TISSUE REGENERATION
}

\author{
Brysa Mariana Dias Silveira ${ }^{1,2}$; Songeli Menezes Freire ${ }^{1,2}$; Vitor Antonio Fortuna ${ }^{1,2}$ \\ ${ }^{1}$ Programa de Pós-Graduação em Imunologia, Instituto de Ciências da Saúde (ICS), Universidade Federal da Bahia \\ (UFBA), Salvador, Bahia, Brasil; 'Laboratório de Imunologia, Departamento de Biofunção, ICS, UFBA, Salvador, \\ Bahia, Brasil.
}

\begin{abstract}
Introduction: Chronic leg ulcers (CLU) are very common with an estimated prevalence of 0.6 to $5 \%$ among patients over 65 years of age. CLUs are recalcitrant, cause a low quality of life and often lead to lower extremity amputation, representing both a significant health risk and a large economic burden. Adipose derived-mesenchymal stromal cells (ASC) are a potential alternative for treatment of CLUs. These cells secrete cytokines, growth factors, and bioactive molecules responsible for the effects of skin repair and regeneration. A promising strategy to enhance the secretory profile of ASC is the optimization of its angiogenic and regenerative potential through external stimuli. Objectives: the present study evaluated the effects of normoxia and hypoxia preconditioning on the ASC secretome and analyzed the expression of soluble mediators involved in the tissue repair process. Materials and Methods: ASC were isolated from liposuction samples, subjected to culture in normoxic and hypoxic conditions for 48 hours and evaluated for their angiogenic and regenerative potential. Results and Discussion: The ASC secretome preconditioned in normoxia and hypoxia showed in its composition the markers of cell regeneration and other growth factors involved in angiogenesis and tissue repair. In vitro analysis demonstrated that both conditioned media (CM) exerted antiapoptotic, pro-migratory and angiogenic effects in HUVECs, with better pro-angiogenic performance in cells treated with $\mathrm{CM}$ in normoxia. Analysis in a murine model of wound healing showed improvement in the closure of wounds treated with the conditioned means in normoxia and hypoxia. Conclusion: Both pre-conditioning regimes in normoxia and hypoxia induced the regenerative capacity in the analyzed ASCs. Considering that normoxia pre-conditioning presented better performance and is more practical to obtain, hypoxia pre-conditioning is not necessary.
\end{abstract}

Support: FAPESB, CNPq and PIBIC-UFBA.

Keywords: ASC, chronic ulcers, cell therapy.

\section{EFFECTS OF FLAVONOID RUTIN ON GASTROINTESTINAL FUNCTION AND INTEGRITYIN AN EXPERIMENTAL MODEL OF PARKINSON'S DISEASE}

Livia Bacelar de Jesus, Annyta Fernandes Frota, Fillipe Mendes Araújo; Rafael Leonne Cruz de Jesus, Victor Diogenes Amaral, Darizy Flavia Silva, Marcelo Biondaro Goes, Gyselle Chrystina Baccan, Silvia Lima Costa.

Laboratório de neuroquímica e Biologia Celular - LabNq, Instituto de Ciências da Saúde, Universidade Federal da Bahia, Bahia, Brasil.

Introduction: Parkinson's disease (PD) is considered the second most prevalent neurodegenerative disease in the world. Studies suggest that the enteric nervous system (ENS) may also be involved in the neurodegenerative process underlying PD. The ENS is responsible for controlling intestinal motility and secretion, the involvement of ENS has been shown to be important in the pathophysiology of PD. Another interesting fact is that natural substances, like the flavonoids, can lower the risk for the development of PD. Objective: To evaluate the effect of flavonoid rutin on gastrointestinal function and structure of rats in a PD model. Material and Methods: Male Wistar rats weighing 250-300g were anesthetized and submitted to unilateral nigrostriatal injection of 6OHDA $(21 \mu \mathrm{g})$ and submitted to oral treatment (gavage) with rutin $(10 \mathrm{mg} / \mathrm{Kg}$ ) for 14 days. To confirm damage rats were submitted the rotation test induced by apomorphine $(3 \mathrm{mg} / \mathrm{kg}$, i.p.). The gastrointestinal transit was evaluated before euthanasia by gavage of $0.5 \mathrm{~mL} 6 \%$ Carmine red. The fecal pellets were collected and monitored for $12 \mathrm{~h}$. On the 15th day the rats were anaesthetized and lleum segments were collected and submitted to a histopathological protocol and stained with hematoxylin/eosin. For tissue contraction assays segmentsof ileum were placed in organ baths containing Krebs solution and maintained at $37^{\circ} \mathrm{C}$ and bubbled with 95\% 02/5\% CO2. Carbacol and nitric oxide donor was used to assess tissue responsiveness $\left(10^{-10}-10^{-4} \mathrm{M}\right)$, in addition to $\mathrm{KCl} 80 \mathrm{mM}$. Results and Discussion: The rats in the

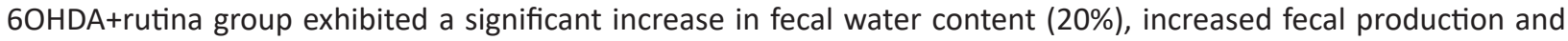
improvement in gastrointestinal transit time of approximately 1 hour when compared to the 6OHDA group. It was 
observed that apparently the treatment with rutin caused an increase in the reactivity of the ileal smooth muscle to muscarinic activation, suggestingreductionin relaxation mediated by nitric oxide signaling pathway.Moreover, histopathological analysis showed an increase in the cell body of paneth cells in the ileum segments of animals in the 6OHDA+rutinademonstrating a greater participation of innate immunity. Conclusion: The results showed that treated with flavonoiderutin appear to improve gastric motility and increase contractility of the ileal segment in parkinsonian rats. Expansion of the study group is necessary to confirm these findings. Future perspectives include analyzes of fecal microbiota and immunohistochemistry for enteric glial cells.

Keywords: Enteric nervous system, Parkinson's disease, Rutin. Support: FAPESB

\title{
AGING AND CHRONIC OBSTRUCTIVE PULMONARY DISEASE: THE ROLE OF THE ENDOCRINE-IMMUNE CROSSTALK
}

\author{
Fabíola Ramos Jesus ${ }^{1}$, Fabine Correia Passos ${ }^{1}$, Margarida Célia Neves², Antônio Carlos Lemos², \\ Gyselle Chrystina Baccan ${ }^{1}$
}

${ }^{1}$ Laboratório de Neuroendocrinoimunologia, Instituto de Ciências da Saúde, Universidade Federal da Bahia, Bahia, Brasil; ${ }^{2}$-erviço de Pneumologia, Ambulatório Magalhães Neto do Complexo HUPES, Bahia, Brasil.

Introduction: Chronic Obstructive Pulmonary Disease (COPD) is a respiratory disease with airflow limitation, chronic inflammation, and the presence of emphysema in the lungs, caused by the inhalation of noxious particles or gases. Agehas been recognized as a risk factor for developing of the disease and studies have shown that COPD patients exhibit an acceleration of the aging process when compared with individuals without COPD. Old age COPD patients could have an additional increase in the production of inflammatory cytokines in pulmonary and plasma level.During aging, there is also important changes in the endocrine system with decrease of in the secretion of dehydroepiandrosterone sulfate (DHEAS) hormone and growth hormone (GH). In previous studies we have shown that the endocrine-immune crosstalk could be explain the sex differences found in COPD patients, which is other risk factor for COPD. Objectives: we propose to investigate the associations between endocrine and immune senescence in COPD patients and the relevance of this crosstalk for COPD. Material and Methods: Individuals with COPD and without COPD (controls), aged between 50 and 80 years, will be recruited in the COPD at the Pneumology Service of the Edgard Santos University Hospital-Federal University of Bahia, and from a public school that offered an adult education program, respectively. Both groups will be divided according to age, considering the adult group composed of individuals aged between 50 to 64 years old and elderly group, aged 65 to 80 years old.After medical evaluation and inclusion in the study, tests will be carried out to assess COPD and determine the severity of the disease, nutritional assessment, blood collection for laboratory tests, application of questionnaires. The DHEA and $\mathrm{GH}$ hormones will be quantified using the chemiluminescence technique and the cytokines will be evaluated in the serum and quantified by the flow cytometry technique.

Keywords: COPD, immunosenescence, hormones

Support: FAPESB

\section{EVALUATION OF ANTIOXIDANT MECHANISMS OF THE FLAVONOID AGATHISFLAVONE AGAINST NEUROINFLAMATORY DAMAGE}

\author{
Janaina Ribeiro Pereira Soares ${ }^{1}$; Silvia Lima Costa'; Juciele Valéria Ribeiro de Oliveira ${ }^{1}$ \\ ${ }^{1}$ Laboratory of Neurochemistry and Cellular Biology, Department of Biophysics and Biochemistry, Institute of Health \\ Sciences, Federal University of Bahia, Salvador-Bahia 40.110-100, Brazil
}

Introduction: Oxidative stress and neuroinflammation are critical features involved in the pathophysiology of neurodegenerative diseases (NDD). Glial cells play a fundamental role in the control of neuroinflammation, modulation of homeostasis and in neuroprotective and neurotoxic mechanisms, which result in loss of structure and neuronal degeneration. In this context, there is a need for effective and complementary therapies to treat and / or mitigate the 
progression of NDD. Polyphenolic compounds like flavonoids are promising candidates as adjuvants for NDD therapydue to theirwell described antioxidant and anti-inflammatory activities. The biflavonoid agathisflavone, derived from the Brazilian plant Poincianella pyramidalis, demonstrated significant neuroprotective and antineuroinflammatory activities in vitro, with potential inactingas modulator of antioxidant pathways in neuroinflammatory conditions. Objectives: This project aims to evaluate in vitro the antioxidant mechanisms of action of agathisflavone, associated with the control of the glial inflammatory response and neuroprotection. As specific Objectives, we seek to analyze in cultures of dissociated cerebellar subject to inflammatory damage, to identify the enzymatic pathways modulated by the agathisflavone, and relation with astrocyte and microglia inflammatory profile.Methods: Cerebellar primary cultures will be obtained from 8 days old Wistar rats. Three days cultures will be treated or not withagathisflavone (1-10 $\mu \mathrm{M})$ and, one hour later, submitted or not to inflammatory damage with LPS $(1 \mu \mathrm{g} / \mathrm{mL})$ or IL-1 $13(10 \mathrm{ng} / \mathrm{mL})$. Twenty-four hours later, different approaches will be adopted for assessing neurons integrity, glia phenotype, free radical levels, andantioxidantsystemsactivity. The integrity of neurons will be analyzed by immunocytochemistry (ICC)for specific structural markers ( $\beta$-Tub III), and astrocyte and microglia reactivity by ICC for structural markers (GFAP and Iba-1, respectively) and analyzing the expression of growth factor and inflammatory cytokines by RTqPCR.SOD, CAT, GST and GST enzymatic activities, the levels of reactive oxygen species (iNOS and H2O2/peroxidase), redox reactions (FRAP) and free radical capture (FRAP, and DPPH) will be determined by colorimetric assays and Western blot. Expected results: With the results obtained, we seek to characterize the antioxidant mechanisms of the flavonoid agathisflavone against neuroinflammatory damage, contributing to studies that help the development of new treatments for NDD.

Keywords: agathisflavone; antioxidant, neuroinflammation.

Support: FAPESB (APP0107/2016; INT 016/2016); CAPES (PGCI Proc. - 88881.117666/2016-01); Nacional Institute for Translational Neuroscience and INCT for Excitotoxicity and Neuroprotection (MCTI/CNPq).

\title{
EVALUATION OF IMMUNOMODULATORY EFFECTS OF SELENIUM DIOXIDE IN MICROGLIAL RAT CELL CULTURES INFECTED WITH NEOSPORA CANINUM
}

\author{
Brenda Valerio Souza ${ }^{12}$, Ana Elisa Del'Arco Vinhas Costa ${ }^{12}$, Maria de Fátima Dias Costa ${ }^{2}$ Silvia Lima Costa ${ }^{2}$, Alexandre \\ Moraes Pinheiro ${ }^{1}$ \\ ${ }^{1}$ Laboratory of Biochemistry and Veterinary Immunology, Department of Environmental, Agrarian and Biological \\ Sciences, Federal University of Recôncavo da Bahia, Cruz das Almas, Bahia, Brazil. 'Laboratory of Neurochemistry \\ and Cellular Biology, Department of Biochemistry and Biophysics, Institute of Health Sciences, Federal University of \\ Bahia, Salvador, Bahia, Brazil.
}

Introduction: Neospora caninum is an intracellular obligatory protozoan capable of infecting several species of animals. This protozoan has a tropism for the cells of the Central Nervous System (CNS), which can cause degeneration of neurons, astrocytes and microglia. Therefore, elements that can contribute to the neuroprotection of glial cells are sought, reducing deleterious effects caused by the parasite on the host. Selenium dioxide $\left(\mathrm{SeO}^{2}\right)$, derived from Selenium (Se), has immunostimulating, antioxidant and anti-inflammatory properties, and can be supplemented to increase the immune response against damage. Objectives: Evaluate the immunomodulatory effects of $\mathrm{SeO}^{2}$ in microglial rat cell culture infected with $\mathrm{N}$. caninum. Methods: Microglia primary cell culture of the cortex of newborn Wistar rats (0-2 days) will be cultivated. Concomitant to this, tachyzoites of the NcBahia strain will be grown in Vero cells supplemented with RPMI 1640 medium. Microglial cells will be treated with $\mathrm{SeO}^{2}$ at a concentration of $0,4 \mu \mathrm{M}$ and incubated for 24 hours. After that, the microglial cell culture will be infected with $N$. caninum tachyzoites in a 1: 1 proportion of cell/ parasite remaining in the culture for 72 hours. The evaluation of cell viability and toxicity will be provided by the MTT method and dosage of the enzyme Beta-glucuronidase, respectively. Nitric oxide levels will be measured using the Griess method. Glutathione peroxidase (GPX), an important antioxidant enzyme, will be measured before and after modulation with $\mathrm{SeO}^{2}$ in microglial cultures infected with the parasite. As microglial morphological changes, they will be evaluated by immunocytochemistry through the labeling of Iba-1 (ionized calcium-binding adapter molecule-1) and BrdU (bromodeoxyuridine), markers of microglial activation and microglial proliferation, respectively. The quantification of these markers will be assessed by Immunoblotting. Parasitic quantification will be specified by counting tachyzoites, before and after modulation by $\mathrm{SeO}^{2}$, and dosing of pro-inflammatory cytokines by the ELISA method 
(Enzyme-Linked Immunosorbent Assay). Expected Results: It is expected that modulation by SeO ${ }^{2}$ will contribute to the neuroprotection of microglia in the infection by $N$. caninum.

Keywords: Neosporosis; microglial activation; antioxidant system; selenium dioxide.

Support: CAPES

\title{
EVALUATION OF MAPKP38, JNK AND ERK1 / 2 SIGNALING PATHWAYS IN CHRONIC PERIODONTITIS
}

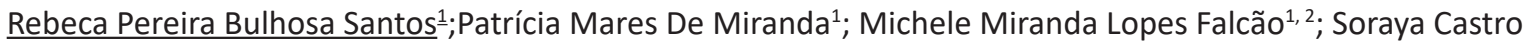 \\ Trindade $\mathrm{e}^{1,2}$
}

${ }^{1}$ Postgraduate Program in Immunology, laboratory of immunology and molecular biology. Federal University of Bahia - UFBA. Salvador/Bahia. Brazilç²Program of Biotechnology, health Department. State University of Feira of Santana - UEFS. Feira of Santana/Bahia. Brazil.

\begin{abstract}
Introduction: Periodontitis is a multifactorial immuno-inflammatory disease whose primary etiological is related to a dysbiotic biofilm on the dental surface. Porphyromonasgingivalis is a Key pathogen in the dysbiosis, having a central rolein the disease progression due to a several of virulence factors, such as $\mathrm{HmuY}$ and $\mathrm{K}$ gingipains, which can elicit the immune response by activating neutrophils, dendritic cells and macrophages. The macrophage response occurs through activation of intracellular signaling pathways, especially the MAPK pathways, which are crucial due to its ability to phosphorylate a network of proteins that lead to cellular proliferation, differentiation, inflammation and apoptosis. Three families make up the MAPK pathways: ERK, JNK and MAPK p38. Objectives: To evaluate in macrophages the signaling pathways MAPKP38, JNK and ERK1/2 inperiodontitis. Methods: This research is based on an experimental study with 60 volunteers ( 30 with chronic periodontitis and 30 without periodontitis), who will be selected at the dental clinic of the UniversidadeEstadual de Feira de Santana. PBMCs will be cultured, with and without inhibition for MAPK p38, JNK and ERK 1/2 pathways and stimulated by the sonicated extract, $\mathrm{rHmuY}$ and the P. gingivalis K peptide (Kgp12) of P. gingivalis. The measurement of cytokines in the culture supernatant will be done by flow cytometry. The data obtained will be evaluated using the ANOVA tests and the Games-Howell post-hoc tests. Expected results: Thus, this study is expected to contribute to a better understanding of the role of MAPK pathways in the induction of periodontal inflammation by Porphyromonasgingivalis.
\end{abstract}

Keywords: Porphyromonasgingivalis; Signaling pathways; Macrophages; Gingipaína; HmuY.

Support: CAPES; LABIMUNO;PPGIm;NUPPIM.

\section{EVALUATION OF MICROBIOLOGICAL AND IMMUNOLOGICAL MARKERS IN THE ASSOCIATION BETWEEN CHRONIC PERIODONTITIS AND METABOLIC SYNDROME.}

\author{
Patricia Mares de Miranda, Rebeca Pereira Bulhosa Santos, Michelle Miranda Lopes Falcão, Johelle De Santana \\ Passos Soares, Soraya Castro Trindade ${ }^{1}$ \\ ${ }^{1}$ Department of Health, Dentistry, Feira de Santana State University, Bahia, Brazil.
}

Introduction: Metabolic Syndrome (MetS) is a chronic and progressive disease related to pathophysiological changes caused by central fat deposition and insulin resistance. Currently, it contributes to increased cardiovascular morbidity and mortality and type 2 diabetes mellitus. Regarding the factors associated with MetS, some investigations have indicated that its development depends on a complex interaction between genetic predisposition, lifestyle, and socio-demographic factors, as well as health-disease conditions such as insulin resistance, centralized obesity, hypertension, low HDL-cholesterol levels and inflammatory diseases. Periodontitis is a chronic inflammatory process in response to bacterial antigens from the dental biofilm, resulting in loss of tooth Support tissues, alveolar bone resorption and periodontal pockets formation, which may lead to loss of the unit dental. Explanatory theories for 
the association between periodontal disease and MetS have also been presented, migration of buccal bacteria and their byproducts into the circulatory current, with systemic dissemination of inflammatory mediators, such as interleukins (IL-6, IL-1 $\beta$, ) and TNF- $\alpha$ may establish a chronic systemic inflammation. Thus, increased production of circulating metabolites would be related to the causal process of MetS. However, the specific cellular and molecular mechanisms for this association remains unclear. Objective: To investigate the association between microbiological and immunological markers in patients with the diagnosis of MetS and chronic periodontitis. Material and Methods: In this is a case-control study, the microbiological biofilm will be collected from the participants and genotyping will be performed by qPCRto verify the presence and association of periodontopathogens and MetS. In addition, flow cytometry immunoassay will be performed to verify the concentration of Th1, th2 and Th17 profiles cytokines in Porphyromonasgingivalis antigen-stimulated peripheral blood mononuclear cell culture supernatant from individuals withand without MetS.To evaluate the humoral immune response, an enzyme immunoassay (ELISA) will be used to evaluate salivary IgA levels and IgGserum levels specific to antigens present in the sonicated extract of Porphyromonasgingivalis in the comparison groups. Expected Results: The possible association between the immunological and microbiological markers of PD and MetS can contribute to explain the relationship these two chronic diseases.

Keywords: metabolic syndrome, Periodontitis, Immunoglobulin G, Immunogloulin A Acknowledgment: CAPES, FAPESB, LABIMUNO(ICS-UFBA), PPGIm(ICS-UFBA).

\section{EVALUATION OF THE NEUROPROTECTOR POTENTIAL OF FLAVONOIDS BIS-APIGENIN AND APIGENIN ON AMYOTROPHIC LATERAL SCLEROSIS MODELS}

Rodrigo Barreto Carreira ${ }^{1}$, Victor Diógenes Amaral da Silva ${ }^{1}$, Ravena Pereira Nascimento ${ }^{1}$, Lucas Matheus Gonçalves

de Oliveira ${ }^{1}$, Ellen Cristina Vale Silva, Clarissa Schitine1, Maria de Fátima Dias Costa ${ }^{1}$, Cleide dos Santos Souza ${ }^{2}$, Emiliano Trias $^{3}$, Luis Barbeito ${ }^{3}$, Sílvia Lima Costa ${ }^{1}$

${ }^{1}$ Department of Biochemistry and Biophysics, Laboratory of Neurochemistry and Cell Biology, Institute of Health Sciences, Federal University of Bahia, Brazil; ${ }^{2}$ Sheffield Institute for Translational Neuroscience, The University of Sheffield, United Kingdom; ${ }^{3}$ Laboratory of Neurodegeneration, Institut Pasteur Montevideo, Uruguai.

Introduction: Amyotrophic Lateral Sclerosis (ALS) is a fatal neurodegenerative disease characterised by progressive death of the upper and lower motor neurons lidding to the loss of motor function. This disease has a prevalence of approximately 0.6 to 2.6 per 100.000 people, typically fatal within 3 to 5 years of symptom onset. There is no known cure yet, and the current treatments extend the life expectancy only a few months. Indeed, the causes of ALS is unknown there is established that among the pathophysiologic aspects of the ALS are the glutamate-mediated excitotoxicity, oxidative stress and neuroinflammation. Previous research demonstrated in vitro that agathisflavone (bis-apigenin) protects cerebral neurons from inflammatory and glutamate-mediated excitotoxicity. In addition, it was observed that in vitro monomeric apigenin protected cells against induced models of neurodegeneration through immunomodulation of glial cells profile. Objectives: The aim of this project is to characterize the neuroprotector outline of flavonoids agathisflavone and apigenin in ALS models through assessing its effect in aberrant glial cells (Aba); evaluating the motor neuron protection from damage related to ALS; and investigating the flavonoids neuromodulation by assessing the expression and the secretion of cytokines and chemokines from microglial cells. Methods: Will be used Sprague-Dawley SOD1G93A rats as ALS disease model. The anti and pro inflammatory glial cells profile will be assessed by immunohistochemistry of spinal cord sections from treated rats; the motor neuron protection will be evaluated through determining the number and measuring the length of the ChAt+ neurons from treated rats; and the cytokines and chemokines expression and secretion will be determined in treated microglial culture cells derived from ALS. Expected Results: With the development of this project, it is expected to characterize the neuroprotection profile of the flavonoids under study in an ALS neurodegeneration model, with emphasis on its anti-inflammatory mechanisms and in a translational perspective for future therapeutic application.

Keywords: Amyotrophic lateral sclerosis, agathisflavone, apigenin, neuroprotection, immunomodulation.

Support: CAPES - COOPEBRAS (Proc 88881 .368856/2019-01) FAPESB (APP107/2016, INT016/2016-indirect Support). 


\title{
EVALUATION OF THE THERAPEUTIC POTENTIAL OF MESENCHYMAL CELLS THAT OVEREXPRESS IGF1 ON SKELETAL MUSCLE INJURY INDUCED BY INOCULATION OF BOTHROPS SNAKE VENOM
}

\author{
Kaenna Baraúna Campos ${ }^{1}$, Clara Macêdo Mimoso ${ }^{1}$, Luciana Lyra Casais-e-Silva ${ }^{1,2}$, Simone Garcia Macambira ${ }^{1,3,4}$ \\ ${ }^{1}$ Programa de Pós Graduação em Imunologia - Instituto de Ciências da Saúde/Universidade Federal da Bahia. \\ ${ }^{2}$ Departamento de Biorregulação, Laboratório de Neurolmunoendocrinologia e Toxinologia (LABNIET) - Instituto de \\ Ciências da Saúde/Universidade Federal da Bahia. ${ }^{3}$ Departamento de Bioquímica e Biofísica - Instituto de Ciências \\ da Saúde/Universidade Federal da Bahia. ${ }^{4}$ Laboratório de Engenharia Tecidual e Imunofarmacologia - Instituto \\ Gonçalo Moniz/FIOCRUZ/Bahia.
}

Introduction: Skeletal Muscle (SM) regeneration depends on highly complex mechanisms involves different cell types which of them with its own spatial and temporal kinetics. For small muscle injuries, the remodeling process is mainly guide by satellite cells. For massive muscle lesion besides the recruitment of these stem cells, inflammatory cells, fibroblasts, vascular cells and myogenic one are activated. The process is exacerbated and the scar tissue is formed by active fibroblasts, compromising muscle function and structure. Many cytokines and growth factors releases by these cells contribute to healing process such as IGF-1 that is very important to SM regeneration by stimulating protein synthesis, promoting cell activation, differentiation and hypertrophy. However this regenerative potential is limited and overwhelmed demanding therapeutic intervention to avoid functional loss of SM. As Mesenchymal stem cells (MSC) are considered a potential tool for tissue regeneration through paracrine mechanism, so its regenerative capacity could be improved when MSC is overexpressing IGF-1. Objective: To investigate the therapeutic potential of MSC overexpressing IGF-1 on SM damage induced by Bothrops venom inoculation in experimental model. Methods: C57BI6 male mice will be inoculated in hind paw gastrocnemius muscle with $50 \mu \mathrm{g} / \mathrm{mL}$ of the total venom. Animals will be separated in 4 groups: control non-inoculated, venom inoculated MSC-IGF-1(105) treated, venom inoculated MSC (105) treated and venom inoculated non treated. Mice will be submitted to several analysis: functional by treadmill test, serum sinflammatory mediators by ELISA, muscle gene expression of cytokines and growth factors by RTqPCR and structural by morphometric evaluation before and after venom inoculation and after cell therapy. Treatment will be in the acute phase of the lesion ( 6 hafter inoculation) and in the chronic phase ( 3,14 and 28 days after inoculation) and euthanized for further evaluations 24 hafter treatment. Results and Discussion: It is expected to prove the therapeutic potential of MSC overexpressing IGF-1 and to elucidate the immunomodulatory mechanisms involved. Conclusion: Once the effectiveness of this cell therapy is proven, new therapeutic protocols for muscle regeneration can be proposed. Keywords: Mesenchymal stem cells; IGF-1; skeletal muscle; tissue regeneration; poison. Support: CAPES

\section{EXPRESSION AND IMUNNE RESPONSE TO RESUSCITATION PROMOTING FACTOR OFCORYNEBACTERIUM PSEUDOTUBERCULOSIS}

\author{
Natália da Rocha Lopes, Luan Santana Moreira, Vitor Cordeiro Pereira, Marcos Borges Ribeiro, Roberto Meyer, \\ Silvana Beutinger Marchioro
}

Laboratório de Imunologia e Biologia Molecular, Universidade Federal da Bahia - BA, Brasil

Introduction: Resuscitation promoting factors (Rpf) are responsible forbacteria reactivation fromdormant state to active status. In Corynebacterium pseudotuberculosis genome has already been observed the presence of rpf gene, but its importance is unknown yet. InMycobacterium tuberculosis, Rpf are very important and well characterized then, tounderstandhowRpfis involved in patogenesiscaused by $C$. pseudotuberculosisisnecessary. Objectives: Evaluate the expression of Rpfintwodifferent strains (1002 and Cap76)of $C$. pseudotuberculosis, as well as, evaluate the aspects of immune response induced byRpf recombinant antigen. Methods: The Rpf expression evaluation will be done by collecting and samples from the bacteria in different growth phases and subjected to different stress conditions.In each phase, aliquots will be takenand RNA will be extracted for analysis of $r p f$ expression by qRT-PCR. Recombinant protein will be produced by plasmid containing rpfgene and expressed in Escherichia coli. Lastly, indirect ELISA and Western blot method will analyze the response in goat's serum against to rRpf antigen. Expected results: It is expected to characterize the expression of $r p f$ during the cultivation of different strains of $C$. pseudotuberculosis, 
characterizing this expression after the bacteria be subjected to stress factors.It is also expected to characterize the immune response of naturally infected goats to the recombinant Rpf antigen.

Keywords: Rpf; C. pseudotuberculosis; recombinantprotein.

Support: Coordenação de Aperfeiçoamento de Pessoal de Nível Superior (CAPES); Fundação de apoio à pesquisa e extensão (Fapex).

\title{
GENETIC VARIANT IN MIRNA4500 ARE ASSOCIATION WITH ASTHMA AND BRONCHODILATOR RESPONSE
}

Jéssica F de Araúio, HatillaS. Silva, Raisa S. Coelho, Helena M. P. Teixeira, Álvaro A. Cruz, Camila A. Figueiredo, Ryan dos S. Costa

Instituto de Ciências da Saúde, Laboratório de Imunofarmacologia e Biologia Molecular (IMUNOBIO), Universidade Federal da Bahia, Bahia-Brasil.

Introduction: Asthma is generally characterized as an obstructive airway disease that involves chronic inflammation of the respiratory tract. The main treatment is bronchodilation depending on the B2-adrenergic (ADRB2) pathway. The binding of an agonist to the $\beta 2$-adrenoreceptor results in the intracellular elevation of cAMP due to the activation of adenylate cyclase, resulting in bronchodilation. The prevalence, severity of asthma and the search for genetic biomarkers for personalized treatment are on the rise. MiRNA-4500 has shown to present a possible relevant interference in the interference of the ADRB2 pathway, which can be regulatory or deregulating and consequently can be a new therapeutic target. Objective: To investigate the association of polymorphisms in miRNAs. 500 gene with asthmaand lack of bronchial reversibility in asthmatic individuals. Methods: a study was carried out with 1094 adult individuals living in Salvador from ProAR (Program for the Control of Asthma in Bahia. DNA was extracted from peripheral blood and genotyping was performed using the Infinium Multi-Ethnic Global chip and the genetic data from the miRNA, 4500 were extracted. The analyzes were performed using SPSS to define adjustments for logistic regression.The quality control for all SNPS was performed in stages using PLINK. Results: There are 13 SNPs inMIRNA-4500 significantly associated with one of the phenotypes studied Two SNPs were associated as risk factors for asthma, while four SNPs were associated as protective factors in relation to the lack of reversibility in asthmatic individuals. Considering, five SNPs were considered a protective factor. Most SNPS are intronic Conclusion: Variants in miRNA-4500 may influence the patient's chance of responding to short-acting bronchodilator. A further study will allow a greater elucidation of the impact of these variants, which the patient's chance of responding to the short-acting bronchodilator. Further studies will allow a greater elucidation of the impact of these variants, which may contribute to a more effective and personalized therapeutic response.

Keywords: asthma, $\beta 2$-adrenergic pathway, miRNAstherapeutic response.

Support: CNPq.

\section{HETEROLOGOUSPRODUCTION OF RECOMBINANT SCHISTOSOME ELASTASE}

\author{
Carolina Orrico Melo Ferreira de Jesus ${ }^{1,2}$;Beatriz de Souza Santos², Carina Da Silva Pinheiro ${ }^{3}$;Barbara Castro- \\ Pimentel Figueiredo ${ }^{1,2}$ \\ ${ }^{1}$ Postgraduate Program in Immunology, Federal University of Bahia - UFBA. Salvador/Bahia. Brazil; ${ }^{2}$ Serviço de \\ Imunologia do Complexo Hospitalar Universitário Professor Edgard Santos (Com-HUPES), Federal Universityof \\ Bahia - UFBA. Salvador/Bahia. Brazilç3Postgraduate Program in Biotecnology, Federal Universityof Bahia - UFBA. \\ Salvador/Bahia. Brazil.
}

Introduction: Schistosoma mansoni is the parasite that causes schistosomiasis, a disease occurring in a large endemic in Brazil, which reports close to seven million infected individuals. S. mansoni parasite presents a complex life cycle and infection of vertebrate hosts occurs through the active penetration of cercariae through the skin. This process involves the vibratory action of cercaria's tail and also the emptying of the acetabular glands, which promotes the secretion of 
Iytic proteases that assist in the penetration of host intact skin. Previous studies have characterized several proteins in cercariae secretion, being the serine protease elastase (SmCE) the most abundant protein and also the most important protease in active penetration of skin. In addition, cercariae antigens are identified as possibly responsible for immediate immune response after host infection, especially in individuals that have not had previous contact with $S$. mansoni antigens. Objective: Perform a functional study of $S m C E$ enzyme and evaluate its effect on cell activation and cytokine production in uninfected individuals. Material and Methods: Experiments were designed in order to heterologously produce cercaria most abundant elastase isoform, SmCE 1a. After that, its enzymatic characterization was carried out using chromogenic substrate for elastase. Results and Discussion: As a result, recombinant SmCE was expressed Rosetta E. coli strain. After purification, the obtained protein was submitted to enzymatic tests. Considering the conditions tested up to now, the best activity was obtained using the $20 \mu \mathrm{g}$ of protein, after $360 \mathrm{~min}$ of incubation with the substrate at 37 o $\mathrm{C}$, at $\mathrm{pH}$ 9.0. Conclusion: Further experiments will outline $\mathrm{SmCE}$ 1a functionality in buffer containing $\mathrm{Ca}^{2+}$. In addition, we intend to test the effect of elastatic activity inhibitors, such as tosyl-L-phenylalaminechloromethyl ketone (TPCK) and elafine, as well as the SmKI-1 protein from S. mansoni, recently characterized as a neutrophilic elastase inhibitor. Still, we intend to study the effect of SmCE effect on cellular activation and cytokines production by peripheral blood mononuclear cells from uninfected individuals, for a better comprehension of cercarial dermatitis mechanisms.

Keywords: SmCE; elastase; S. mansoni; cercaria.

Support: Fapesb, CNPQ.

\title{
HOMER2 GENE VARIANTS ARE ASSOCIATED WITH BDR IN ASTHMATICS
}

\author{
Helena M.P. Teixeira ${ }^{a}$, HátillaSantos ${ }^{a}$, Ana Paula Castro ${ }^{a}$, Talita S. Jesusa, Maria B. R. de Santana , Gabriela P. \\ Pinheiro ${ }^{b}$, Álvaro A. S. Cruz ${ }^{b}$, Ryan S. Costa ${ }^{a}$, Camila A. Figueiredo ${ }^{a}$
}

${ }^{a}$ Departamento de Biorregulação, Laboratório de Imunofarmacologia e Biologia Me olecular, Instituto de Ciências da Saúde, Universidade Federal da Bahia, Bahia, Brasil. ${ }^{b}$ Programa para o Controle da Asma na Bahia (ProAR), Universidade Federal da Bahia (UFBA), Bahia, Brasil.

Introduction: Asthma is a complex, heterogeneous and variable disease, usually characterized by chronic inflammation of the airways. The first line of treatment for asthma rescue is the use of bronchodilator. HOMER2 is postsynaptic density scaffolding protein whichis a member of homer family and regulates G-protein-coupled receptors such as $\beta 2$ adrenergic receptor, and aids in coupling of surface receptors. Objectives: To identify whethergenetic variants in the HOMER2 gene are associated withbronchodilator response (BDR) in anadmixture population with asthma. Methods: We performed an association test to identify genetic variants that may contribute to differences in acute BDR to inhaled $\beta 2$-agonists, characterized by the change in forced expiratory volume in one second (FEV1). Single-nucleotide variants (SNVs) in HOMER2were genotyped with the Multi-Ethnic Global Array (Illumina) in 716 individuals with asthma from the Programa de Controle da Asma e da RiniteAlérgicana Bahia (ProAR). We used logistic regression models adjusting for age, sex, body mass index (BMI), FEV1 pre-bronchodilator, asthma severity, and genetic ancestry. Results and Discussion: We identified seven SNVs in the HOMER2 associated with BDR.Three variants, rs3784377 (G, OR: 0.62, IC: 0.46-0.83), rs12148275(A, OR: 0.63 IC: 0.47-0.84), rs11393166 (C, OR: 0.64 IC: 0.47-0.85), were negatively associated with BDR which means that individuals who have the alternative alleleshave less chance of responding to bronchodilator. Four variants, rs2667385 (G, OR: 1.32 IC: 1.01-1.72), rs115483400 (C, OR: 1.51 IC: 1.14-2.00), rs1256439(A, OR: 1.67 IC: 1.28-2.18), rs78086831 (G, OR: 2.42 IC: 1.04-5.59)were positively associated which means that they is more likely to respond to the bronchodilator. Variants in the HOMER2 gene have already been associated with FEV1 / FVC rate and vital capacity (FVC). This gene has also been reported as a negative regulator of $T$ cell activation through NFAT. Conclusions: These findings suggest the HOMER2variants associated with BDR could beinvolvedlung function andimmunological pathway, and consequently influence in some way the smooth muscle relaxation that occurs in asthma. Our study expands the understanding of pharmacogenetic analyses provided potentially new insight into biological mechanisms associated with BDR in admixture populations.

Keywords: HOMER2, BDR, asthma, immunogenetics.

Support: This study was financed in part by the Coordenação de Aperfeiçoamento de Pessoal de Nível Superior Brasil (CAPES) - Finance Code 001 


\title{
IDENTIFICATION OF NATURAL POLYPHENOL AND SYNTHETIC DERIVATIVES AS NEW CANDIDATES FOR THE TREATMENT OF SARS-COV2 INFECTIONS BASED ON THEIR NEUROPROTECTIVE IN PRECLINICAL MODELS OF NEUROINFLAMMATION.
}

\author{
William Douglas Lacerda Novais, Clarissa Schitine, Juciele Valéria Oliveira, Maria de Fátima Dias Costa, Balbino Lino \\ dos Santos, Ravena Pereira Nascimento, Victor Diógenes Amaral da Silva, Silvia Lima Costa \\ Laboratório de Neuroquímica e Biologia Celular, Departamento de Bioquímica e Biofísica, Instituto de Ciências da \\ Saúde, Universidade Federal da Bahia (UFBA), Brazil.
}

Introduction: Since the beginning of the COVID-19 pandemic, the number of cases has increased exponentially. In the most severe cases of the disease, patients have a severe acute respiratory syndrome, which can progress to severe pneumonia and even multiple organ failure. In addition, the nasal route is one of the main pathways for the virus to enter the body, thus causing neurological impairment of the central nervous system (SCN). In addition, studies have shown the possibility of brain regions infected with SARS-CoV2 to induce reactive astrogliosis and microglia activation, placing the modulation of the glial inflammatory response as a strategy to contain neurological damage and subsequent damage in other systems. Objectives: The present study has as objective to identify natural polyphenols and synthetic derivatives as new candidates for the treatment of SARS-CoV2 infections based on their neuroprotective effects in preclinical models of neuroinflammation associated with viral infection. Methods: Initially, a panel of 5 natural flavonoids and 10 synthetic heterocyclic derivatives will be tested in concentrations ranging from 0.1 to $10 \mu \mathrm{M}$ in dissociated midbrain cultures subjected (or not - control) to inflammatory damage with IL1- $\beta$ (10 $\mathrm{ng} / \mathrm{mL})$, IFN- $\gamma(100 \mathrm{U} / \mathrm{mL})$ and/or LPS $(10 \mu \mathrm{g} / \mathrm{mL})$ associated with virus infection, and also with recombinant viral protein (100 nM / mL). In order to analyze the neuroprotective effect of these compounds, experimental tests of cell viability and neuron integrity will be carried out by MTT test, Alamar-Blue staining and FluorJade-B staining. The compound that present low neuron toxicity and the best neuroprotector profile against inflammatory damages, will be tested in dissociated and organotypic midbrain cultures, aiming to characterize the inflammatory profile and glial response. For This, immunocytochemistry for astrocyte (GFAP) and microglia (Iba-1) marker will be performed and RT-qPCR for inflammatory cytokines and growth factors. Expected Results: With the development of of this project It is expected to determine new neuroprotective compounds, purified from the regional flora or its derivatives, against inflammatory damage associated with viral infection in the CNS and their potential use as adjuvants in the treatment of diseases of this nature.

Keywords: neuroinflammation, neuroprotection, COVID-19, flavonoids, synthetic heterocyclic compounds.

Support: FAPESB (APP0107/2016; INT 016/2016 - Indirect Support); INCT Nacional Institute for Translational Neuroscience and INCT for Excitotoxicity and Neuroprotection (MCTI/CNPq)

\section{IMMUNOLOGICAL CHARACTERIZATION OF PATIENTS WITH DIAGNOSIS OF COVID-19 AND RELATIONSHIP WITH MARKERS OF VASCULAR INFLAMMATION AND NEUROINFLAMMATION}

\author{
Nívia Nonato Silva ${ }^{1}$, Maria de Fátima Dias Costa ${ }^{1}$, Victor Diógenes Amaral da Silva ${ }^{1}$, Clarissa Schitine ${ }^{1}$, Balbino Lino \\ dos Santos ${ }^{1}$, Ravena Pereira Nascimento ${ }^{1}$, Vitor Antônio Fortuna², Silvia Lima Costa ${ }^{1}$ \\ ${ }^{1}$ Laboratory of Neurochemistry and Cellular Biology, Institute of Health Sciences, Department of Biochemistry and \\ Biophysics, Federal University of Bahia, Bahia, Brazil. '2 Laboratory of Immunology and Molecular Biology, Institute of \\ Health Sciences, Federal University of Bahia, Bahia, Brazil.
}

Introduction: Coronavirus disease 2019 (COVID-19) has now spread quickly worldwide. In addition to major respiratory distress, characteristic neurological manifestations are also described, for example, encephalitis as well as reactive astrogliosis and microglia activation. Furthermore, histopathological studies have emphasized the crucial role of endothelial cells in severe SARS-CoV-2. Events like, venous thrombotic, pulmonary embolism, with elevated D-dimer and coagulation activation are highly prevalent in COVID-19 patients. Objectives: The study will aim to characterize the immunological profile of patients diagnosed with COVID-19 and the relationship with vascular and 
neuroinflammatory markers as a basis for prospecting for new therapeutic approaches. Methods: In the present study, ECA2 and GFAP levels will be analyzed by ELISA, as well as the profile of total leukocytes in blood samples of infected patients. On the other hand, the gliomodulatory effect of a panel of natural flavonoids and synthetic derivatives will be tested in cultures of human astrocytic cells subjected to inflammatory damage associated with virus infection. Cell viability will be measured using the MTT assay and AlamarBlue blue reagent. Astrocyte activation markers, as well as the inflammatory cytokines and vascular factors will be tested by immunocytochemistry and/or RT-qPCR. Expected Results: Characterization of the inflammatory profile, astrocytic response and vascular markers associated with SARS-CoV-2 in view of translation of possible candidates for treatment of SARS-CoV-2. Keywords: COVID-19, astrocyte, neuroinflammation, vascular endothelium. Support: FAPESB (APP0107/2016; INT 016/2016 - Indirect Support); INCT Nacional Institute for Translational Neuroscience and INCT for Excitotoxicity and Neuroprotection (MCTI/CNPq); CAPES (MPhil fellowship).

\title{
IMMUNOLOGICAL RESPONSE LIVER MITOCHONDRIAL OXYGEN CONSUMPTION OF BROILERS FED SUPPLEMENTED ZINC DIETARY
}

\author{
Tatiane Almeida Viana Lopes ${ }^{1}$; Jerônimo Ávito De Brito²; Alexandre Moraes Pinheiro². \\ 1-Programa de Pós-Graduação em Imunologia, Instituto de Ciências da Saúde (ICS), Universidade Federal da Bahia \\ (UFBA), Salvador, Bahia, Brazil; 2- Laboratório de Bioquímica e Imunologia Veterinária, Universidade Federal do \\ Recôncavo da Bahia - (UFRB) Cruz das Almas, Bahia, Brazil
}

Introduction: Zinc $\left(\mathrm{Zn}^{2+}\right)$ is a trace element that is involved in several numerous biological functions due to it is a cofactor of a large number of enzymes. It has antioxidant effect and is crucial for the development of the immune system. In broilers, the immune response can be influenced by the nutritional levels or diet ingredientes. Objectives: The aim of this study was to evaluate the effect of supplementing diet supplemented with $\mathrm{Zn}^{2+}$ on cellular and humoral responses and mitochondrial metabolism in broilers. Material and Methods: A total of 1, 248 day-old broilers was randomly distributed to one of 6 dietary treatments: T1- Control (Basal diet without supplement al zinc); T2 (50mg/Kg of zinc oxide); T3 (100mg / Kg of zinc oxide); T4 (25 mg / Kg of Zincglycinate -Zn Gly); T5 (50 mg/ $\mathrm{Kg}$ of Zn-Gly) and T6 (100 mg/Kg of Zn-Gly). Each treatment was replicated in 48 cages of 26 broileres per cage in a period of 38 days. A peripheral mononuclear cells culture was performedat 12 days of age, in 6 birds per treatment, to verify the production of nitric oxide andthe MTT test. In addition, the assessment of liver oxygen consumption andthe response of cutaneous basophils in response to phytohemagglutinin-P test and measurement of the weight lymphoid organs (spleenand Bursa of Fabricius), at 21, 28 and 31 days of age respectivelywith 8 birds per treatment. Results and Discussion: Nitric oxide production in response to LPS increased in most treatments with zinc, especially (T6). Through the MTT test, greater cell proliferation can be observed in treatments (T3) and (T4) compared to the control. There was no significant difference between treatments in the response of cutaneous basophilstophy to hemagglutinin. However, a significant effect was observed on the relative weight of the Bursa of Fabricius with the supplementation of the organic form of zinc $(p<0.05)(T 4)$. Conclusions: The results suggest that supplementing the diet of broilers with zinc maybe beneficial to the immune system of these animals mainly using the organic source of this mineral, the $\mathrm{Zn}^{2}{ }^{+}$glycinate.

Keywords: immune system, broilers, zinc.

Support: CAPES; UFRB. 


\title{
IMMUNOMODULATION OF THE ETHANOLIC EXTRACT OF PHYALIS ANGULATA ON MICRÓGLIA CELL CROPS INFECTED BY NEOSPORA CANINUM
}

\author{
Washington Santos Antunes ${ }^{1,2}$, Silvia Lima Costa ${ }^{2}$, Alexandre Moraes Pinheiros $^{1}$. \\ ${ }^{1}$ Veterinary Biochemistry and Immunology Laboratory, Federal University of Recôncavo da Bahia, Bahia, Brazil. \\ ${ }^{2}$ Neurochemistry Laboratory, Neurochemistry Laboratory, Federal University of Bahia, Salvador, Bahia, Brazil.
}

Introduction: Neosporosis is a disease caused by the intracellular protozoan Neospora caninum, which can affect various species of animals, including companion and production animals, causing reproductive disorders, neuromuscular changes. In the host, the parasite can infect different tissues, however, they have tropism for tissues of the central nervous system (CNS), where tissue cysts are observed more frequently. There is no effective treatment for neosporosis. The parasite induces a Th1-type response, which causes the synthesis and release of pro-inflammatory molecules. Regulatory cytokines can reshape the Th1 to Th2 response, contributing to the nonprogression of tissue damage caused by the mediators of the Th1 response. P.angulata is a plant with important pharmacological properties, such as anti-inflammatory, antioxidant and neuroprotective action. Objectives: Evaluate the effects of the crude ethanolic extract of Physalis angulata (EEPA) in cultures of microglial cells infected with tachyzoites of $N$. caninum. Methods: EEPA will be produced by the stems of the P.angulata, properly cleaned and macerated in ethanol. The microglia cells will be obtained from the cortex of newborn mice. The cells will be exposed to EEPA in different concentrations for $24 \mathrm{~h}$ and then will be infected with $\mathrm{N}$. caninum tachyzoites for $72 \mathrm{~h}$. The cytotoxicity of EEPA will be determined using the 3- (4, 5-dimethylthiazolyl-2) -2, 5-diphenyltetrazolium (MTT) assay. The changes and microglial proliferation will be assessed by immunostaining of the calcium binding adapter molecule 1 (IBA-1) and the cell proliferation marker, 5-bromo-2'-deoxyuridine (BrdU) synthetic thymidine nucleotides. IBA-1 expression will be evaluated using the Western blotting technique. The level of nitrous oxide will be determined by measuring the nitrite using the Griess method. TNF levels will be determined using the sandwich ELISA assay method using a commercial kit (Invitrogem, Canada). The results will be analyzed by the statistical program GraphPadPrism 5.10 (California, USA) and the data will be expressed in mean \pm mean standard error of the evaluated parameters. Expected results: Identify a fraction of the extract of $P$. angulata capable of promoting an immunomodulatory action in the microglial cells of rats, in the face of experimental infection by the protozoan N.caninum.

Keywords: Central Nervous System, Neosporosis, Microglial cells, Phytotherapic.

Support: CAPES.

\section{INFLUENCE OF TEMPERATURE AND ANTIPYRETIC USE ON CELL VIABILITY IN PRIMARY CNS CROPS OF NEONATE RATS}

\author{
Itamara Raquel dos Anjos, Silvia Lima e Costa ${ }^{1}$, Clarissa Schitine, Denis de Melo Soares. \\ ${ }^{1}$ Laboratory of Neurochemistry and Cell Biology, Department of Biochemistry and Biophysics, Institute of Health \\ Sciences, Federal University of Bahia, Salvador, Bahia, Brazil. \\ ${ }^{2}$ Departament of Medication, Faculty of Pharmacy, Federal University of Bahia, Brazil.
}

Introduction: Several neuropathological manifestations can be characterized by oxidative stress and exacerbated inflammatory response. One constituent part of the inflammatory processis the occurrence of fever, especially in the acute phase of several infections in which there are pyrogenic stimuli. The febrile symptom is, representedby the controlled rise in temperature and has a relevant role in the immune system stimulation.Neurogenesisoccurs in two main regions: the subventricular zone (SVZ) of the lateral ventricle and the subgranular zone (SGZ) of the hippocampal dentate gyrus (DG).The process is a highly complex, with multistep that begins with the proliferation of progenitor cells, is followed by commitment to a neuronal phenotype and ends with the existence of a newly functioning, integrated neuron. Fever induced by viral infections could compromise cell migration, proliferation and differentiation, causing irreversible damage during CNS formation and maturation.Therefore, in pregnant woman, fever could compromise neural formation and cause several neurological pathologies to the embryo. In this context, it is necessary to study drugs that have neuroprotective potential and could prevent these clinical manifestations. 
Objectives: This work willevaluate the influence of high temperature and the use of antipyretics on inflammatory and cellular responses in the main neurogenic niches of CNS. Material and Methods: Primary cultures of two different brain regions, the subventricular zone and the hippocampus, from C57BL / 6 mice which will be prepared. The cultures will be carried out at different developmental stages and will be subjected to induction of several range of thermal stress and subjected to treatment with antipyretic. After this, biological tests will beperformed to assess astroglial reactivity, cell viability, cell proliferation, cell differentiation death. Moreover, the expression of inflammatory and regulatory interleukins during the process will be measured. Results: It is expected that we can characterize both inflammatory events, as well as the neurogenesis process through exposure to elevated temperatures and the possible protective effect that can be caused by the modulation generated by antipyretics in the CNS development stages. In addition, weaimtoelucidatethese effects on neural formation.

Keywords: Neurogenesis. Heatstress.Antipyretic.Neuroinflammation.

Support: Coordenação de Aperfeiçoamento de Pessoal de Nível Superior - CAPES.

\title{
INFLUENCE OF TRYPANOSOMA CRUZI COINFECTION ON THE IMMUNE RESPONSE AND CLINICAL OUTCOME OF PATIENTS WITH CUTANEOUS LEISHMANIASIS FROM THE ENDEMIC AREA OF CORTE DE PEDRA-BAHIA, BRAZIL
}

\author{
Mônica Sousa Pita ${ }^{a}$, Andréa Santos Magalhães ${ }^{a, c}$, Lucas Pedreira de Carvalho ${ }^{a, b, c}$ \\ almmunology Service, UniversityHospital, Universidade Federal da Bahia, Brazil, ${ }^{b}$ PostgraduateProgram in \\ Immunology, Universidade Federal da Bahia, Brazil, 'ClinicalResearchLaboratory (LAPEC), Gonçalo Moniz Institute, \\ Fiocruz-Bahia, Brazil.
}

Introduction.AmericanTegumentary Leishmaniasis (ATL) is a disease that presents wide complexity in different aspects, and may result from the interaction between the patient's immune response, the genetic characteristics of the species involved in the infection, epidemiological aspects of the endemic area and possible coinfections. In several areas of Latin America, the geographical distribution of cutaneous leishmaniasis overlaps with areas of transmission of T.cruzi ranging from 12 to $70 \%$ of patients with clinical symptoms for leishmaniasis. (Gil, José.F., 2016). A higher T cell differentiation profile has been observed in patients with cutaneous and mucosal leishmaniasis infected with T. cruziwhen compared to patients only infected with Leishmania (Bracco, María M. de Elizalde de. 2016). Objectives. To assess whether the immune response of patients with cutaneous leishmaniasis caused by $L$. braziliensis and co-infected by T. cruzi is associated with the poor clinical outcome. Material and Methods.This is a case-control study in which patients with cutaneous leishmaniasis caused by L. braziliensis, living in an endemic area of Corte de Pedra, Bahia, were recruited. Two-hundred serum were evaluated for specific IgG T.cruzi proteins by ELISA technique. Results and Discussion. Twenty patients who were coinfected and twenty patients only infected with Leishmania were evaluated. Coinfected patients had higher IgG1 and IgG3 antibody titers compared to patients only infected with Leishmania. In addition, among patients who failed the first leishmaniasis treatment cycle, IgG3 levels were higher in co-infected patients compared to those infected only by L. braziliensis. Conclusions. These results indicate that coinfection may interfere with the individual's immune response to Leishmaniainfection.Keywords: leishmaniasis, Chagas disease, coinfection.

Keywords: Leishmaniasis, symptoms, coinfection.

Support: National Institute of Science and Technology - Tropical diseases (INCT-DT). 


\title{
LYMPHOCYTE PROFILE IN ACUTE MYELOID LEUKEMIA AT DIAGNOSIS AND AFTER INDUCTION THERAPY
}

\author{
Reis R, Santos MM, Santos AS, Santos HHM, Santos LS, Almeida BL, Peralva CMS, Meyer R, Freire SM \\ Laboratório de Imunologia e Biologia Molecular - ICS-UFBA, Salvador - Brazil
}

Introduction: The role of the immune cells in hematological neoplasms is not fully understood of ar. Since the cytolytic activityof Natural Killer (NK) cells and the interaction of B and T lymphocytes seem to inhibit the development and progression of neoplastic cells, this study aimed at analyzing the distribution of subsets of lymphocytes in individuals with Acute Myeloid Leukemia (AML) at diagnosis and after induction therapy. Methods: This preliminary study included 13 participants diagnosed with new AML. Peripheral blood samples were collected at diagnosis and at day 21 afterin itiation of induction therapy. The lymphocytes' subsets were analyzed using the FACS Canto II тм flowcytometer and the Infinicyt ${ }^{\mathrm{TM}}$ software. Results: The median percentage of $\mathrm{T}$ lymphocyte safter induction (25.76\%) was higherth an at diagnosis (10.86\%). The median CD4/CD8 ratio was also increased after induction (1.87) compared to the diagnosis (1.37). On the other hand, the median percentage of B lymphocytesand NK cells, respectively, was higher at diagnosis $(1.66 \%$ and $2.40 \%)$ compared to the endof induction therapy $(0.09 \%$ and 1.17\%). Discussion: The cell-mediated immune response plays a Key role in fighting neoplasms. The infiltration of lymphocytes with in the tumor microenvironment has been associated with a better prognosis and therapeutic response. In this study, the increased amount of T lymphocytes at the endof induction highlights its importance in theanti-leukemic response. According to Park et al. (2018), an increaseof NK cells ( $\geq 5 \%)$ in the blood is associated with an improved survival, as patients with a low percentage of NK cells also tend to have higher rates of relapse. A decrease in the number of B lymphocytes was also observed. This subtype of cells may reflect the over all health of the bone marrow, and it is associated with better prognosis as well. Conclusion: In AML, the distribution of lymphocyte subsets differs at diagnosis and after in duction therapy. These partial findings, in association with other immunological, clinical factors and additional molecular characteristics, may contribute to a better underst and in gof the role of the immune system in the progression and clinical outcome of patients with this hematological neoplasm.

Keywords: Acute Myeloid Leukemia, Lymphocyte, InductionTherapy

Support: CAPES

\section{MODULATORY EFFECTS OF MAGNETIC STIMULATION IN ASTROCYTES: A NEUROINFLAMMATORY STUDY}

\author{
$\underline{\text { ANA ELISA DEL'ARCO }}^{1,2,3}$; SILVIA LIMA COSTA ${ }^{3}$, DEIVISSON SILVA ARGOLO ${ }^{1,3}$; GIZELLE ALVES PINA ${ }^{3}$; MARIA DE FÁTIMA \\ DIAS COSTA ${ }^{3}$;ALEXANDRE MORAES PINHEIRO²
}

${ }^{1}$ Postgraduate Program in Immunology, Federal University of Bahia; ${ }^{2}$ Biochemistry and Immunology Laboratory, Federal University of Recôncavo of Bahia; 3. Neurochemistry Laboratory, Federal University of Bahia

Introduction: Magnetic stimulation (MS) is a technique based on electromagnetic theory and has been studied to treat psychiatric and neurologic disorders and to assess the cognitive function of nervous system. Many researches have been produced to achieve this knowledge, but few works were developed to know the cellular effect in inflammation of central nervous system. Objectives: The aim of this study was to investigate the role of magnetic stimulation in a neuroinflammation model in astrocytes. Material and Methods: Astrocytes were obtained from the cortex of newborn rats $(<48 \mathrm{~h})$ and the culture was maintained in supplemented DMEM (Dulbecco's modified Eagle's medium). After 10 days, the microglial cells were removed and astrocytes were plated in 24 wells plates. Cultures were treated with $1 \mu \mathrm{g} / \mathrm{mL}$ of LPS diluted in culture medium. Cultures without LPS were maintained as control. After 6 hours of treatment, MS treatment was performed in the cultures in room temperature with intensity of $0,62 \mathrm{~T}$, at $10 \mathrm{~Hz}$ for $30 \mathrm{~s}$ with repetitive pulse. This procedure was repeated once a day for 3 days and plates without MS treatment were used as control. Cytotoxicity was determined using MTT and nitric oxid (NO) tests, and the cells was photographed in contrast phase microscope. Results and Discussion: The MTT results shownMS groups with lower viability: less $5,46 \%$ in astrocytes plus MS, and less $13,44 \%$ inLPS plus MS group. The production 
of NO ( $\mu \mathrm{g} / \mu \mathrm{g}$ of protein) was 5, $98 \times 10-5$ in the control (astrocytes only), 4, 94x10-4astrocyte plus MS, 1, 54x102toLPS and9, 2x10-3to LPS plus MS. The difference was statistically significant between the groups: astrocyte and LPS with their respectively MS group.Studies of the cultures images suggest a decrease in gliosis in LPS group after magnetic stimulation treatment. Conclusion: MS reduces nitric oxid production and gliosis in astrocyte inflammation model.The reduction of viability could suggest a decrease of immune activated cells, controlling the inflammation. Keywords: MTT, nitric oxid, repetitive magnetic stimulation.Financial Support: CAPES, FAPESB, CNPq, INCT.

\title{
NANOVACIN DEVELOPMENT USING RECOMBINANT PROTEINS OF CORYNEBACTERUIM PSEUDOTUBERCULOSIS LINKED TO POLYMERIC NANOPARTICLES
}

\author{
Vitor Cordeiro Pereira, Natália da Rocha Lopes, Luan Moreira Santana, Vagner de Oliveira Machado, \\ Marcos Borges Ribeiro, Roberto Meyer, Silvana Beutinger Marchioro \\ Postgraduate Program in Immunology, Federal University of Bahia; Immunology and Molecular Biology Laboratory, \\ Federal University of Bahia
}

\begin{abstract}
Introduction: Caseous lymphadenitis (CLA) is acontagious infectious disease caused by Coryne bacterium pseudo tuberculosis. This disease leads to impacts in Brazilian agribusiness and, indirectly, public health. It is characterized by chonic clinical signssuch as suppurative abscesses in subcutaneous tissue, lymph nodes and vital organs. The control of the disease by means of vaccines is fundamental, but this control is affected by limitations of protection of the current vaccines, which motivate the development and production of efficient vaccines and with a higher degree of protection. Objective: To evaluate the immune protective capacity of recombinant antigens ( $\mathrm{NanH}$ and $\mathrm{PknG}$ ) of C. pseudo tuberculosis linked to polymeric nanoparticles of tri-methylene carbonic polyacetic acid (PLDLA-co-TMC/ Twenn 80). Method: Synthetic version of genes encoding proteins of $C$. pseudo tuberculosis, with optimized códons for expression in heterologous systems and cloned into Eschericheacoli vector for the production of the proteins. Nano vaccines formulatios will be synthetized via interfacial deposition with changes in the organic/aqueous phase and characterized in terms of their size, stability and surface load. BALB/C mice will be grouped in seven experimental groups to evaluate the immunogenic potential of nanovacins. Expected results: We intend to find significant results in the immuno protection with the nanovacins against $C$. pseudo tuberculosis. Indirect ELISA analyzes wille valuate the production of specific IgM and IgG antibodies against vaccine antigensin the immunized groups. Levels of gamma interferon and cytokines will quantify in each experimental group to determine the profile of immune response induced by the nanovaccines.
\end{abstract}

Keywords: Caseous lymphadenitis, reverse vaccinology, nanovaccines

Support: Labimuno/ICS/UFBa, Fapex, Capes

\section{NICOTINE INHIBITS AMINOCHROME-INDUCEDIN VITRO CYTOTOXICITY: PERSPECTIVES FOR APPLICATION IN PARKINSON'S DISEASE}

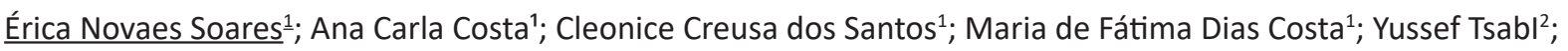 \\ Silvia Lima Costa ${ }^{1}$; Victor Diogenes Amaral da Silva ${ }^{1}$ \\ ${ }^{1}$ Laboratory of Neurochemistry and Cell Biology, Department of Biochemistry and Biophysics, Institute of Health \\ Sciences, Federal University of Bahia, Salvador, Bahia, Brazil. ${ }^{2}$ Department of Pharmacology, Howard University \\ College of Medicine, 520 W Street NW, Washington, DC 20059, USA
}

Introduction: Parkinson's disease (PD) is a neurodegenerative disorder that affects brain tissue, especially midbrain dopaminergic neurons. The loss of dopaminergic neurons result in low levels of dopamine and motor symptoms such as dyskinesia, muscle stiffness, posture instability and tremors at rest, which appear after years of degenerative processes and can be preceded by non-motor symptoms such as olfactory and mood disorders. Studies have been suggested aminochrome as an endogenous neurotoxin responsible for the dopaminergic neuron degeneration in PD. It is a natural molecule in dopaminergic neurons derived from dopamine oxidation that has been used as inductor of 
PD study model. On the other hand, studies have been demonstrated that nicotine protects neuronal cells against aminochrome-toxicity. Objective: The aim of this study was to evaluate the effect of nicotine on neuroprotection and glial cell response in in vitromodel of Parkinson's disease induced by aminochrome. Methodology: Primary microglia cultures was obtained from neonatal Wistarrats (0-2 days) cortex andmixed primary cultureswas obtained from Wistar rat embryos (15 - 16 days)midbrain as described in the approved protocol CEUA 127A/2017 for animal use in experimental procedure. The mixed primary cultures were treated with $25 \mu \mathrm{Maminochrome} \mathrm{and/} \mathrm{or} 0.01 \mu \mathrm{M}$ or $1 \mu \mathrm{M}$ nicotine for $48 \mathrm{~h}$.Cell viability was performed bypropidium iodide test and cell morphology was analyzed by Rosenfeld's stanning.Theprimary culture of microglia was treated with nicotine at concentrations of $0.01 \mu \mathrm{M}$, $0.1 \mu \mathrm{M}, 0.5 \mu \mathrm{M}$ and $1 \mu \mathrm{M}$ and the cell morphology was analyzed by phase contrast.Results: It was observed that $25 \mu$ Maminochrome induced cell death in primary cultures, moreover0.01 $\mu \mathrm{M}$ and $0.1 \mu \mathrm{M}$ nicotineprevents the cell damage induced by aminochrome. Itwas observed in the microglia culture that the treatment with $0.01 \mu \mathrm{M}$ nicotine showing branched morphology.Conclusion: We concluded that nicotine is not cytotoxic at $0.01 \mu \mathrm{M}$ or 0.1 $\mu \mathrm{M}$ in primary midbrain culture or microglial culture, moreover it protects cells neural cells against aminochrome cytotoxicity. We suggest that more studies must be performed to characterize the mechanism of nicotine action and its effect in glial cells. At the end of the analysis, we expect characterize the effect of nicotine in glial cells and mechanism involved in its protective effect against aminochrome.

Support: FAPESB, CAPES and CNPQ.

Key-words: Nicotine, aminochrome, midbrain, glial cells.

\title{
PERIPHERAL BLOOD CD4 ${ }^{+}$T CELLS PROFILE IN SICKLE CELL DISEASE PATIENTS WITH OSTEONECROSIS
}

\author{
Paula Braga Daltro ${ }^{1}{ }^{2}$; Vitor Antonio Fortuna ${ }^{1,2}$; Roberto José Meyer Nascimento ${ }^{1,2}$. \\ ${ }^{1}$ Post-graduation Program in Immunology, Health Science Institute (ICS), Federal University of Bahia (UFBA), \\ Salvador, Bahia, Brazil; ' 2 Immunology and Molecular Biology Laboratory, ICS, UFBA.
}

Introduction: Osteonecrosis (ON) is a chronic severe complication in sickle cell disease (SCD) resultant of microcirculatory obstruction by sickled erythrocytes leading to bone infarction. Cytokine and T helper cells (TCD4+) play an important role in ON pathophysiology and has been reported to be important in SCD. Cytokine and Thelper cells (TCD4+) profile from SCD/ON patients peripheral blood (PB) remains a challenge. Objective: Here we aimed to assess peripheral blood mononuclear cells (PBMC) TCD4+ phenotype from SCD, SCD/ON and non-SCD (nSCD). Material and Methods: Peripheral blood (PB) from 9 steady state SCD patients, 15 SCD/ON patients and 19 healthy controls $C D 4^{+} T$ cells derived from PBMC were analyzed for CD4, CD8, CD45RA, CD45RO surface molecules and Th1/ Th2/Th17 (in activated PBMC) phenotype. Results and Discussion: We found that PB of SCD patients with or without ON presented significantly reduced TCD4 $4^{+}, \mathrm{TCD} 8^{+}$and TCD4 $4^{+}$naïve cell frequencies [for TCD4 $4^{+}$(T helper) and TCD8 ${ }^{+}(\mathrm{T}$ cytotoxic) co-expressing CD3 marker. Compared with healthy controls, SCD and SCD/ON patients had a significantly lower median distribution of TCD4+ Only SCD subjects had significantly lower median effector T cell proportions than control subjects [21.62\% (range 4.84-41.26) vs10.84\% (range 4.33-16.08), $p=0.05$ ]. We also saw an increase in the number of bi-functional IFN- $\gamma^{+} / \mathrm{IL} 4^{+}$and IL-17+/ IL4+CD4 $4^{+} T$ cells compared to healthy controls. Co-expression of $\mathrm{IL} 17^{+} / \mathrm{IL} 4^{+}$was significantly higher in SCD compared to SCD/ON group $(p=0.0425)$. The increase in IL-4 frequency of expression which may suggest a shift in $\mathrm{CD}^{+} \mathrm{T}$ cell response, corresponding to a Th2 phenotype. Conclusion: Taken together, these data indicate the association of $\mathrm{CD} 4^{+} \mathrm{T}$ cells in pathophysiology of osteonecrosis related to sickle cell disease.

Keywords: T helper cells; Osteonecrosis; Sickle cell disease

Support: FAPESB, CAPES, CNPq 


\title{
POLYMORPHIMS IN IFI16GENEARE ASSOCIATED WITH PERIODONTAL DISEASE IN A POPULATION IN SALVADOR/BA-BRAZIL
}

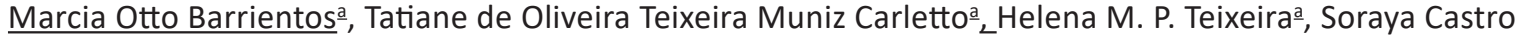 \\ Trindade ${ }^{a}$, Álvaro A. S. Cruz ${ }^{b}$, Camila A. Figueiredoa, Ryandos Santos Costa $\stackrel{\text {. }}{\text {. }}$
}

${ }^{a}$ BioregulationDepartament, Immunopharmacology Laboratory of Molecular Biology, Institute of Health Sciences, Federal University of Bahia, Salvador, Bahia, Brazil. ${ }^{b}$ Program of Control of Asthma and Allergic Rhinitis of Bahia (PROAR), Federal University of Bahia, Salvador, Bahia, Brazil.

Introduction: Interferon inducible protein, IFI16, is a protein with 785 amino acids, of quaternary structure, with 3 isoforms that combine to form oligomers. IFI16 has a HIN-200 domain and another pyrine. It is located mainly in the nucleus, being a transcriptional regulator for the activation of NF-KB activity. One of the functions of this protein is to detect and bind to DNA fragments in the cell cytosol through the HIN-200 domain. Apparently, the presence of cytosolic DNA stimulates the migration of IFI16 from the nucleus to the cytosol to control viral or bacterial invasion, but its route of action is not completely elucidated. The literature shows an association between the gene IFI16 with periodontal disease. This disease characterized by a complex inflammatory process involving pathogenic oral bacteria.Objective: The aim of this study is to verify the association of the genetic variants in IFi16 with the presence of periodontal disease. Methods: Participating in the Program of Control of Asthma and Allergic Rhinitis of Bahia (ProAR) ( $n=396)$, of both sexes, aged $\geq 18$ years, were classified for the presence $(n=72)$ or absence $(n=324)$ of periodontitis, according to the criteria of Gomes Filho et al. DNA genotyping used the Infinium Multi-Ethnic Global chip. Statistical analysis used PLINK 1.9 software, logistic regression in three models additive, dominant and recessive, adjust for smoking habit, age, gender, schooling, obesity, asthma and the main component of sample ancestry, considering the Hardy-Weinberg equilibrium deviation(HWE<0.05) and frequency of the smallest allele (MAF>0.01). Results and Discussion: Thers1417805was associated to severe periodontal disease in the one genetic model evaluated, recessive (OR 3.00, 95\% Cl 1.05-8.57, $p=0.04, p$-perm=0.03).IFI16 have role in inflammation and on innate immunity. Their actions are fundamental for homeostasistherefore, variants in the gene for this protein can result in alteration of pathogens, including those affecting the periodontium. Conclusion: The genetic variant rs 1417805 of the IFI16is associated with the presence of periodontal disease, in recessive model. It is suggested to increase the statistical power by means of a larger sample to confirm these results.

Keywords: Polymorphism, IFI16, periodontal disease.

Supports: CAPES, UFBA 


\title{
PRETREATMENT NEUTROPHIL-TO-LYMPHOCYTE RATIO AS PROGNOSTIC PARAMETER FOR SURGICAL RESECTION IN ADVANCED ORAL SQUAMOUS CELL CARCINOMA PATIENTS
}

\author{
$\underline{\text { Renata Freitas Araujo-Calumby }}{ }^{1,2}$, André Leonardo de Castro Costa ${ }^{3}$, Anna Beatriz Pereira Simões Alves², Camila \\ da Silva Souza1,2, Daniel Nascimento², Deyse Souza Carvalho da Silva², Geovane de Jesus Santos², Gessualdo \\ Seixas Oliveira Junior ${ }^{2}$, Herval Bruno Moreira dos Santos Filho², Matheus Antônio da Hora Borges², Miguel de \\ Jesus Oliveira Santos², Lucianna Stutz Souza Carneiro de Campos², Vitor Silva de Oliveira², Marcus Antônio de \\ Mello Borba ${ }^{3}$, Lucas Gomes Silva ${ }^{3}$, Iguaracyra Araújo ${ }^{3}$, Rodrigo Tripodi Calumby ${ }^{4}$, Silvia Lima Costa ${ }^{1,2}$, \\ Deise Souza Vilas-Bôas ${ }^{1,2}$
}

${ }^{1}$ Post-Graduate Program in Immunology, Federal University of Bahia (UFBA), Salvador-Bahia, Brazil

${ }^{2}$ Institute of Health Sciences, UFBA, Salvador-Bahia, Brazil; 3 Aristides Maltez Hospital (Liga Baiana Contra o Câncer), Salvador-Bahia, Brazil ; 4 Advanced Data Analysis and Management Laboratory, Department of Exact Sciences, State University of Feira de Santana (UEFS), Feira de Santana-Bahia, Brazil

Introduction: Oral Squamous Cell Carcinoma (OSCC) represents the major oral cavity tumor and presents high aggressiveness and metastatic potential. The use of conventional pretherapeutic assessment of cells and serum markers as adjuvants to improve the clinical management of solid tumors has received increasing attention due to its potential to provide prognostic information, acting as low-cost biomarkers. Objectives: To investigate the prognostic value of neutrophils and lymphocytes ratio (NLR), lymphocytes and monocytes ratio (LMR) and platelets and lymphocytes ratio (PLR) in patients who underwent or did not undergo resection surgery in a large cohort of OSCC patients. Methods: A total of 433 OSCC patients who were treated between 2008 and 2017 at Department of Head and Neck Surgery of Aristides Maltez Hospital (Salvador, Bahia, Brazil) were enrolled and evaluated retrospectively in this study. Results and Discussion: During an average longitudinal follow-up period of circa 30 months, the death event occurred in $52.2 \%(n=226)$ of the cases, death by cancer in $49 \%(n=212)$, locoregional recurrence in $24.5 \%(n=106)$ and metastasis in $13.9 \%(n=60)$.In order to investigate whether NLR, PLR and/or LMR were associated with the clinical outcome of patients with OSCC, univariate and multivariate Cox proportional models were calculated for overall (OS), disease-specific (DSS), locoregional-free (LRFS) and distant recurrence-free survival (DRFS). The univariate analysis identified that both high NLR $(\geq 2.1)$ and PLR ( $\geq 131.5)$ or low LMR $(<4.2)$ were significantly associated with worse OS and DSS $(p<0.05)$ although not associated with LRFS or DRFS. However, the multivariate analysis showed thatonly a high NLRpresented an independent prognostic value for OS and DSS. Furthermore, patients inadvanced stage (III and IV) treated with surgical resection exhibited NLR as a prognostic parameter for OS and DSS. Conclusions: The systemic NLR presentspotential as predictive factor for survival in OSCC patients and may influence clinical choices in relation to therapeutic interventionsfor patients with advanced clinical staging.

Keywords: oral cancer, oral squamous cell carcinoma, neutrophil-to-lymphocyte ratio, platelet-to-lymphocyte ratio, lymphocyte-to-monocyte ratio.

Support: CAPES. 


\title{
POLYMORPHISMSRELATED TO TYPE 2 INNATE LYMPHOID CELLS ARE ASSOCIATED WITH ASTHMA AND ATOPY IN A BRAZILIAN POPULATION
}

\author{
Louise C. de Lima ${ }^{2}$, Álvaro A. Cruz², Hatilla dos S. Silva², Raísa S. Coelho², Ryan dos S. Costa², Camila A. V.
} Figueiredo², Vadirene L. Carneiro ${ }^{1}$.

${ }^{1}$ Department of Life of Sciences, State University of Bahia-Brazil. ${ }^{2}$ Department of Bioregulation, Laboratory of Immunopharmacology and Molecular Biology, Federal University of Bahia (ICS), Bahia-Brazil. ${ }^{3}$ Program for the Control of Asthma and Allergic Rhinitis in Bahia (ProAR), Federal University of Bahia (UFBA), Bahia-Brazil.

Introduction: Asthma is a chronic inflammatory disease that impacts the lives of millions of people worldwide. There are several phenotypes and endophenotypes of this pathology, and some are associated with an increase in eosinophils in blood and sputum. This increase may cause greater severity of the disease and studies have shown that this condition may be associated with genes related to type 2 innate lymphoid cells (ILC2). Objectives: The purpose of this work is to evaluate the association between polymorphisms in genes related to ILC2 (TSLP, IL25, GATA3 and RORA) with asthma endophenotypes. Methods: This is an unconventional case-control study, composed of 364 patients without asthma, 412 patients with mild asthma and 401 patients with severe asthma, over 18 years of age, resident in Salvador-BA and belonging to the Asthma and Rhinitis Control Program Allergic in Bahia (ProAR). Four genes were selected for the study and additive logistic regression models were used for all genes, using the software Plink 1.09. Results and Discussion: Eleven SNPs in the studied genes were significantly associated with asthma and atopy variables. rs3806933 and rs11466741 in the TSLP gene demonstrated protective associations with asthma and its severity (OR: $0.79 ; 95 \% \mathrm{Cl}: 0.64-0.96 / \mathrm{OR}: 0.75 ; 95 \% \mathrm{Cl}: 0.61-0.91)$. On the other hand, rs263423 and rs263424 in the GATA3 gene, demonstrated risk associations with asthma (OR: 1.29; 95\%Cl: 1.06-1.57/OR: 1.34; 95\% Cl: 1.03-1.76) and rs3824662, in the same gene, demonstrated a risk association with atopy (OR: 1.53 ; $95 \% \mathrm{Cl}$ : 1.03-2.28). rs12899193 in the RORA gene demonstrated a risk association with asthma severity (OR: $1.44 ; 95 \% \mathrm{Cl}$ : 1.12-1.86), while rs11071557 and rs11071559 of this gene demonstrated protective associations with eosinophilia in asthma (OR: 0.71; Cl95\%: 0.57-0.89/OR: 0.73; 95\% Cl: 0.59-0.90). rs10135798, rs1124053 and rs3811178 in the IL25 gene demonstrated risk associations with atopy markers (OR: 2.10; 95\% Cl: 1.05-4.18/OR: 1.54; 95\% Cl: 1.04-2.29/ OR: 0.66; 95\% Cl: 0.43-0.99).Conclusions: These data demonstrate that variants in the TSLP, IL25, GATA3 and RORA genes cause genetic risk or protection impacts on asthma and its different endophenotypes. However, functional studies are needed to elucidate the mechanisms involved in these results.

Keywords: Phenotypes, Asthma, ILC2, SNPs.

Support: CAPES, CNPq, FAPESB, IMUNOBIO

\section{PROPOSITION OF NATURAL COMPOUNDS AND CHIMERIC PROTEINS FOR NOVEL PROPHYLACTIC METHODS AGAINST STREPTOCOCCUSEQUI}

\author{
Bernardo Mirabal Santos ${ }^{1}$; Sarah Pereira Andrade de Souza ${ }^{1}$, Igor Batista dos Santos Oliveira ${ }^{1}$, Letícia Vivas \\ Carvalho $^{1}$, Nubia Seyffert ${ }^{1}$; Roberto Meyer ${ }^{1}$; Thiago Luiz de Paula Castro'. \\ 'Laboratory of Immunology and Molecular Biology - Institute of Health Sciences, Federal University of Bahia, Bahia, \\ Brazil.
}

Introduction: Equine strangles is a disease that affects the upper respiratory tract, guttural pouch and lymph nodes in horses. The disease is caused by Streptococcus equi, a Gram-positive facultative intracellular bacterium. Novel and promising prophylactics are necessary to control strangles dissemination in herds and prevent substantial economic losses worldwide. In the genome era, prospection of therapeutic drugs and vaccine candidates is facilitated by the use of robust bioinformatics approaches. Objectives: To prospect natural plant compounds with potential use as drugs against $S$. equiand propose a potentially immunogenic chimeric protein for the development of a vaccinefor strangles. Material and Methods: Theoretical proteome sequencesof 19S. equistrains were retrieved from the National Center for Biotechnology Information (NCBI)database. Proteins shared by all strains and non-homologous to equine were identified and subjected to prediction of subcellular localization. Cytoplasmatic proteinspredicted 
to be essential for the bacterium and involved in virulence are beingprospected as potential targets for a library of 5, 000 natural plant compounds using AutoDockVina. Proteins likely exposed on the cell surface or secreted to the environment were selected for epitope screeningusing the IEDB platform. A list of chimeric proteins will be generated using different combinations of epitopes likely recognized by theequine Major Histocompatibility Complex (MHC) I and II. Structural models of these proteins will be predicted using the MHOLlineplatform.Antigenicity, allergenicity, toxicity, physicochemical behaviour, instability, and solubilityfeatures will be assessedin silico. Partial and Expected Results: 247 proteins shared by all 19 S. equistrains were found to be not homologous toequine.Out of these, 134 wereselected as potential drug targetsand are being used for essentiality, virulence involvement and structure prediction. The other 113 proteins were selected as potential vaccine targets. Next, we expect to selectnatural plant compounds withthe best biochemical interactions withthe selected protein targets. We also expect to predict the best immunogenic chimeric proteins for future immunization assays against strangles.

Keywords: Equine; Strangles;Bioinformatics; Molecular docking; Natural compounds; Chimeric protein; Subunit vaccine.

Support: CAPES, CNPq, FAPESB.

\title{
PROSPECTING FOR $N$-HETEROCYCLIC COMPOUNDS TO CHARACTERIZATION OF ANTIGLIOMA ACTION MECHANISMS IN GLIOBLASTOMA CELLS AND IN INTERACTION WITH MICROGLIA
}

\author{
Jéssika Alves Oliveira Amparo', Raimundo Francisco dos Santos Filho², Victor Diógenes Amaral da Silva'; Silvio do \\ Desterro Cunha ${ }^{2}$, Ravena Pereira do Nascimento', Silvia Lima Costa' \\ 'Laboratory of Neurochemistry and Cellular Biology, Department of Biochemistry and Biophysics, Institute of \\ Health Sciences, Federal University of Bahia, Bahia, Brazil. ${ }^{2}$ Research Group in Chemical Synthesis and Molecular \\ Bioactivity, Department of Organic Chemistry, Institute of Chemistry, Federal University of Bahia, Bahia, Brazil.
}

Introduction: Glioblastoma (GBM) is the most aggressive type of brain tumor that affects the central nervous system (CNS) and present resistance to radiotherapy and chemotherapy, thus remaining with the worst prognosis. Microglia are immuno-effector cellsof the CNS, however, they can contribute to the progression of glioma, acquiring immunosuppressive and tumorSupport properties. In the search for new treatments, enaminone-derived molecules, obtained by organic synthesis using Green Chemistry-based principles, have been proposed as compoundsthat exert an inhibitory and immunomodulatory potential to glioma cells growth and proliferation. Objective: The aim of this study was to perform a prospection in vitrooftheeffects of thirty six new enaminone-derived moleculesin terms of cytotoxicity and morphological changesofchemoresistant GBM cells, and select best candidates capable to modulate microglial immunosuppressive profile during interaction with GBM cells. Methods: Human GL-15 GBM cellswere treated with a panel of 36 enaminone-derived molecules at concentration of $100 \mu \mathrm{M}$ or kept in control conditions (0.1\% DMSO).The cell viability and morphology were evaluated after 24 and $72 \mathrm{~h}$ of treatment by MTT assay and by phase-contrast microscopy.The molecules that followed in the next test met the criteria forstronger effect on cell viability, induction of morphological alterations, efficiency on synthesisand absence of precipitation in organic solvents. Four moleculeswere selected and tested in GL-15 and C6 GBM cells and also normal glial cells at concentrations of 1, 10,50 and $100 \mu \mathrm{M}$ or kept in control conditions.After selecting the most promising molecule, the proliferation and phenotypic profile of microglia will be evaluated, as well as the profile of inflammatory and anti-inflammatory cytokines secreted in microglia/glioma co-cultures.Results and Conclusions: The compounds RRF-D468, RRF-D542 and RRF-D610 induced concentration dependent reduction on viability of glioma cells and morphological changessince 24 hafter treatments. However, only the compound RRF-D610 presented selective cytotoxic and morphogenic activity against highly proliferating glioma cells, not affecting the viability of normal glial cells, putting in perspective further studies to investigate immunomodulatory effects during microglia/glioma interactions, to better characterize possible application for GBM adjuvant therapy.

Keywords: Glioma, microglia, nitrogenous heterocyclic compounds, enaminone, cytotoxicity. 
Support: CNPq (Proc. 443723/2014-1, partially); INCT - Nacional Institute for Translational Neuroscience and INCT for Excitotoxicity and Neuroprotection (MCTI/CNPq); FAPESB(MPhil fellowship).

Protective and profibrotic cytokines mediated by $\mathrm{CD} 4^{+} \mathrm{T}$ lymphocytes in periportal fibrosis secondary to schistosomiasis

Jordana Batista Santana ${ }^{\mathrm{a}, \mathrm{b}}$; Tarcísio Vila Verde S. de Almeida ${ }^{\mathrm{a}, \mathrm{b}}$; Diego Mota Lopesa, ${ }^{\mathrm{a}}$; Luís Eduardo Ribeiro ${ }^{\mathrm{a}, \mathrm{b}}$;Néstor A. Guerrero Gutierrez ${ }^{a, b}$; Edgar M. Carvalho ${ }^{b, d}$ Luciana Santos Cardoso ${ }^{a, b}, c$.

aPrograma de Pós-Graduação em Imunologia, Instituto de Ciências da Saúde (ICS), Universidade Federal da Bahia (UFBA), Salvador, Bahia, Brasil; ' 'Serviço de Imunologia, Hospital Universitário Professor Edgard Santos, HUPES/ UFBA, Salvador, Bahia, Brasil; 'Departamento de Análises clínicas e Toxicológicas, Faculdade de Farmácia, UFBA, Bahia, Brasil; Instituto Gonçalo Moniz, Fundação Oswaldo Cruz, Salvador-BA, Brasild

Introduction: Schistosomiasis is a parasitic disease that affects about 229 million people around the world.During the chronic phase of the disease, fibrosis periportal can occur, which aassociated with a predominantly Th2 type of immune response.Evidences also suggests that Th1 and Th17 lymphocytes are involved in the development of the disease. Objectives: To evaluate the profile of cytokines produced by TCD4+ lymphocytes, and the correlations between these cytokines with wall measurement and diameter of the portal vein. Material and Methods: A total of 29 individualas living in the endemic area for schistosomiasis, classified according degress of periportal fibrosis were recruited.Lymphocyteswereobtained by separation of PBMCs and analyses of surface markers and cytokines were performed by flow cytometry. Results and Discussion: We observed an increase in Th2 cytokines IL-4, IL-5, IL-13, and the regulatory cytokine IL-10 in the group with periportal fibrosiswhen compared to the group without fibrosis or advanced fibrosis. In addition, we observed that all groups of individuals who had some degree of periportal fibrosis present higher frequencyof TGF- $\beta^{+} \mathrm{CD} 4^{+} \mathrm{T}$ lymphocytes, compared with those without fibrosis. Analyzing of the ultrasonography parameters individually e found a significant correlation between the frequencyof TGF- $\beta^{+}$CD4 ${ }^{+}$ T lymphocytesand the measurement of the left lobe and the portal vein wall thickness. We also studied the presence of CD4+ IL17A+ lymphocytes that show and increase in the frequency, however wefound a negative correlation with the portal vein wall thickness. Conclusions: CD4+ T lymphocytes from the group with periportal fibrosis havean increase in the expression of pro-fibrotic cytokines, while higher levels of IL-10, seem to be able to maintain low morbidity in this group.Additionally, the correlation data provide indirect evidence for the role of TGF- $\beta$ and IL-17A and their association with severe forms of schistosomiasis.

Keywords: Schistosomamansoni, Periportalfibrosis, CD4+ T lymphocytes.

Support: FAPESB

\title{
QUANTIFICATION AND COMPREHENSIVE ANALYSIS OF MESENCHYMAL STROMAL CELLS IN BONE MARROW SAMPLES FROM SICKLE CELL DISEASE PATIENTS WITH OSTEONECROSIS
}

\author{
$\underline{\text { Tiago Oliveira Ribeiro }}{ }^{1,2}$; Songeli Menezes Freire ${ }^{1,2}$; VitorAntonio Fortuna ${ }^{1,2}$. \\ ${ }^{1}$ Graduate Program in Immunology, Health Sciences Institute, Federal University of Bahia (UFBA); ${ }^{2}$ Laboratory of \\ Immunology and Molecular Biology, UFBA, Salvador, Bahia, Brazil.
}

Introduction: Osteonecrosis (ON) is a frequent complication of sickle cell disease (SCD) and the implantation of bone marrow mesenchymal stromal cells (BM-MSCs) is currently performed to treat early stages of ON. The efficacy of this therapy depends on thequantity of BM-MSCs to induce bone regeneration. CD271is a cell surface marker that potentially defines a subpopulation of MSC precursors with osteogenic potential. Colony-forming unit assay (CFU) is the conventional method for the quantification of MSCin vitro. Therefore, convenient BM-MSC quantification is a critical factor for cell therapy efficacy. Objectives: The objective of this study was toquantify the MSC population in bone marrow aspirate (BMA) and bone marrow mononuclear cell (BMMC) from SCD patients with osteonecrosis (SCD group) and patients with ostearticular complications not related to SCD (NS group), using flow cytometry for 
CD271+CD45low cell phenotype and CFU-F assay. Materials and Methods: ICS/UFBA ethics committee approved this study [registration number 11738, SIPAR/MS: 25000.039812/2005-99]. $15 \mathrm{ml}$ of BM aspirate was obtained from 22 patients. Bone marrow mononuclear cells (BMMC) were isolated on a Ficoll density gradient. Immunostaining for CD271+CD45low cells and CFU assay were performed to detect and quantify MSC in BM samples. Results and Discussion: The mean total cell number( $96.7 \pm 53.4$ vs $34.8 \pm 15.3$ cells $\times 103$ cells/ $\mu \mathrm{L}, \mathrm{p}<0.001)$ and CFU-F count (1390 [range 15.70 - 7050]vs42.9 [range 12.10 - 73.80])in BMMCwere significantly higher in SCD than NS patients, respectively. A significant correlation between CD271+CD45low cell number and CFU-F counts was found in SCD ( $r=$ $0.7483, p=0.0070)$ and NS $(r=0.7167, p=0.0370)$ BMMC. An age-related quantitative reduction of CFU-F counts and CD271+CD45low cell number was noted. Conclusion: We observed that BM samples from patients with SCDON have a higher frequency of stromal progenitor cells in BMA and BMMC than samples from NS patients. The CD271+CD45low cell counts showed a positive correlation with the number of CFU-Fs in SCD samples.Thus, this work provides important data for the quick measurement of putative BM-MSC in Support to advanced cell-based therapies for SCD patients with osteonecrosis.

Keywords: bone marrow aspirate, mesenchymal stromal cells, osteonecrosis.

Support: Capes, CNPq.

\title{
REVERSE VACCINOLOGY IN MURINE MODEL AND CANINE FOR THE CONTROL OF TOXOCARACANIS INFECTION
}

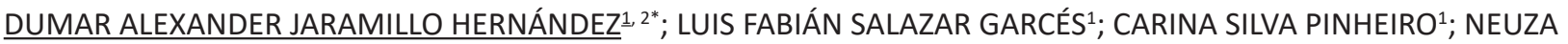 \\ MARIA ALCANTARA-NEVES ${ }^{1}$.
}

1-Institute of Health Sciences (ICS), Federal University of Bahia (UFBA), Salvador, Brazil; 2-College of Animal Sciences, Faculty of Agricultural Sciences and Natural Resources, University of the Llanos, Villavicencio, Colombia; *Postgraduate Program in Immunology, ICS, UFBA, Salvador, Brazil.

Introduction: toxocariasis is a zoonosis of global importance, andhas recently been named one of the five most neglected parasitic infections in the USA by the CDC. Objective: this research applies the methodology of reverse vaccinology in the murine model and canine with the aim of contributing to the control of toxocariasis in canines through immunoprophylaxis. Materials and methods: preclinical studies determined that two recombinant proteins T. canis(rTcVcan and rTcCad) provided significant levels of protection against larval migration in the murine model. These proteins along with three adjuvants (Alhydroge ${ }^{\circledR}$ Th2 profile, PAM3CSK4 ${ }^{\circledR}$ Th1 profile and Quil-A ${ }^{\circledR}$ Th1/Th2 profile)were used for immunization protocol in a murine model of toxocariasis (112 C57black mice); three blood samples were collected at different times of the experiment to measure through indirect ELISA IgA, IgE, IgG (total, IgG1, IgG2a); at the end of the experiment, splecnocytes were cultured to measure cytokines (IL-5, TNF- $\alpha$ and IL-10) in the supernatant, and T. canis larvae were quantifiedintissues.The best protein+adjuvantpair found in the mice experiment ( $r T V$ can+QuialA ${ }^{\circledR}$ ) was used to immunize 24 neonatal canines free-T. canis experimentally infected with $T$. canis. In this first clinical phase study of the toxocariasis vaccine, immunoglobulin curves (IgA, IgE, IgG, IgG1 and IgG2), parasite load (eggs in feces) and cytokines of PBMC cultures (IL-4, IL-10, IL-17A and INFY)were measuredthrough RTPCR. Results and Discussion: $r T V c a n+Q u i a l A^{\oplus}$ presented a highly significant reduction $(p<0.0001)$ of larvae in brain, with a mixed cytokine profile (Th1/Th2) and important anti- $T$. canis antibody titers (IgG, IgG1, IgG2a) in the murine model. In canines it presented a significant reduction in the parasite load $(p<0.05)$ according to the accumulated count of eggs in feces, as well as a significant reduction in adults excreted in feces.The mixed response of Th1/Th2 cytokines with an adequate level of antibodies (IgG) promoted significant protection of mice and canines against toxocariasis under controlled laboratory conditions. Conclusions: this is the first clinical study in the world of a vaccine with recombinant $T$. canisproteins.A vaccine that has shown promising results in the control of canine toxocariasis, where the field of public health and the control of human toxocariasis will surely be positively impacted.

Keywords: Human toxocariasis, immunoprophylaxis, vaccine, zoonosis.

Support: RENORBIO/CNpq grant and extension resource of the Laboratory of Allergy and Acarology of ICS - UFBA. 


\title{
RUTIN INHIBITS GLIAL ACTIVATION AND PROTECTS DOPAMINERGIC NEURONS AGAINST 6-OHDA AND AMINOCHROME CYTOTOXICITY IN ANIMAL MODEL.
}

\author{
ARAÚJO, F.M. ${ }^{1,2}$; FROTA, A.F. ${ }^{2}$; JESUS, L.B. ${ }^{1,2}$; MACEDO, T.C. ${ }^{2}$; SANCHEZ-RODRIGO C. ${ }^{3}$; MENDES, K.M.F. ${ }^{3}$; CUENCA L. ${ }^{3}$; \\ SEGURA-AGUILAR, J. ${ }^{3}$; COSTA, S.L. ${ }^{1,2}$; HERRERO, MT; SILVA, V.D.A. ${ }^{1,2}$. \\ ${ }^{1}$ Postgraduate Program in Immunology, Institute of Health Sciences, Federal University of Bahia, Salvador, Bahia, \\ Brazil. '2Laboratory of Neurochemistry and Cell Biology, Department of Biochemistry and Biophysics, Institute \\ of Health Sciences, Federal University of Bahia, Salvador, Bahia, Brazil. ${ }^{3}$ Clinical \& Experimental Neuroscience, \\ Department of Human Anatomy \& Psychobiology, Institute for Biomedical Research of Murcia (IMIB), School of \\ Medicine, Campus Mare Nostrum, University of Murcia, Murcia Spain
}

Introduction: Parkinson's disease (PD) is a neurodegenerative disorder marked primarily by motor symptoms such as rigidity, bradykinesia, postural instability and resting tremor associated with dopaminergic neuronal loss in the Substantia Nigra pars compacta (SNpc) and deficit of dopamine in the basal ganglia, however the mechanisms responsible for the neurodegeneration remain unknown. Studies have been suggested aminochrome as an endogenous neurotoxin responsible for the dopaminergic neuron degeneration. The aim of this study was to determine glial reactivity induced by aminochrome in an in vivo model of PD and to explore the protective action of flavonoid rutin. Methods and Results: Experimental procedures were sanctioned by the local animal research ethics committee (protocol CEUA -ICS-UFBA- $\mathrm{n}^{\circ}$. 011/ 2017). Wistar rats (male, 250-270g) were divided. in 6 groups (1: saline control,

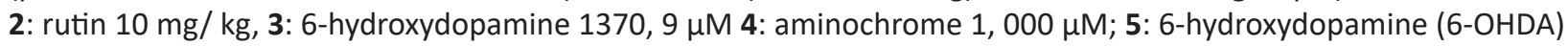
+ rutin and 6: aminochrome + rutin). The animals were orally dosed with rutina 30 minutes before the stereotaxic injection of aminochrome or 6-OHDA in the striatum and daily orally treated with rutin until the 14th experimental day. After euthanasia, the brains were fixed in 4\% PFA, slices were performed in microtome and immunohistochemical analyzes was performed for IBA-1, CD68, GFAP, S100ß and Tyrosine hydroxylase (TH) in the striatum and SNpc. We observed that the aminochrome and 6-OHDA were able to generate increase in the total number of microglia, as well as to increase the quantity of activated microglia evidenced by co-localized IBA- $1^{+} / \mathrm{CD} 68^{+}$cells. It was also observed that astrocyte activation marked by an increase of co-localized $\mathrm{GFAP}^{+} / \mathrm{S}_{100 \mathrm{~S}^{+}}$expression. Dopaminergic neuronal ( $\mathrm{TH}^{+}$cells) loss was also observed in the aminochrome or 6-OHDA-treated groups. On the other hand, rutin presented neuroprotective effect by inhibition effects of aminochrome or 6-OHDA in terms of microglial activation, astrogliosis and dopaminergic neuronal loss. Conclusion: rutin inhibits glial activation and protects dopaminergic neurons against 6-OHDA and aminochrome cytotoxicity. This is the first evidence of glial response in an in vivo model of PD induced by aminochrome. These results improve a new animal model, suggested as a more physiological model of PD and contribute to a development of a new therapeutic agent against neurodegeneration.

Palavras-chave: Parkinson's disease, dopamine, neuroprotection flavonoid.

Support: FAPESB, CAPES, CNPQ and INCT

\section{SCREENING OF MACHINE LEARNING ALGORITHMS FOR THE PREDICTION OF ASTHMA USING GENETIC MARKERS}

Luciano Gama da Silva Gomes; Camila Alexandrina Figueiredo; Álvaro Augusto Souza da Cruz Filho; Ryan dos Santos Costa Institute of Health Science of Federal University of Bahia - UFBA. Salvador/Bahia. Brazil.

Introduction: Asthma is a very heterogeneous chronic inflammatory airway disease.Several genetic variants associated with asthma have been documented in studies of GWAS, but the agreement among studies can be difficult due to the ethnic differences of populations and the complexity of the disease heterogeneity.Advanced artificial intelligence studies are the Key to try to decipher patterns for complex decision making. In this sense, machine learning algorithms are useful tools for predicting complex diseases. Objectives: This study aims to scan some machine learning algorithms to predict asthma and non-asthma and discuss their particularities. Material and Methods: This work is a pilot study in which we used genetic data from subsamples (RORA gene) from a larger genetic bank, which comprises 535 genotyped SNPs (Illumina Multi-Ethic AMR / AFR Kit BeadChip) of individuals 
admitted to the ProAR. All data processing and results generation was performed by $R$. The tested algorithms were the Naive Bayes classifier and the decision tree: C5.0, 1R, and RIPPER. Results and Discussion: Naive Bayes algorithm presented low accuracy of its test prediction (58.50\%) when we used all genectic markers. In this sense, the search for more informative markers for prediction is adequate. The $\mathrm{C} 5.0$ algorithm showed $97.8 \%$ training accuracy, however, its test accuracy drops to $60.89 \%$. At this point, C5.0 signals the main markers used for decision-making. The $1 \mathrm{R}$ algorithm returns only one marker that it considers the best to classify the outcome. Because of this, serial analyzes were performed, and from the second onwards the SNP indicated in the previous analysis was previously removed. Of these results, three SNPs shared the findings by C5.0: rs1550225, rs140827468, and rs72750685. There were no similarities in decision-making between sequential $1 R$ analisis and RIPPER. We returned to the analysis with Naive Bayes, however, using only the three SNPs taken together. We observed that the accuracy of the prediction was $73.13 \%$.Conclusion: Algorithms work differently, but they can jointly signal genetic markers that can become the focus of other studies.

Keyword: asthma, Machine Learning, prediction, SNP

Support: CNPq.

\title{
SEROPREVALENCE OF CASEOUS LYMPHADENITIS IN SMALL RUMINANTS AT SLAUGHTERHOUSE FROM THE STATE OF BAHIA.
}

\author{
Caio Lopes Borges Andrade ${ }^{1,2}$, Ramon Mendes dos Santos ${ }^{1,2}$, Rogério Reis Conceição $0^{1,2}$, Hévlyn Ribeiro de Araújo ${ }^{1,3}$, \\ Maria Isabel Cerqueira ${ }^{1,3}$, Marcos Borges Ribeiro ${ }^{1}$, Roberto José Meyer Nascimento ${ }^{1}$, Songelí Menezes Freire ${ }^{1,4}$ \\ ${ }^{1}$ Laboratório de Imunologia e Biologia Molecular (LABIMUNO), Instituto de Ciências da Saúde, Universidade Federal \\ da Bahia; '2Programa de Pós Graduação em Imunologia.
}

Introduction: Corynebacterium pseudotuberculosis is a gram-positive pleomorphic bacillus, macrophage facultative intracellular pathogen, which commonly affects ruminants, being responsible for Caseous Lymphadenitis (LC) in goats and sheep. This disease with an endemic character, is widespread in herds throughout Brazil and causes economic losses for producers. Animal diagnosis is relatively simple. However, the treatment and control of LC has low effectiveness. Bacteriological culture from the caseous content, followed by biochemical tests is currently the gold standard. According to data from the Instituto Brasileiro de Geografia e Estatística (IBGE), more than $90 \%$ of goat population and $60 \%$ of sheep population in Brazil are concentrated in the Northeast region, with emphasis on Bahia and Pernambuco, these herds are mainly intended for the production of meat and leather. As they receive herds from different regions of the state, slaughterhouses represent a crucial point for assessing large contingents from different properties. Objectives: Identify the degree of contamination of slaughtered sheep and goats in the state of Bahia. Methods: Information on the origin and characteristics of the animals will be recorded during their arrival at the slaughterhouse and before sample collection. With the help of the slaughterhouse staff, samples of blood and necropsy of lymph nodes with alterations will be collected from goats and sheep in the slaughter line. Serum from blood samples will be recovered and an ELISA performed to identify individuals with antibodies to $C$. pseudotuberculosis antigens. Samples with results very close to the cutoff will be confirmed by Wersten Blotting. From the altered lymph nodes, bacterial isolation and identification of possible strains of $C$. pseudotuberculosis will be performed. Generated data will be cataloged and analyzed statistically using Microsoft Excel and Prism-GraphPad. Expected Results: Describe the distribution and geographic density of $C$. pseudotuberculosis in the state of Bahia, obtaining a better understanding of the distribution of LC in goat and sheep herds slaughtered in Bahia.

Keywords: Corynebacterium pseudotuberculosis, Caseous Lymphadenitis, Slaughterhouses

Support: Universidade Federal da Bahia (UFBA), Laboratório de Imunologia e Biologia Molecular (Labimuno-UFBA), Fundação de Apoio à Pesquisa e à Extensão (FAPEX), Coordenação de Aperfeiçoamento de Pessoal de Nível Superior (CAPES), Agência de Defesa Agropecuária da Bahia (ADAB), Ministério da Agricultura Pecuária e Abastecimento da Bahia (MAPA-BA). 


\title{
SKELETAL MUSCLE INJURY INDUCED BY BOTHROPSLEUCURUS VENON AND TISSUE REPAIR: INFLAMMATORY PROFILE AND MECHANISMS INVOLVED
}

\author{
Clara Macêdo Mimoso ${ }^{1}$, Kaenna Baraúna Campos ${ }^{1}$, Simone Garcia Macambira ${ }^{1,2,3}$, Luciana Lyra Casais-e-Silva ${ }^{1,4}$ \\ ${ }^{1}$ Programa de Pós Graduação em Imunologia - Instituto de Ciências da Saúde/Universidade Federal da \\ Bahia. ${ }^{2}$ Departamento de Bioquímica e Biofísica - Instituto de Ciências da Saúde/Universidade Federal da \\ Bahia. ${ }^{3}$ Laboratório de Engenharia Tecidual e Imunofarmacologia - Instituto Gonçalo Moniz/FIOCRUZ/Bahia. \\ ${ }^{4}$ Departamento de Biorregulação, Laboratório de Neurolmunoendocrinologia e Toxinologia (LABNIET) - Instituto de \\ Ciências da Saúde/Universidade Federal da Bahia
}

Introduction: Snakebite envenoming is an important public health problem in tropical regions of the world, due to the number of people affected and the risk of morbidity and mortality.In Brazil, about $90 \%$ of snake accidents are caused by Bothrops genus, which envenoming is characterized by systemic alterations (i.e. coagulation disorders, hemorrhage and nephrotoxicity, the main cause of death) and local damage (i.e. persistent inflammation, tissue damage and myonecrosis). In Bahia, Bothropsleucurusspecie is the main etiological agent. Although antivenom serotherapy is effective in neutralizing systemic effects, the local effects are poorly neutralized, causing irreversible tissue damage. Objectives: Characterize the tissue injury evolution and repair development after venom inoculation in skeletal muscle, determining (i) process time course, (ii) tissue functional and structural impairment and (iii) inflammatory mediators involved in tissue lesion and repair. Methods: Swiss mice will be inoculated into the gastrocnemius muscle with $50 \mu \mathrm{g} / \mathrm{mL}$ of the total venom. Muscle damage will be assessed by measuring serum creatine kinase at different experimental times ( 3 and $6 \mathrm{~h}, 1,3,7,14$ and 28 days). Before the inoculation of the venom and during the experimental times, the animals will be submitted to treadmill test and euthanized for histological analysis of the gastrocnemius muscle. The total and differential leukocyte count will be performed using Neubauer's chamber and specific staining, respectively. Muscle fibers will be quantified in the cryopreserved muscle, by immunofluorescence analysis, and the measurement of cytokines will be performed in the serum by ELISA technique. Results and Discussion: The results of this research will expand knowledge about the inflammatory response to venom that leads to tissue injury and repair, through immunomodulatory mechanisms characterization, improving the regionalized studies for this species. Conclusions: These studies will contribute to elucidate the pathogenesis of inflammation and local necrosis triggered by this venom, in addition to providing information for the development of therapeutic strategies in the management of local injuries due to poisonous snake bites, acting as an adjunct to antivenom serotherapy.

Keywords: Venom; Bothrops; Myotoxicity; Inflammation.

Support: FAPESB.

\section{STUDY OF GLIAL RESPONSE IN A NEW IN VITRO MODEL OF CEREBELLAR CELL CULTURE}

\author{
Santana, L. F, Santos, C. C, Ferreira, R. S, Ameida, A. M. A. N, De Castro, M. V. L, Franchi, M. S, Andrade, G. B, Da \\ Silva, T. M, Costa, S. L* and Silva, V. D. A* \\ ${ }^{1}$ Laboratory of Neurochemistry and Cell Biology, Department of Biochemistry and Biophysics, Institute of Health \\ Sciences, Federal University of Bahia, Salvador, Bahia, Brazil. ${ }^{2}$ Postgraduate Program in Immunology, Institute of \\ Health Sciences, Federal University of Bahia, Salvador, Bahia, Brazil.
}

Introduction: Communication between glial cells and neurons modulate the pattern of neuroinflammatory response. Astrocytes and microglia, are immuno-effector cells in the Central Nervous System (CNS), when they suffer insult they become activated and add neuroprotective or neurotoxic response profiles of type A1-A2 / M1-M2. Objectives: In this study, we evaluated the pattern of glial response after inflammatory induction with LPS in a new model of primary cerebellar cell culture. Methods: We used primary cerebellar culture, grown in a medium supplemented with growth factors B27, bFGF, Insulin, PDGF-AA and factors released in the conditioned medium, later exposed to LPS and neuron integrity analyzes by staining with Fluoro Jade B (FJB) ) and immunocytochemistry for $\beta$-TubllI neurons, GFAP astrocytes and Iba1 microglia markers. Results and Discussion: It was observed that LPS induced neurodegeneration characterized by an increase in $\mathrm{FJB}^{+}$cells and loss of $\beta$-Tublll expression, activation of the glial response by increasing the percentage of $\mathrm{GFAP}^{+}$and $\mathrm{Iba}^{+}$cells, as well as morphological changes. Conclusions: Thus, we suggest the new 
study model as a useful tool to study neurodegenerative diseases associated with neuroinflammation, since we characterize an evident glial response to the inflammatory stimulus induced by LPS and evident neuronal loss.

Keywords: Neuroinflammation, invitrostudymodel, glia, cerebellum.

Support: FAPESB, CAPES, CNPq.

\title{
STUDY OF THE FLAVONOID RUTIN EFFECT ON ANTI-INFLAMMATORY AND ANTIVIRAL RESPONSES IN DIFFERENT BRAIN REGIONS DURING DEVELOPMENT.
}

\author{
$\underline{\text { Rosimére Oliveira Torres }}^{1}$, Silvia Lima Costa and ${ }^{1}$ Clarissa de Sampaio Schitine ${ }^{1}$ \\ ${ }^{1}$ Laboratory of Neurochemistry and Cell Biology, Department of Biochemistry and Biophysics, Institute of Health \\ Sciences, Federal University of Bahia, Salvador, Bahia, Brazil.
}

Introduction: Neurogenesis is a constitutive process that occurs in two main regions: the subventricular zone (SVZ) of the lateral ventricle and the subgranular zone (SGZ) of the hippocampal dentate gyrus (DG). The subventricular zone (SVZ) generates neurons that migrate through the rostral migratory current (RMS) to the olfactory bulb (OB) to act as interneurons. Anomalies in the processes of cell proliferation, migration and differentiation may be involved with the emergence of neurodegenerative diseases. In addition, the recent coronavirus pandemic outbreak (COVID-19) poses an important and urgent threat to global health. In addition to the systemic symptoms caused by COVID19, many patients develop severe neurological symptoms. And how the long-term consequences of neurological damage of an inflammatory nature contributes to the development of neurodegenerative diseases are largely unknown. Flavonoids are polyphenolic compounds that can reduce inflammation, promote cognition prevent cancer andpromote antiviraleffects. The flavonoid rutin participates in the activation of cascades of neuroprotection and differentiation, and has functions in the regulation of cell proliferation and differentiation events in models of neurogenic niches, being possible pro-cognitive candidates and potential therapeutic agents for oxidative and neurodegenerative processes. In addition, it has antiviral effects, so rutin is a strong candidate for prospecting antiviral drugs including the new coronavirus. Objectives: To evaluate the effect of $f$ rutin on cell proliferation, differentiation, and its influence on astrocytic and microglial reactivity, cell viability, using specific markers, and measuring inflammatory response indicators in control, under excitotoxicity stimulation, and preclinical models of SARS- CoV-2 infection. Material and Methods: Our study model involves cell cultures from different brain regions (cortex, SVZ, and hippocampus), preparedfromC57BL / 6 mice. The cultures will be carried out at different developmental stages embryonic, postnatal, and adult animals. Expected results: characterization of the rutin functions on cell proliferation and differentiation.in culture models of SVZ, cortex, and organotypic cultures of the hippocampus at different stages of development and its anti-inflammatory, antioxidant mechanisms, as well as its possible antiviral activity for clinical strategy proposals against different neuropathologies including SARS-CoV-2 infection.Keywords: Neurogenesis; rutin; SARS-CoV-2. Support: Capes.

\section{STUDY OF THE MOLECULAR MECHANISMS ASSOCIATEDWITH ANTIGLIOMA AND IMMUNOMODULATORY EFFECTS OF FLAVONOIDS RELATEDTO INTERACTION WITH AHR}

\author{
Monique Reis de Santana ${ }^{1}$, Ravena Pereira do Nascimento ${ }^{1}$, David Gilot ${ }^{2}$, Silvia Lima Costa ${ }^{1}$ \\ ${ }^{1}$ Programa de Pós-Graduação em Imunologia, Instituto de Ciências e Saúde (ICS), Laboratório de Neuroquímica e \\ Biologia Celular, Universidade Federal da Bahia (UFBA), Bahia, Brazil; ${ }^{2} N S E R M ~ U 1242$, Université Rennes 1, France.
}

Introduction: Glioblastoma (GBM)is the most common and aggressive neoplasm in the primary brain tumor, presenting high cell proliferation, with infiltrative and invasive characteristics, that favors these tumor to have a great recurrence after treatment. Many mechanisms potentially involved in the tumor recurrence have been described, and between them the BRAF-V600E mutations have been associated to tumorigenesis and most commonly found in brain tumors such as GBM. Recently, BRAF mutation was identified as a marker for a small subset of infiltrating gliomas in adultsand appears to be related to chemo and immunoresistance. Moreover, a study demonstrated that 
the transcription factor arylhydrocarbon receptor $(A h R)$ is constitutively activated in tumor cells, promoting the differentiation of melanoma cells and increased expression of BRAF I resistance genes, putting AhR antagonism as a target in cancer chemotherapy. The anti-tumor potential of flavonoids and the anti-inflammatory activity in human glioma cells has been investigated and the pharmacological potential of these drugs have encouraged studies in alternative therapy for malignant gliomas. Objectives: This study aims to better define the antitumor mechanisms of flavonoids and association of its antiglioma activity with the capacity to acts as AhRantagonists. Material and Methods: Natural flavonoids, whose anti-glioma effects have already been demonstrated, will be tested as ligands of $A h R$, and the more actives in AhR selectivity will be chose to investigate effects during microglia/GBMcells interaction by using methodological approaches in the field of cell and molecular biology, based on cell culture models. Expected Results: The characterization of the molecular mechanismsof flavonoids is expected at the end of this study, featuring a possible antagonistic effect on AhR and its role in chemosensitivity, to sustain their application as adjuvant for GBM treatments.

Keywords: glioma; flavonoids;AhR, immunomodulation; microglia

Support: CAPES, CNPq e FAPESB

\title{
STUDY OF VARIANTS IN THE IL17 GENE IN DIFFERENT PEDIATRIC ASTHMA ENDOPHENOTYPES, INCLUDING GLUCOCORTICOID RESISTANT ASTHMA.
}

\author{
Saulo Ferreira de Assis, Laura Maria de Lima, Belizario Facury Lasmar, Ryan dos Santos Costa. \\ Departamento de Biorregulação, Laboratório de Imunofarmacologia e Biologia Molecular (IMUNOBIO) - Instituto \\ de Ciências da Saúde da Universidade Federal da Bahia (ICS/UFBA). Centro Multidisciplinar de Asma de Difícil \\ Controle (CEMAD) da Universidade Federal de Minas Gerais (UFMG).
}

Introduction: Asthma is a chronic disease that presents heterogeneity in clinical and functional aspects, being characterized by inflammation of the lower airways whose development depends on the interaction between environmental and genetic factors. Usually, asthma symptoms are well controlled with medium or low doses of inhaled corticosteroids, but approximately $5 \%$ of asthmatics do not have a good response, requiring high doses of inhaled corticosteroids in addition to associations with other drugs to obtain or not clinical control. Among patients with severe asthma, approximately $10 \%$ of them, although using high doses of inhaled corticosteroids associated with a second controlling drug, are unable to obtain clinical control. Objectives: The aim of this study is to investigate the association of variants of the IL17 gene with the different pediatric asthma endophenotypes, including glucocorticoidresistant asthma. Material and Methods: The study population includes individuals with severe asthma, severe refractory asthma, mild asthma and healthy controls who will be evaluated for clinical parameters, lung function, atopy markers, response to glucocorticoid treatment, among others. The polymorphisms in the IL17A and IL17F gene will be genotyped. Results and Discussion: Preliminary results from nine patients, among them, four with severe uncontrolled asthma and five with severe controlled asthma showed that there is a relationship between SNP rs3819024 for IL-17th with the severity of asthma. Conclusions: Therefore, the study will advance the understanding of the inter-individual variability of asthma.

Keywords: IL17, severe asthma, resistance to glucocorticoids.

Support: This project is an integral part of the project "Study of the association of the level of expression of IL17-A and variants in its gene with the different asthma phenotypes, including glucocorticoid-resistant asthma"

Support: by the EDP PROPCI / PROPG - UFBA 004/2016. 


\title{
THE FLAVONOID AGATHISFLAVONE MODULATES MICROGLIAL ACTIVATION AND PRESENTS NEUROPROTECTIVE EFFECTS IN VITRO MODEL OF NEUROINFLAMMATION.
}

\author{
Balbino Lino dos Santos ${ }^{1,2}$, Cleonice Creusa dos Santos ${ }^{1}$, Victor Diogenes Amaral da Silva ${ }^{1,3}$, Silvia Lima Costa ${ }^{1,3,4^{*}}$ \\ ${ }^{1}$ Laboratory ofNeurochemistryandCellularBiology, Instituteof Health Sciences, Av. Reitor Miguel Calmon S/N, \\ Federal University of Bahia (UFBA), Salvador, Brazil, ${ }^{2}$ College ofNursing, Federal Universityof Vale do São Francisco \\ (UNIVASF), Petrolina, Brazil, ${ }^{3}$ INCT for ExcitotoxicityandNeuroprotection (INCT-EN, BR), Porto Alegre, Brazil, \\ ${ }^{4}$ Instituto Nacional de Ciência e Tecnologia em Excitotoxicidade e Neuroproteção (INCT)-TranslationalNeuroscience
} (INCT-TN, BR), Porto Alegre, Brazil.

Introduction: Neuroinflammation is one of the mechanisms responsible for the emergence of neurodegenerative diseases, as it acts by interfering with the morphology and activation of CNS cells, with emphasis on the inflammatory profile assumed by the microglia, and the neural damage caused by its inflammatory mediators. Some classes of flavonoids extracted from plants have shown anti-inflammatory effects in in vitro and in vivo models of studies. Objectives: Here, we studied the anti-inflammatory and immunomodulatory effect of agathisflavona, a flavonoid derived from Poincianellapyramidalis (Tul.), in a model of neuroinflammation induced by lipopolysaccharide (LPS), in primary microglia cultures. Results and Discussion: we observed that the inflammatory stimulus with LPS induced the primary microglial culture to assume an activated cellular state with an inflammatory profile characteristic of M1 (increase in CD68 - inflammatory marker), confirmed by the phenotypic changes with rounder or amoeboid cells. However, when treated with agathisflavona, there was positive regulation of CD206 (anti-inflammatory marker M2) and negative regulation of $\mathrm{CD68}$, as well as proliferation and prevalence of more branched-looking microglia, thus demonstrating the tendency of cells to assume a anti-inflammatory state. Conclusions: Thus, these data reinforce the anti-inflammatory activity of flavonoid, highlighting it as a promising molecule for the treatment or prevention of neurodegenerative diseases.

Keywords: Neuroinflammation, Neuroprotection, Anti-inflammatory, Flavonoids.

Support: CAPES

\section{THE GLUCOCORTICOID RECEPTOR CONTRIBUTES TO REDUCTION OF LPS-INDUCED GLIAL REACTIVITY IN VITRO BY AGATHISFLAVONE}

\author{
Áurea Maria Alves Nunes Almeida ${ }^{1}$, Cleonice Creusa dos Santos ${ }^{1}$, Gloriene Carvalho de Jesus ${ }^{1}$, Larissa Pedreira da \\ Silva ${ }^{1}$, Verônica Moreira de Souza ${ }^{1}$, Ana Elisa Del'Arco Vinhas Costa ${ }^{1}$, Balbino Lino dos Santos ${ }^{1}$, \\ Victor Diógenes Amaral da Silva ${ }^{1}$, Suzana Braga de Souza ${ }^{1}$, Silvia Lima Costa ${ }^{1}$ \\ 'Laboratory of Neurochemistry and Cell Biology, Department of Biochemistry and Biophysics, Institute of Health \\ Sciences, Federal University of Bahia, Salvador, Bahia, Brazil.
}

Introduction: Neuroinflammation is a characteristic of neurodegenerative diseases, resulting from the release of proinflammatory molecules by glial cells. The co-occurrence of chronic dysregulation of inflammatory and stress responses in neurodegenerative and psychiatric disorders suggests the participation of the glucocorticoid receptor $(G R)$ in the etiology of neurodegeneration. The biflavonoid agathisflavone is an apigenin dimer, with neurogenic, neuroprotective and anti-inflammatory actions demonstrated in in vitro models of glutamate-induced toxicity, neuroinflammation and stroke. In previous studies, our group demonstrated that agathisflavone mediates neuroprotection against glutamate excitotoxicity via estrogen receptor, a transcription factor sharing structural and functional properties with glucocorticoid receptor the mechanisms mediating agathisflavone action are still poorly understood. Objectives: The aim of this study was to investigate whether the anti-inflammatory action of agathisflavone is mediated by GR. Methods: An in vitro model of lipopolysaccharide (LPS; $1 \mu \mathrm{g} / \mathrm{mL}$ ) induced neuroinflammation was performed in primary cultures of astrocytes and microglia from the cortex of neonatal Wistar rats. Cells were treated with LPS, in association or not with agathisflavone $(1 \mu \mathrm{M})$, in the absence or presence of mifepristone (RU486; 1 $\mu \mathrm{M})$, a GR antagonist. The cytotoxicity of these substances in this in vitro model was evaluated by the MTT assay. Glial reactivity, an indicator of inflammatory profile, was evaluated by immunocytochemistry against astrocyte and 
microglia markers, GFAP and Iba-1, respectively. Cell proliferation was evaluated by immunocytochemistry against bromodeoxyuridine (BrdU). Results: No decrease in mitochondrial activity was caused by the substances tested in the MTT assay, suggesting they are not cytotoxic in the tested concentration ranges. Astrocyte proliferation and relative GFAP expression increased in response to LPS treatment, but not in response to co-treatment with agathisflavone and/or RU486. Microglial proliferation was reduced following treatment with both LPS and agathisflavone, which was inhibited in the presence of RU486. These results suggest that agathisflavone modulates microglial proliferation via GR after inflammatory stimulation. The mechanisms of agathisflavone action would be further elucidated by studies characterizing the molecular and gene expression profile of glial cells.

Keywords: neuroinflammation, glucocorticoid receptor, microglia, astrocyte, Agathisflavone, neuroprotection.

Support: FAPESB (INT 016/2016 APP.107/2016): CAPES (PGCI Proc. - 88881.117666/2016-01); INCT Nacional Institute for Translational Neuroscience and INCT for Excitotoxicity and Neuroprotection (MCTI/CNPq).

\title{
THE USE OF TUMOR ANTIGENS IN THE IMMUNIZATION OF ANIMALS CHRONICALLY INFECTED WITH TRYPANOSOMA CRUZI PREVIOUSLY TREATED WITH ADJUVANTS
}

\author{
Amanda Silva $^{1-2}{ }^{1}$ Davi Salles ${ }^{1}$, Maiara Bonfim ${ }^{1-2}$, Jose Menge ${ }^{3-4}$, Fabiola Cardillo ${ }^{1}$. \\ ${ }^{1}$ Gonçalo Moniz ResearchInstitute. Oswaldo Cruz Foundation, LAPEM, Salvador-Ba, Brasil. ${ }^{2}$ Federal Universityof \\ Bahia (UFBA), PPGIm, Salvador-Ba, Brazil. ${ }^{3}$ Oswaldo Cruz Foundation, Oswaldo Cruz Institute, Fiocruz, Rio de \\ Janeiro, Brazil. ${ }^{4}$ Faculty of Medicine of Petrópolis, FMP-FASE, Petrópolis, Rio de Janeiro
}

Introduction: Infection with Trypanosoma cruzi (T. cruzi) is associated with unregulated autoimmunity and severe tissue damage. The disease usually presents an initial acute phase, followed by an indeterminate or a chronic phase. Objectives: This investigation aimed to analyze whether the associated administration (or not) of alpha-tocopherol or tumor antigens (ags) modulate the tissue damage found in muscles of animals chronically infected with Trypanosoma cruzi. Besides, this study is to verify if tumor antigens could induce immunosuppression to regulate immune responses. Methods: Mice were immunized with $T$. cruziags adsorbed in alpha-tocopherol or $\mathrm{Al} 3 \mathrm{OH}$ and infected with T.cruzi. Then, mice were also immunized with melanoma B16F0ags. Splenocytes were cultured with (or without) Concanavalin A (Con A). T cells were stained for intracellular cytokines (IFNY, IL10) and membrane LAP labeling. In all experimental groups, inflammatory infiltrates in the heart, and skeletal muscles were evaluated by histopathological analysis. Results: Chronically infected animals previously treated only with alpha-tocopherol presented lower inflammation in striated and skeletal muscles infiltrates than untreated chronically infected animals $(p=0,0286$, Mann Withney test, $n=4)$. These results were similar when 50 or 1000 forms of $T$. cruziwere used for the infection. Subsequently, after alpha-tocopherol immunization and injection with B16F0ags, results indicated immunomodulation that is probably related to a nonspecific immune response, because of the previous treatment with alpha-tocopherol. A decrease in $\mathrm{CD}^{+}$and $\mathrm{CD}^{+} \mathrm{T}$ cells producing IFN $\gamma$, IL10, and LAP were observed ex vivo, after Con A stimulation. Contrarily, chronically infected animals that did not receive alpha-tocopherol previously (but were immunized with the B16F0ags) had higher percentages of cytokine-producing T cells compared to animals without alpha-tocopherol injection. After B16F0ags injection, inflammatory infiltrates in striated or skeletal muscles were not different between the experimental groups evaluated. Conclusion: Chronically infected mice that received alpha-tocopherol before the injection of B16FOags lead to the establishment of a regulated immune response. After the injection of B16F0ags, in the absence of the previous alpha-tocopherol in chronic mice, cytokine levels were increased upon Con A stimulation of splenocytes.

Keywords: Trypanosoma cruzi, adjuvant effect, melanoma antigens, immunomodulation.

Support: by PAPES-CNPq (proc.407752/2012-9). AS and DS are respectively MSc and Pibic FAPESB. MB is MSc CAPES, fellowships. 


\title{
ZIKA VIRUS SINGULAR PEPTIDE PRODUCTION FOR THE DEVELOPMENT OF SEROLOGICAL IMMUNOASSAYS AND EVALUATION OF IMMUNE RESPONSE
}

\author{
Rafael Ribeiro Mota Souza' ${ }^{1}{ }^{3}$, Isabela Brandão Peixoto', Rejane Hughes Carvalho', ${ }^{2}$, Gubio Soares Campos', Roberto \\ José Meyer Nascimento ${ }^{3}$, Silvia Ines Sardi ${ }^{1}$ \\ ${ }^{1}$ Laboratory ofVirology, Health Science Institute, Universidade Federal da Bahia, Brazil. ${ }^{2}$ Gonçalo Moniz Institute \\ (FIOCRUZ), Bahia, Brazil. '3aboratory ofImmunologyand Molecular Biology, Health Science Institute, Universidade \\ Federal da Bahia, Brazil, Brazil;
}

Introduction: The rapid spread of Zika virus (ZIKV) in endemic regions where other Flaviviruses have already been established, such as Dengue Virus (DENV), has led to difficulties in accurately diagnosing the infectious agent. Both Flaviviruses present very similar acute symptomatic conditions and high similarity among their viral proteins, what leads to serology cross-reactions between Zika and Dengue, producing false positive results. In addition, studies have demonstrated that antibody-dependent enhancement also increase viremia due to the cross-reaction between the tests. Objectives: Based on the demand for more specific antigens, the present project aims to produce non cross-reactive ZIKV antigens for immunodiagnostic and immunomodulation in vivo. Material and Methods: Unique epitopes were indentified using bioinformatic tools to analyse amino acids conservance (EBI-MUSCLE-MSA ; Jalview), their similarity (BLASTp/NCBI), and antigenicity (IEDB ; CHIMERA (UCSF)). The production of ZIKV unique antigens was planned and performed on a plamid construction derived from the bioinformatic investigation. Plasmids used in BL21 Star transformation for expression under addministration of IPTG. Results and Discussion: As preliminary results, bioinformatics analysis identified 3 unique and immunogenic epitopes derived from ZIKV proteins; one from the $E$ protein and two from the NS1. The coding region for the E epitope was used to construct an expression vector containing four in tandem uninterruptedly repetitions of the sequence. The other expression vector was constructed using the two sequences from the NS1 protein. Those two regions were placed in a 3 and 2 intercalated repetition manner. Both vectors were cloned in E. coli and were expressed (confirmed by western blot against histag). Future experiments include the evaluation of sensitivity and specificity of the antigens using Dengue and Zika IgG+ sera by ELISA and Western Blot, and the evaluation of humoral immune response in BALB / c mice. Conclusion: Overall, the investigation of the ZIKV epitopes based on previous bioinformatic analysis could lead to the elaboration of new tools for immunodiagnosis, provaiding a more accuretedstategies to the survaillance of ZIKV.

Keywords: Zika virus, immunodiagnostic, bioinformatics.

Support: Gonçalo Moniz Institute (FIOCRUZ), 
Fundada em 2002, a Revista de Ciências Médicas e Biológicas é editada pelo Instituto de Ciências da Saúde da Universidade Federal da Bahia e tem por objetivo publicar, quadrimestralmente, os resultados de pesquisas originais que venham a contribuir para o desenvolvimento do conhecimento científico e tecnológico nas áreas médica, bioética e biológica.

Baseada em recomendação do Conselho Editorial e/ou de consultores ad hoc, publica trabalhos científicos em português, inglês, francês e espanhol relativos a todas as áreas do conhecimento médico e biológico e áreas correlatas, sob a forma de artigos originais, artigos de divulgação, artigos de revisão, casos clínicos, conferências e resenhas.

Founded in 2002, The Journal of Medical and Biological Sciences is published by the Institute for Health Sciences of the Federal University of Bahia. It aims at publishing three times a year the results of original researches which may contribute to the development of the scientific and technological knowledge within the medical, bioethical and biological fields.

Based on the recommendations of its Editorial Committee and/or ad hoc consultants, the Journal publishes scientific articles in Portuguese, English, French and Spanish concerning all medical and biological areas, as well as their correlated fields, presented as original articles, articles of partial results, overviews, clinical cases, lectures and reviews. 


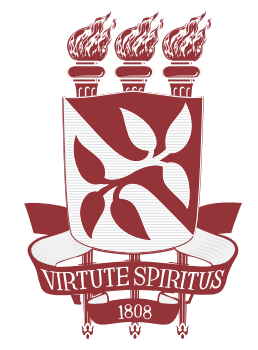

Universidade Federal da Bahia Instituto de Ciências da Saúde Av. Reitor Miguel Calmon $\mathrm{s} / \mathrm{n}^{\mathrm{o}}$ 40.110-100 Salvador, BA - Brasil 